\title{
Preclosure Analysis of Conceptual Waste Package Designs for a Nuclear Waste Repository in Tuff
}

\author{
W. C. O'Neal, D. W. Gregg, \\ J. N. Hockman, E. W. Ruseell, and W. Stein \\ Manuscript date: November 1, 1984
}

\begin{abstract}
DISCLAMMER

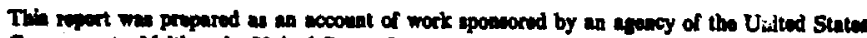
Govoriment. Newthar the Unilud States Goversment sox any anecy thereof, nor any of their

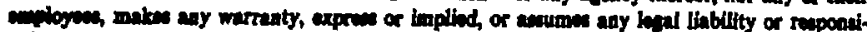

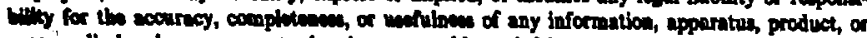

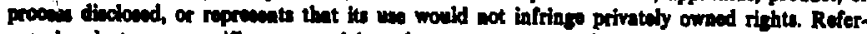

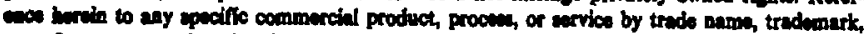

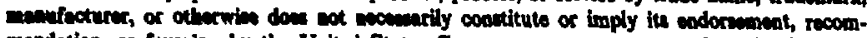

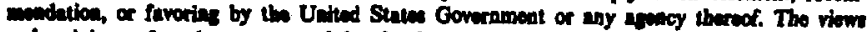

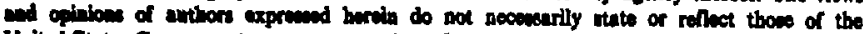

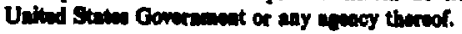

\section{LAWRENCE LIVERMORE NATIONAL LABORATORY University of California - Livermore, California $\cdot 94550$}




\section{Contents}

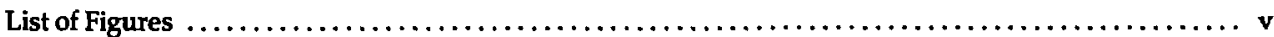

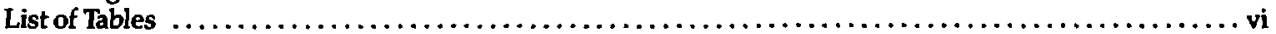

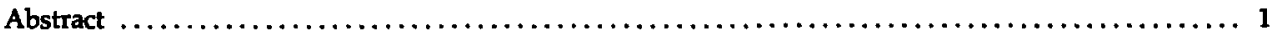

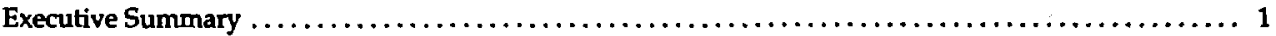

Section I. Conceptual Waste Package Designs $\ldots \ldots \ldots \ldots \ldots \ldots \ldots \ldots \ldots \ldots \ldots \ldots \ldots \ldots \ldots \ldots \ldots, 8$

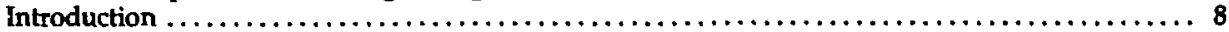

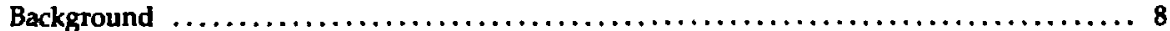

Waste Forms and Quantities $\ldots \ldots \ldots \ldots \ldots \ldots \ldots \ldots \ldots \ldots \ldots \ldots \ldots \ldots \ldots \ldots \ldots \ldots \ldots$

Repository Location and Waste Package Environment $\ldots \ldots \ldots \ldots \ldots \ldots \ldots \ldots \ldots \ldots, \ldots$

Waste Package Emplacement Configurations $\ldots \ldots \ldots \ldots \ldots \ldots \ldots \ldots \ldots \ldots \ldots \ldots \ldots \ldots \ldots$

Waste Package Conceptual Design Selection Philosophy $\ldots \ldots \ldots \ldots \ldots \ldots \ldots \ldots \ldots \ldots \ldots \ldots 12$

Alternative Designs That Have Been Eliminated $\ldots \ldots \ldots \ldots \ldots \ldots \ldots \ldots \ldots \ldots \ldots \ldots \ldots \ldots \ldots$

Regulatory Requirements for Waste Package Design $\ldots \ldots \ldots \ldots \ldots \ldots \ldots \ldots \ldots \ldots \ldots \ldots \ldots \ldots \ldots$

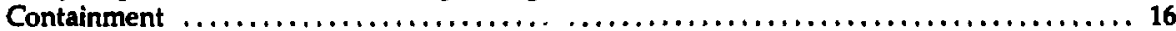

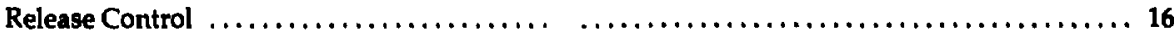

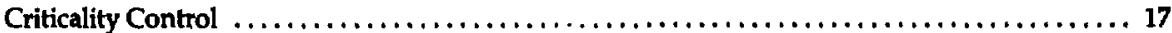

Retrievability of Waste $\ldots \ldots \ldots \ldots \ldots \ldots \ldots \ldots \ldots \ldots \ldots \ldots \ldots \ldots \ldots \ldots \ldots \ldots \ldots \ldots \ldots$

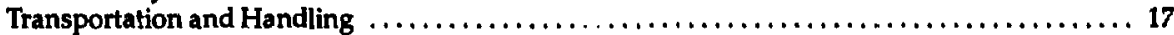

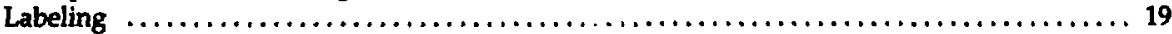

Desirable Design Features $\ldots \ldots \ldots \ldots \ldots \ldots \ldots \ldots \ldots \ldots \ldots \ldots \ldots \ldots \ldots \ldots \ldots \ldots \ldots \ldots \ldots$

Conceptual Waste Package Configurations and Dimensions $\ldots \ldots \ldots \ldots \ldots \ldots \ldots \ldots \ldots \ldots \ldots \ldots \ldots$

Conceptual Waste Package Designs for Spent Fuel $\ldots \ldots \ldots \ldots \ldots \ldots \ldots \ldots \ldots \ldots \ldots \ldots \ldots 20$

Conceptual Waste Package Designs for Commercial High Level Waste $\ldots \ldots \ldots \ldots \ldots \ldots \ldots \ldots$

Conceptual Waste Package Designs for West Valley/[Lfense High Level Waste $\ldots \ldots \ldots \ldots \ldots .24$

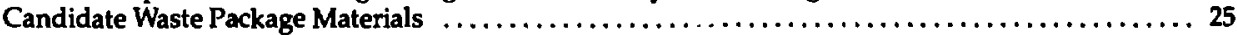

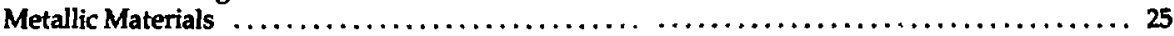

Nonmetallic Waste Package Packing Material $\ldots \ldots \ldots \ldots \ldots \ldots \ldots \ldots \ldots \ldots \ldots \ldots \ldots$

Section II. Information Required to Demonstrate Regulatory

Compliance by the Conceptual Waste Package Designs $\ldots \ldots \ldots \ldots \ldots \ldots \ldots \ldots \ldots \ldots \ldots \ldots \ldots \ldots 28$

Selection of Candidate Waste Package Containment Barrier

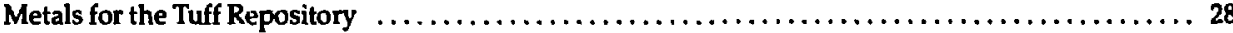

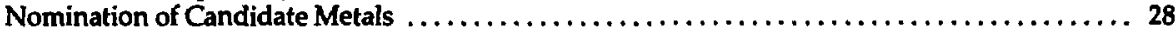

Summary of Candidate Alloys $\ldots \ldots \ldots \ldots \ldots \ldots \ldots \ldots \ldots \ldots \ldots \ldots \ldots \ldots \ldots \ldots \ldots \ldots$

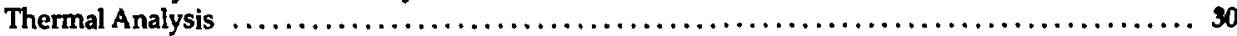

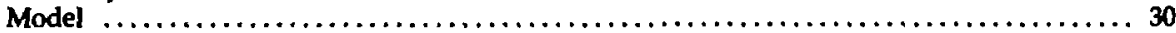

Vertical Emplacement $\ldots \ldots \ldots \ldots \ldots \ldots \ldots \ldots \ldots \ldots \ldots \ldots \ldots \ldots \ldots \ldots \ldots \ldots \ldots \ldots \ldots \ldots, 31$

Horizontal Emplacement $\ldots \ldots \ldots \ldots \ldots \ldots \ldots \ldots \ldots \ldots \ldots \ldots \ldots \ldots \ldots \ldots \ldots \ldots \ldots \ldots \ldots \ldots \ldots, 32$

Effects of Packing on Waste Temperature $\ldots \ldots \ldots \ldots \ldots \ldots \ldots \ldots \ldots \ldots \ldots \ldots \ldots \ldots \ldots \ldots \ldots$

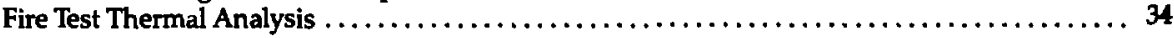

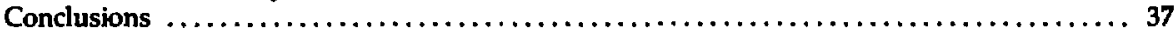

Recommendations for Future Work $\ldots \ldots \ldots \ldots \ldots \ldots \ldots \ldots \ldots \ldots \ldots \ldots \ldots \ldots \ldots \ldots, \ldots \ldots \ldots$

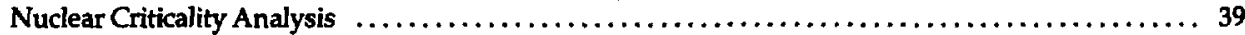

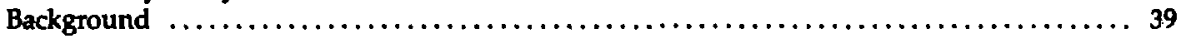

Description of Configurations Analyzed $\ldots \ldots \ldots \ldots \ldots \ldots \ldots \ldots \ldots \ldots \ldots \ldots \ldots \ldots$

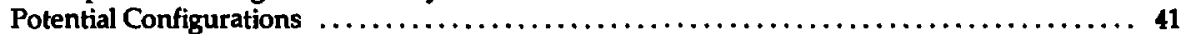

Accounting for Fissile Inventory Depletion $\ldots \ldots \ldots \ldots \ldots \ldots \ldots \ldots \ldots \ldots \ldots \ldots \ldots \ldots \ldots$

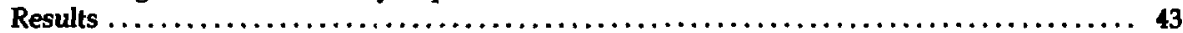

Conclusions $\ldots \ldots \ldots \ldots \ldots \ldots \ldots \ldots \ldots \ldots \ldots \ldots \ldots \ldots \ldots \ldots \ldots \ldots \ldots \ldots \ldots \ldots \ldots \ldots, \ldots \ldots$

Recommendations for Further Analysis $\ldots \ldots \ldots \ldots \ldots \ldots \ldots \ldots \ldots \ldots \ldots \ldots \ldots \ldots \ldots \ldots 44$

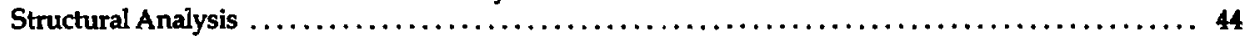

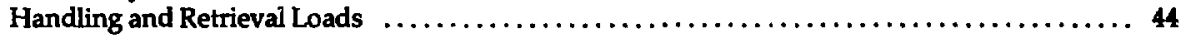

Fire Test Structural Analysis $\ldots \ldots \ldots \ldots \ldots \ldots \ldots \ldots \ldots \ldots \ldots \ldots \ldots \ldots \ldots \ldots \ldots \ldots$ 


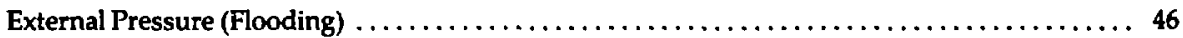

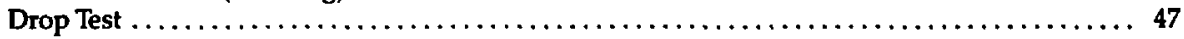

Future Analyses $N \epsilon$ eded $\ldots \ldots \ldots \ldots \ldots \ldots \ldots \ldots \ldots \ldots \ldots \ldots \ldots \ldots \ldots \ldots \ldots \ldots \ldots, 48$

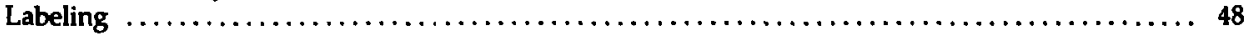

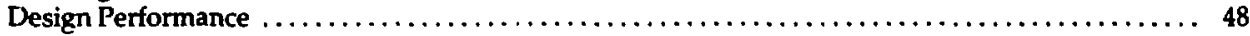

Spent Fuel Canisters $\ldots \ldots \ldots \ldots \ldots \ldots \ldots \ldots \ldots \ldots \ldots \ldots \ldots \ldots \ldots \ldots \ldots \ldots \ldots \ldots \ldots, 48$

West Valley/Defense High Level Waste Packages $\ldots \ldots \ldots \ldots \ldots \ldots \ldots \ldots \ldots \ldots \ldots \ldots \ldots \ldots 2$

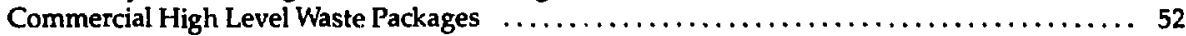

Consideration of Desirable Design Characteristics $\ldots \ldots \ldots \ldots \ldots \ldots \ldots \ldots \ldots \ldots \ldots \ldots \ldots \ldots \ldots \ldots$

Standardization $\ldots \ldots \ldots \ldots \ldots \ldots \ldots \ldots \ldots \ldots \ldots \ldots \ldots \ldots \ldots \ldots \ldots \ldots \ldots \ldots \ldots \ldots \ldots, 53$

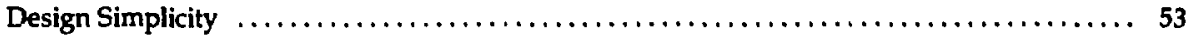

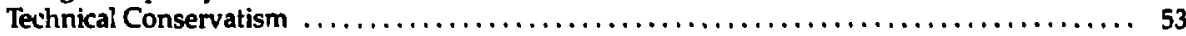

Conventional Materials and Fabrication Techniques $\ldots \ldots \ldots \ldots \ldots \ldots \ldots \ldots \ldots \ldots \ldots \ldots, 53$

Compatibility with Waste Processing, Tr.nnsportation, Consolidation,

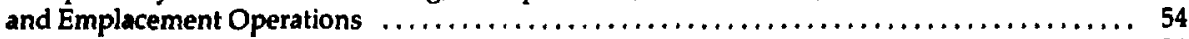

Cost Effectiveness $\ldots \ldots \ldots \ldots \ldots \ldots \ldots \ldots \ldots \ldots \ldots \ldots \ldots \ldots \ldots \ldots \ldots \ldots \ldots \ldots \ldots \ldots \ldots \ldots \ldots \ldots$

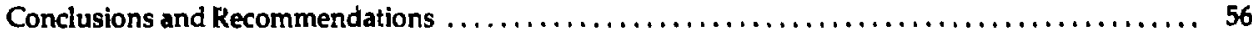

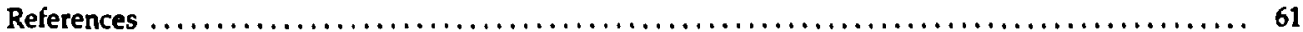




\section{List of Figures}

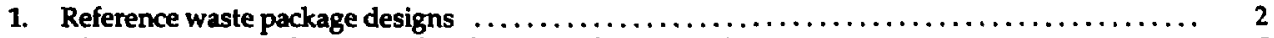

2. Alternative design for consolidated spent fuel waste package $\ldots \ldots \ldots \ldots \ldots \ldots \ldots \ldots \ldots \ldots \ldots, 7$

3. Plan view of the proposed Yucca Mountain repository $\ldots \ldots \ldots \ldots \ldots \ldots \ldots \ldots \ldots \ldots \ldots \ldots \ldots, 11$

4. Repository plan view: vertical emplacement $\ldots \ldots \ldots \ldots \ldots \ldots \ldots \ldots \ldots \ldots \ldots \ldots \ldots \ldots \ldots \ldots$

5. Repository plan view: horizontal emplacement $\ldots \ldots \ldots \ldots \ldots \ldots \ldots \ldots \ldots \ldots \ldots \ldots \ldots \ldots, \ldots \ldots \ldots$

6. Detailed drift elevation view: vertical emplacement $\ldots \ldots \ldots \ldots \ldots \ldots \ldots \ldots \ldots \ldots \ldots \ldots \ldots \ldots . \ldots \ldots$

7. Detailed drift plan view: horizontal emplacement $\ldots \ldots \ldots \ldots \ldots \ldots \ldots \ldots \ldots \ldots \ldots \ldots \ldots \ldots$

8. BWR spent-fuel canister, $7 / 14$ assemblies vertically emplaced $\ldots \ldots \ldots \ldots \ldots \ldots \ldots \ldots \ldots \ldots \ldots 21$

9. PWR spent-fuel canister, $3 / 6$ assemblies horizontally emplaced $\ldots \ldots \ldots \ldots \ldots \ldots \ldots \ldots \ldots . \ldots 22$

10. PWR spent-fuel canister, $2 / 4$ assemblies vertically emplaced $\ldots \ldots \ldots \ldots \ldots \ldots \ldots \ldots \ldots \ldots . \ldots \ldots$

11. PWR spent-fuel canister, 2/4 assemblies with packing

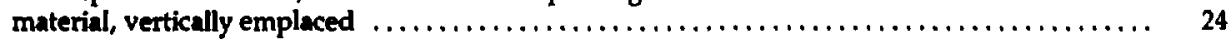

12. Conceptual designs for WV/DHLW and CHLW canisters:

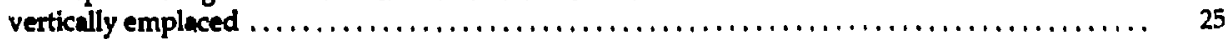

13. Temperature histories of waste package components and host rock for vertically-emplaced spent-fuel canister (case 25$) \ldots \ldots \ldots \ldots \ldots \ldots \ldots \ldots \ldots \ldots$

14. PWR spent fuel canister model: horizontal emplacement (case 22 ) $\ldots \ldots \ldots \ldots \ldots \ldots \ldots \ldots \ldots$

15. Temperature histories of waste package components and host rock for horizontally emplaced pre-consolidated (boxed) PWR spent fuel (case 22) $\ldots \ldots \ldots \ldots \ldots \ldots \ldots \ldots \ldots \ldots \ldots \ldots \ldots \ldots \ldots \ldots \ldots, \ldots \ldots$

16. Temperature histories of waste package components and host rock for horizontally-emplaced WVIDHLW canister (case 2$) \ldots \ldots \ldots \ldots \ldots \ldots \ldots \ldots$

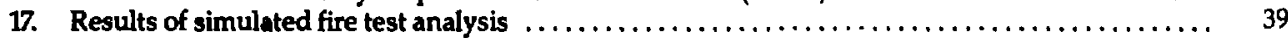

18. Spent fuel container cross section $\ldots \ldots \ldots \ldots \ldots \ldots \ldots \ldots \ldots \ldots \ldots \ldots \ldots \ldots \ldots \ldots \ldots \ldots \ldots, 40$

19. Spent fuel waste package used in analysis $\ldots \ldots \ldots \ldots \ldots \ldots \ldots \ldots \ldots \ldots \ldots \ldots \ldots \ldots \ldots \ldots \ldots, 41$

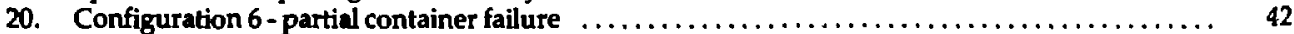

21. Configuration 10 -geometry $\ldots \ldots \ldots \ldots \ldots \ldots \ldots \ldots \ldots \ldots \ldots \ldots \ldots \ldots \ldots \ldots \ldots, 43$

22. Finite element mesh used to calculate waste package stresses during retrieval $\ldots \ldots \ldots \ldots \ldots \ldots \ldots \ldots \ldots \ldots \ldots \ldots \ldots \ldots \ldots \ldots \ldots \ldots \ldots \ldots, 45$

23. Calculated stress contours on waste package resulting from retrieval loads

24. Calculated stress contours on waste package resulting from fire-test-induced internal pressure of $180 \mathrm{psi}$

25. Calculated canister deformations resulting from a simulated drop test 


\section{List of Tables}

1. Waste package design requirements and

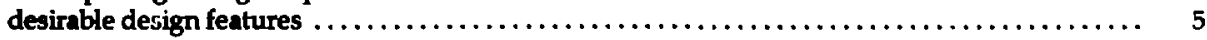

2. High level waste package costs $\ldots \ldots \ldots \ldots \ldots \ldots \ldots \ldots \ldots \ldots \ldots \ldots \ldots \ldots \ldots \ldots \ldots \ldots \ldots, 8$

3. Waste emplacement schedule for the first repository $\ldots \ldots \ldots \ldots \ldots \ldots \ldots \ldots \ldots \ldots \ldots \ldots, \quad 10$

4. Assumed waste package environmental conditions $\ldots \ldots \ldots \ldots \ldots \ldots \ldots \ldots \ldots \ldots \ldots \ldots, 12$

5. Reference and alternative design dimensions $\ldots \ldots \ldots \ldots \ldots \ldots \ldots \ldots \ldots \ldots \ldots, \ldots \ldots \ldots, 20$

6. Candidate metals for overpacks $\ldots \ldots \ldots \ldots \ldots \ldots \ldots \ldots \ldots \ldots \ldots \ldots \ldots \ldots, \ldots \ldots \ldots, \quad 26$

7. Key properties of candidate metals $\ldots \ldots \ldots \ldots \ldots \ldots \ldots \ldots \ldots \ldots \ldots \ldots \ldots \ldots \ldots \ldots \ldots \ldots, 27$

8. Ranking summary for candidate metals $\ldots \ldots \ldots \ldots \ldots \ldots \ldots \ldots \ldots \ldots \ldots \ldots \ldots \ldots \ldots \ldots \ldots \ldots, 29$

9. Equivalent spent fuel material properties used for

10. Tuff material properties used for thermal analyges $\ldots \ldots \ldots \ldots, \ldots, \ldots, \ldots, \ldots \ldots \ldots, \quad 32$

11. Significant input parameters and output results for

12. Criticality analysis: eleven potential configurations $\ldots \ldots \ldots \ldots \ldots \ldots \ldots \ldots \ldots \ldots \ldots, \quad 42$

13. Results of KENO-IV analyses $\ldots \ldots \ldots \ldots \ldots \ldots \ldots \ldots \ldots \ldots \ldots \ldots \ldots \ldots \ldots \ldots \ldots, \quad 44$

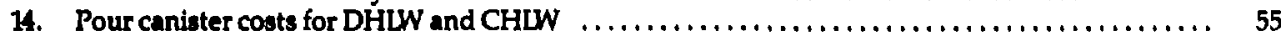

15. Cylinder and end cap costs $\ldots \ldots \ldots \ldots \ldots \ldots \ldots \ldots \ldots \ldots \ldots \ldots \ldots \ldots \ldots \ldots \ldots \ldots \ldots \ldots, \quad 55$

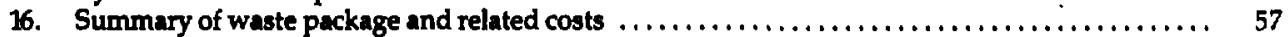

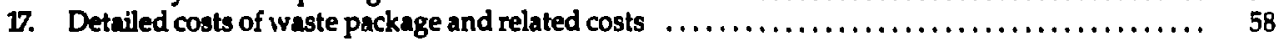




\title{
Preclosure Analysis of Conceptual Waste Package Designs for a Nuclear Waste Repository in Tuff
}

\begin{abstract}
This report discusses the selection and analysis of conceptual waste package designs developed by the Nevada Nuclear Waste Storage Investigations (NNWSI) project for poissible disposal of high level nuclear waste at a candidate site at Yucca Mountain, Nevada. The design requirements that the waste packages must conform to are listed, as are several desirable design considerations. Illustrations of the reference and alternative designs are shown. Four austenitic stainless steels (316L SS, 321 SS, 304L SS and Incoloy 825 high nickel alloy) have been selected for candidite canister/overpack materials, and 1020 carbon steel has been selected as the reference metal for the borehole liners. A summary of the results of technical and economic analyses supporting the selection of the conceptual waste package designs is included. Postclosure containment and release rates are not analyzed in this report.
\end{abstract}

\section{Executive Summary}

Under the direction of the Office of Civilian Radioactive Waste Management, the Department of Energy's (DOE) Nevada Nuclear Waste Storage Investigations (NNWSI) project is evaluating a candidate repository site at Yucca Mountain, Nevada, for permanent disposal of high level nuclear waste. The Lawrence Livermore National Laboratory (LLNL), a participant in the NNWSl project, is developing waste package designs to meet NRC requirements. Included are designs for the reference waste form configurations of: (1) spent fuel (SF), which consists of both consolidated and unconsolidated spent fuel rods from pressurizedwater-reactor (PWR) and boiling-water-reactor (BWR) assemblies, (2) cominercial high level waste (CHLW), as a borosilicate glass containing commercial spent fuel reprocessing wastes, and (3) West Valley/defense high level waste (WVI DHLW) immobilized in borosilicate glass. Reference and alternative package designs have been developed for each waste form for both vertical and horizontal emplacement configurations. All designs are for emplacement in a tuff repository located above the water table (in the vadose zone).

Conceptual designs and analyses for waste packages in tuff below the water table were developed for the Office of Nuclear Waste Isolation
(ONWI) by Westinghouse Electric Corporation in 1981-82 (Westinghouse, 1983). The candidate horizon was changed by NNWSI to the vadose zone in late 1982 (Vieth, 1982; Dudley and Erdal, 1982). LLNL has made changes in and additions to the conceptual designs to reflect this change in the repository location. Analyses have been performed to determine conformance of the selected design ensemble to NRC design requirements in the currently understood repository environment. Figure 1 shows the reference conceptual designs. The selected designs (Gregg and $O^{\prime}$ Neal, 1983) include reference and alternative designs that vary in complexity, performance, and cost.

From this ensemble, one set of designs (for SF, CHIW, and WV/DHLW) will be chosen which is expected to meet Nuclear Regulatory Commission (NRC)/Environmental Protection Agency (EPA) requirements when analyzed with accurate repository data and long term corrosion and release rate data under development (McCright et al., 1983; Oversby, 1983).

The conceptual designs considered to date do not include waste packages for transuranic waste (TRU). These conceptual designs will be developed in the future when more information on the characteristics of TRU waste forms is available. 

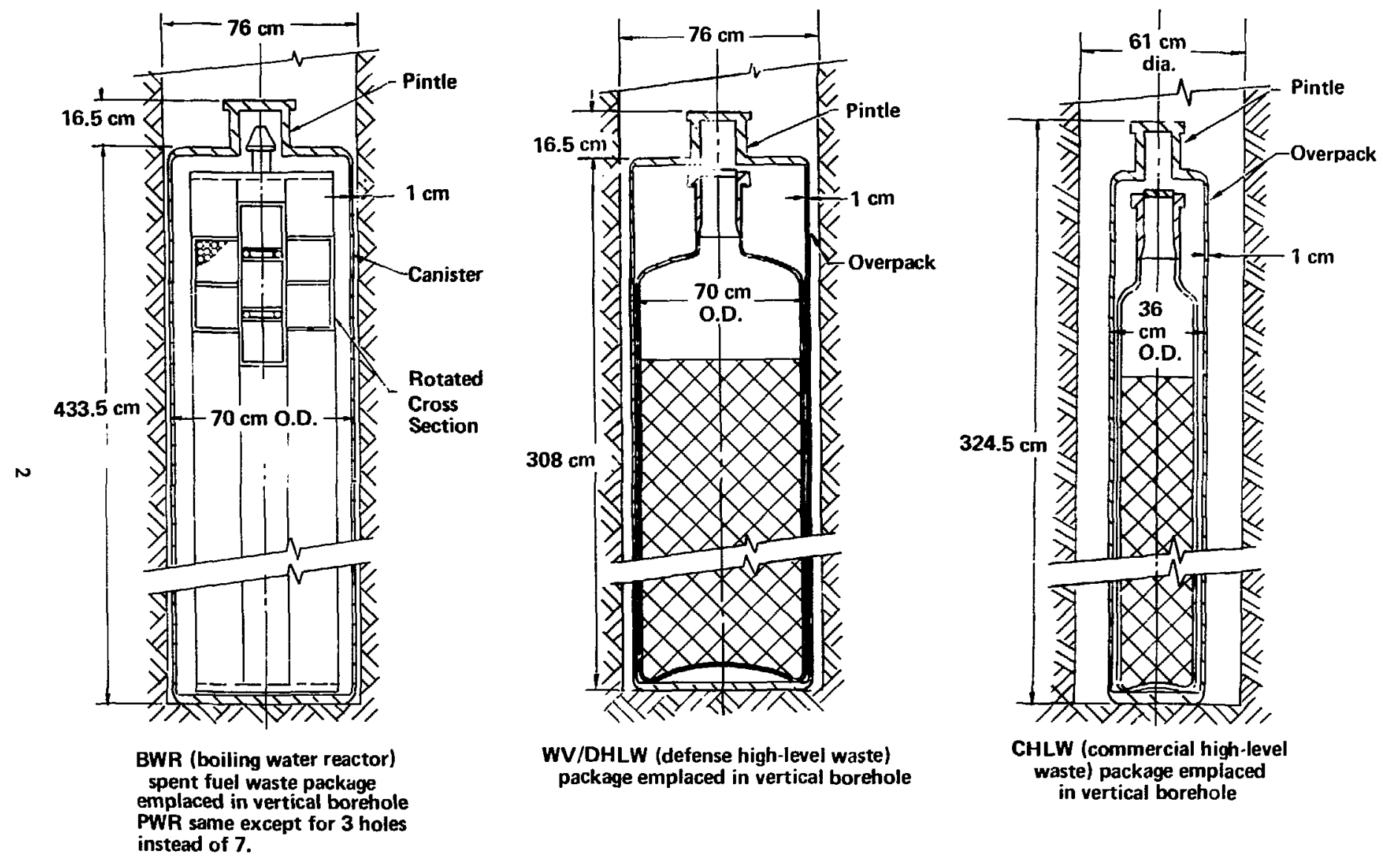

Figure 1. Reference waste package designs. 


\section{Waste Package Environment Assumed for Design and Analysis}

The candidate repository horizon is located in densely welded tuff, 350 to $400 \mathrm{~m}$ below the surface, and approximately $100 \mathrm{~m}$ above the water table. Our current design assumptions on the expected repository environment prior to closure are - as follows: the hydrostatic and lithostatic forces on the waste package will be essentially zero, although there will potentially be some pressure (nominally $0.1 \mathrm{MPa}$ ) on canisters due to sloughing of borehole walls; the air pressure will be 1 atm; and less than $1 \mathrm{~mm}$ per year of water will be dripping on or seeping around the waste packages (Montazer and Wilson, 1984). When heat generated by radioactive decay raises the borehole wall to temperatures above $95^{\circ} \mathrm{C}$, the packages will experience a steam-air mixture. After the borehole walls cool to $95^{\circ} \mathrm{C}$, if the rock has rehydrated, water may drip onto the packages and evaporate for some time (some spent fuel canisters stay above $95^{\circ} \mathrm{C}$ for several hundred years in these designs). Gamma radiation may alter the chemistry of the air and water around the canisters (McCright et al., 1983).

\section{Preclosure Envirorment and Effects on Canisters}

The initial preclosure environment for WVI DHLW and CHLW pour canisters is associated with the canister fabrication and the glass pouring operations. For DHLW, the reference canister design is a pour canister, $1-\mathrm{cm}(0.394$ in)-thick, $51-\mathrm{cm}$ (24-in)-diameter 304L stainless steel (SS) container filled with a molten glass and waste mixture and emplaced within an overpack.

Differential thermal contraction and deforma. tion between the 304L SS wall and hot glass during cooling produces a complicated stress distribution in the canister wall (Baxter, 1983; Slate et al., 1981). The time/temperature history and accumulated residual stress pattern may cause sensitization (carbide precipitation) in the SS and create conditions leading to stress corrosion cracking susceptibility after emplacement (McCright et al., 1983; Slate et al., 1981). The reference CHLW pour canister design is identical to the WV/DHLW canister, except that the diameter, is $32 \mathrm{~cm}$ (12 in). Because of residual stresses and sensitization, WV/DHLW and CHLW pour canisters will be overpacked in the reference design.
The shipping and handling environment of the stressed WVIDHLW and CHLW pour canisters are not expected to change the physical or chemical state of the canisters, provided that the canisters are securely fixed in their shipping casks and federal transportation regulations are followed. At the repository, the normal (non-accident) handling, transporting, and emplacement environment should not overstress the pour canisters. Retrieval operations could produce additional stresses in nonoverpacked pour canisters depending on the integrity of the emplacement hole and liner at retrieval. For pour canisters, stresses imposed during retrieval would be superimposed onto existing thermally indured stresses from glass-pouring operations. These are additional preclosure conditions under which the reference design requires an overpack.

The reference spent fuel canister is fabricated from an austenitic stainless steel such as $304 \mathrm{~L}$, 316L, 321 or Incoloy 825 with a wall thickness of $1 \mathrm{~cm}$. End caps are $3.8 \mathrm{~cm}$ thick. For these spent fuel canisters and for pour canister overpacks, calculations indicate that the normal emplacement and retrieval operations will nct produce stresses above allowable limits. For design purposes, the properties of $304 \mathrm{~L}$ or $316 \mathrm{~L}$ stainless steel were used as typical of austenitic stainless steels.

Fire test and drop test environments for SF canisters and pour canisters would impose high stresses (tests will be conducted on several prototype canisters). Calculations and data on fire test stresses (Ross and Mendel, 1979) and reports on drop tests of SF canisters (Kurasch, 1980; Slate et al., 1981) indicate that reference designs for SF canisters and pour canister overpacks could meet requirements for these tests. Plastic deformations occurring during drop tests of pour canisters will be superimposed onto deformations that take place in pouring operations. Temperatures up to $800^{\circ} \mathrm{C}$ for $30 \mathrm{~min}$ will occur in fire tests. Fire test heating of pour canisters increases internal gas pressure but may actually lower the residual tensile stress in the canister wall as it expands away from the glass.

\section{Design Objective, Philosophy and Description}

The objective of the package design effort is to develop and analyze waste package designs that incorporate qualified materials and are fully compatible with the repository design. The designs 
and analyses are needed to support license application by demonstration conformance with requirements for safe handling, transportation, emplacement, retrieval, containment of radioactive waste, and control of radionuclide release rate per the NRC 10 CFR 60 and 10 CFR 71 regulations.

The basic design philosophy for waste package conceptual designs is to meet NRC design criteria with flexibility in technical performance and cost. This approach allows for the present uncertainties in the repository environment, corrosion rates and radionuclide release rates. To accomplish this, we have selected conservative ${ }^{\star}$ and economical reference designs as well as alternative designs with greater technical conservatism but added complexity and higher cost. All designs are generally suitable with little or no modification for either vertical or horizontal emplacement.

The reference designs specify austenitic SS spent fuel canisters and overpacked pour canisters. Alternative designs specify more corrosionresistant alloys for containment barriers. Designs have been prepared that include overpacks and packing materials. The alternative designs may be more conservative and costly than the reference designs, but may be necessary to meet NRC criteria if long term corrosion and release rate testing demonstrates that rates are significantly higher than indicated by currently available short term data.

\section{Design Requirements and Constraints}

We are designing waste packages to meet a set of NNWSI requirements derived from NRC 10 CFR 60 (NRC, 1983) and NRC 10 CFR 71 (NRC, 1982) as well as several desirable design features. Table 1 lists these requirements (Russell et al., 1983) and design features.

\section{Nuclear Criticality Safety Analysis of Conceptual Designs}

A criticality safety assessment was made for reference DHLW canisters (Baxter, 1983). The results show that the highest calculated criticality coefficient was $k_{\text {eff }}=0.147$. This value is well below

\footnotetext{
"Here, conservative means use of materials having significantly greater corrosion resiztance, strength and ductility than the least costly available, and design configurations which meet requirements with some safety mangin on temperature limits, criticality, and stress for non-accident conditions.
}

the maximum allowable of 0.95 . The calculations had not included flooding conditions, which may increase $\mathbf{k}_{\mathrm{efr}}$ slightly. However, for DHLW and CHLW, the fissile material content of the waste forms proposed to date is sufficiently low that a criticality accident is not of concern during the containment period (Westinghouse, 1983, p 60). Criticality analysis has not been conducted for long term conditions for glass waste forms.

For various dry and flooded configurations of spent fuel canisters emplaced in the tuff repository, recent criticality calculations show that $k_{\text {vif }}$ is always below 0.95 for spent fuel depleted to $<1.4$ wt\% (weight percent) U-235 (Weren et al., 1983). The calculations indicate that $k_{\text {efl }}$ will be less than 0.95 unless, as required in NRC 10 CFR 60, two unlikely, independent, and concurrent changes have occurred in the conditions essential to nuclear criticality safety. The changes necessary for $k_{\text {eff }}$ to exceed 0.95 are as follows:

1. The emplaced canister is loaded with spent fuel with equivalent (depleted) loading greater than 1.4 to $1.6-w t \%$ U-235. (Undepleted fuel rods will be specially handled in the reposito : Fuel assemblies are normally depleted to 1.0-1.5-wt\% U-235). And,

2. The canister is breached and filled with water. And,

3. The spent fuel rods or space frame have disintegrated. And,

4. a. The spent rods have rearranged into an optimal configuration (>1.6-wt\% U-235). Or,

b. The Zircaloy cladding has disintegrated and all the spent fuel has fallen into a pile (>1.4-wt\% U-235).

Changes in $4 \mathrm{a}$ and $4 \mathrm{~b}$ can be further mitigated by filling empty canister spaces with crushed tuff and/or placing ncutrol absorbing materials in the canister. The reference design specifies neutronabsorbing poison rods, and does not include filler materials for void spaces. Leaving void spaces open increases heat transfer, resulting in lower package temperatures.

\section{Thermal Analysis}

Calculated waste package temperatures for all of the reference and alternative designs are within the temperature limits imposed to avoid wasteform degradation (Stein et al., 1984). These limits are $350^{\circ} \mathrm{C}$ for spent fuel (cladding), $400^{\circ} \mathrm{C}$ for $\mathrm{CHLW}$, and $500^{\circ} \mathrm{C}$ for WV/DHLW. In the canister 
A. Waste package design requirements derived from NRC 10 CFR 60 and 10 CFR 7

Waste packages shall be designed to do the following:

3. Contain the waste for 300 to 1000 years.

2. Maintain a release rate less than $10^{-5}$ per year of the radionuclide inventory present at 1000 years.

3. Maintain retrievability for 50 years after emplacement of the first waste package.

4. Control criticality so as not to exceed an effective multiplication factor $\left(k_{\text {effi }}\right)$ of 0.95 unless more than two unlikely changes occur.

5. Maintain temperatures below limits of the waste forms, which are $773 \mathrm{~K}\left(500^{\circ} \mathrm{C}\right)$ for WVIDHLW glass, $673 \mathrm{~K}$ (400 $\left.{ }^{\circ} \mathrm{C}\right)$ for $\mathrm{CHLW}$ glass, and $623 \mathrm{~K}\left(350^{\circ} \mathrm{C}\right)$ for spent fuel cladding.

6. Prevent release of radioactive material in excess of applicable federal and state standards after a drop test of two times the waste package length onto an unyielding surface, at the minimum anticipated temperature.

7. Prevent release of radioactive material in excess of applicable federal and state standards after sustaining a $1073 \mathrm{~K}$ ( $800^{\circ} \mathrm{C}$ ), 30-minute fire test.

8. Prevent release of radioactive material in excess of applicable federal and state standards under expected loads during or after transportation, handling, emplacement, retrleval, and seismic events. Further, these loads must not compromise longterm performance.

9. Retain legible, externally labeled identification as long as retrievability is required.

10. Meet federal regulatory requirements for transportation of high level nuclear waste.

11. Meet requirements with consideration for cost-effectiveness, including direct package costs and related repository system costs through the operational period.

B. Desirable waste package design features

Waste package designs will do the following:

1. Use standardized components whenever possible.

2. Emphasize simplicity and ease of fabrication.

3. Be technically conservative.

4. Use conventional materials and fabrication techniques.

5. Be compatible with all waste processing, transportation and emplacement operations.

design for consolidated spent fuel, the same diameter canister $(70 \mathrm{~cm})$ will accommodate 14 BWR assemblies ( $3.00 \mathrm{~kW})$ and six PWR assemblies (3.4 kW). For the alternative SF canister with packing, it was necessary to reduce the number of assemblies to four PWR or 11 BWR (2.2 kW) to avoid exceeding the $350^{\circ} \mathrm{C}$ limit.

Results of thermal analyses show that the reference package designs for CHLW and WV/DHLW when emplaced in the reference repository geometry (vertical emplacement) are well below waste form temperature limits. In fact, both CHLW and WVIDHLW canisters could be emplaced at higher areal power density without exceeding temperature limits. The analysis also shows that, depending on detailed configurations and fuel loadings, the reference-design spent fuel canisters can be emplaced in the reference repository and not exceed waste form temperature limits.

\section{Structural Analyses of Canister Designs}

The preclosure environmental history of canisters and overpacks begins with canister fabrica- tion and continues through glass pouring (WV/ DHLW and CHLW only), transportation, handling, welding, emplacement, and possible retrieval. For prototype canisters, fire and drop tests must be completed without canister leakage. Structural analysis is underway to simulate the normal, test, and unexpected environmental conditions that will be imposed on canisters. Drop tests (Ross and Mendel, 1979; Slate et al., 1981; Kurasch, 1980) and overheat tests (Ross and Mendel, 1979) have been conducted on these types of canisters by several organizations. Based on these results, NNWSI canister designs are expected to survive such tests.

Computer simulations of fire tests were performed for a spent fuel canister using TACO2D (Burns, 1982) to calculate internal temperatures from an $800^{\circ} \mathrm{C}, 30-\mathrm{min}$ boundary condition. These temperatures were used to calculate internal pressures. The internal pressure was applied on a boundary condition to model canister stresses using NIKE2D (Hallquist, 1979). Assuming increased pressure from fuel-rod gas release, the maximum stress in a 70-cm-diameter canister is 
15,000 psi. This gives a safety factor of 1.36 on ultimate strength.

Structural analysis for normal lifting loads (for the $70-\mathrm{cm}$-diameter canister) using NIKE2D gave a maximum stress of $4,780 \mathrm{psi}$ (in the pintle). A retrieval load of $79,000 \mathrm{lb}$ can be applied on the pintle without exceeding the $316 \mathrm{~L}$ stainless steel yield strength of $30,000 \mathrm{psi}$ in the pintle or canister. The retrieval load to maintain a safety margin of three on yield is $26,333 \mathrm{lb}$.

To estimate the effect of an (unexpected) flooding of the repository, a computer-simulated hydrostatic pressure was applied to the outside of the canister. The yield strength was not exceeded until 400 psig of water pressure was applied (70$\mathrm{cm}$-diameter canister). This pressure would result from a water head of over $922 \mathrm{ft}(281 \mathrm{~m})$. Essentially no reduction in wall thickness or strength is expected during the pre-closure period. Canister strength is therefore sufficient to allow for unlikely flooding incidents, and for significant loadings from local rock failures.

Structural analysis of advanced conceptual canister designs and other environmental conditions is continuing. The results thus far indicate that all concepts can be detail designed to meet strength requirements over the expected range of preclosure environments.

\section{Design Description}

\section{Reference Designs}

The reference conceptual designs are shown in Figure 1. The reference spent fuel canister is 70 $\mathrm{cm}$-diameter with 4.00-, 4.50-, and 4.75-m lengths (plus pintle) to accommodate spent fuel rods of various lengths. The canisters are fabricated from an austenitic stainless steel with wall thicknesses of $1 \mathrm{~cm}$ (the properties of 316L stainless are used for purposes of design and analysis). The pintles $(16.5 \mathrm{~cm})$ are similar to pour canister pintles.

The internal space-frame for spent fuel canisters provides mechanical stability and enhances heat transfer. For consolidated rods, preconsolidated or intact assemblies, the space-frame consists of a 1-cm-thick pigeon-hole array of 304 SS with square receptacles with end plates and pintle. The PWR canister contains three intact or six preconsolidated PWR assemblies. For BWR assemblies, it contains up to seven intact or 14 preconsolidated assemblies. The $70-\mathrm{cm}$ diameter for preconsolidated boxed assemblies is contingent upon the successful two-for-one volume reduction envisaged and demonstrated for preconsolidation (Ander- son, 1982). The reference WV/DHLW and CHLW designs use an overpack $330 \mathrm{~cm}$ long. The $32-\mathrm{cm}-$ diameter CHLW pour canister and the $61-\mathrm{cm}-$ diameter WV/DHLW pour canister are both nominally one $\mathrm{cm}$ thick, 304L stainless steel with identical pintles of the Savannah River type (Baxter, 1983). Single package emplacement in vertical boreholes is the reference emplacement configuration.

\section{Alternative Designs}

Several alternative design configurations have been considered, including self-shielded packages, titanium-carbon steel composites, and multiple glass waste form canisters in a single overpack. These concepts have been eliminated from further consideration.

An alternative design that includes a precompressed tuff packing material outside the containment barrier continues to be a possible configuration for spent fuel packages. The need for packing material will be determined from results of spent fuel release-rate testing.

The alternative emplacement mode is horizontal emplacement. A carbon steel liner will be used to facilitate emplacement and retrieval. Reference and alternative package designs can be emplaced horizontally. Figure 2 shows the alternative spent fuel package design with packing emplaced vertically.

\section{Cost Effectiveness}

Costs have been estimated for all reference and alternative designs. The most cost effective designs are those that maximize the canister size without exceeding waste-form temperature limits. Table 2 shows costs of reference and alternate vertically emplaced waste-package and related repository-systems costs for a 70,000 metric tons of uranium (MTU) all-spent-fuel repository. Columns $F$ and $G$ show the cost of 300 West Valley high level waste (WVHLW) waste packages with and without overpacks (costs of pour canisters are not included because they will be borne by the waste processor). Column $\mathrm{H}$ shows costs of $\mathbf{5 0 0 0}$ cans of spent fuel hardware from consolidation operations. Columns I and J show the cost of 26,000 canisters of consolidated spent fuel and columns $\mathrm{K}$ and $\mathrm{L}$ are for 52,000 canisters of intact spent fuel. Repository costs included are shown in Table 2 (Scully et al., 1983a). Repository costs not included are the following: most surface facilities 


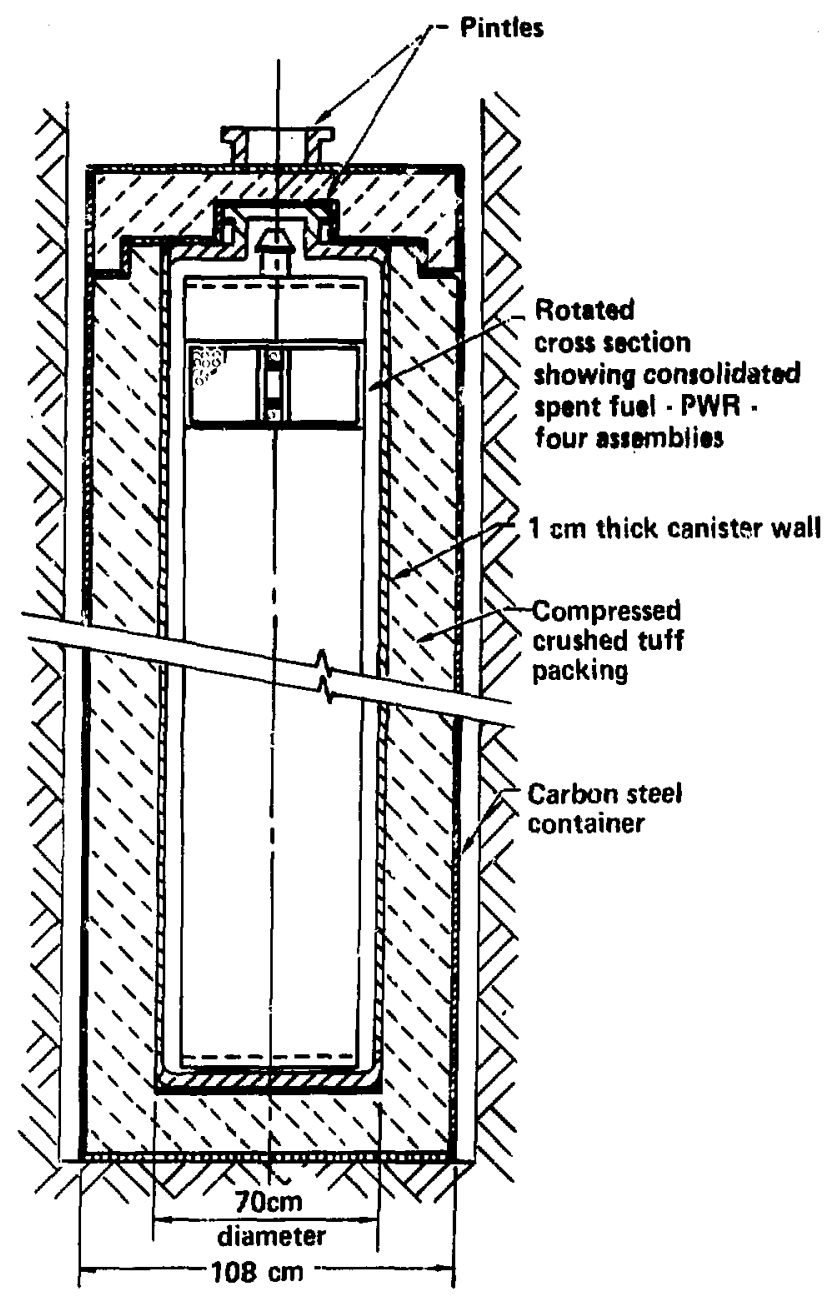

Figure 2. Alternative design for consolidated spent fuel waste packages if packing (backfill) is needed to reduce release rate.

and some subsurface facilities (not including ventilation shafts, entrance, service areas, sealing, backfill, retrieval). The only surface-facility cost inclured is an approximate cost for spent fuel consolidation hot cells at $\$ 100$ million (Stearns-Roger, 1983).

Line 137 shows that the total cost of consolidated spent fuel is $\$ 1827 \mathrm{M}$ including 5000 cans of SF hardware, which is significantly less than for intact assemblies at $\$ 2549 \mathrm{M}$. The cost of consolidation labor and facilities would have to increase from the estimated $\$ 3000 /$ can to about $\$ 28,000 /$ can to make it uneconomical to consolidate spent fuel.

\section{Conclusions}

The reference and alternative conceptual designs provicie a group of design concepts suitable for development of preliminary and final dusign of waste packages. Within the variations in materials and configurations available, final designs are expected to meet all regulatory iequirements. 
Table 2. Summary of wate package (WP) and related costs for vertical emplacement.

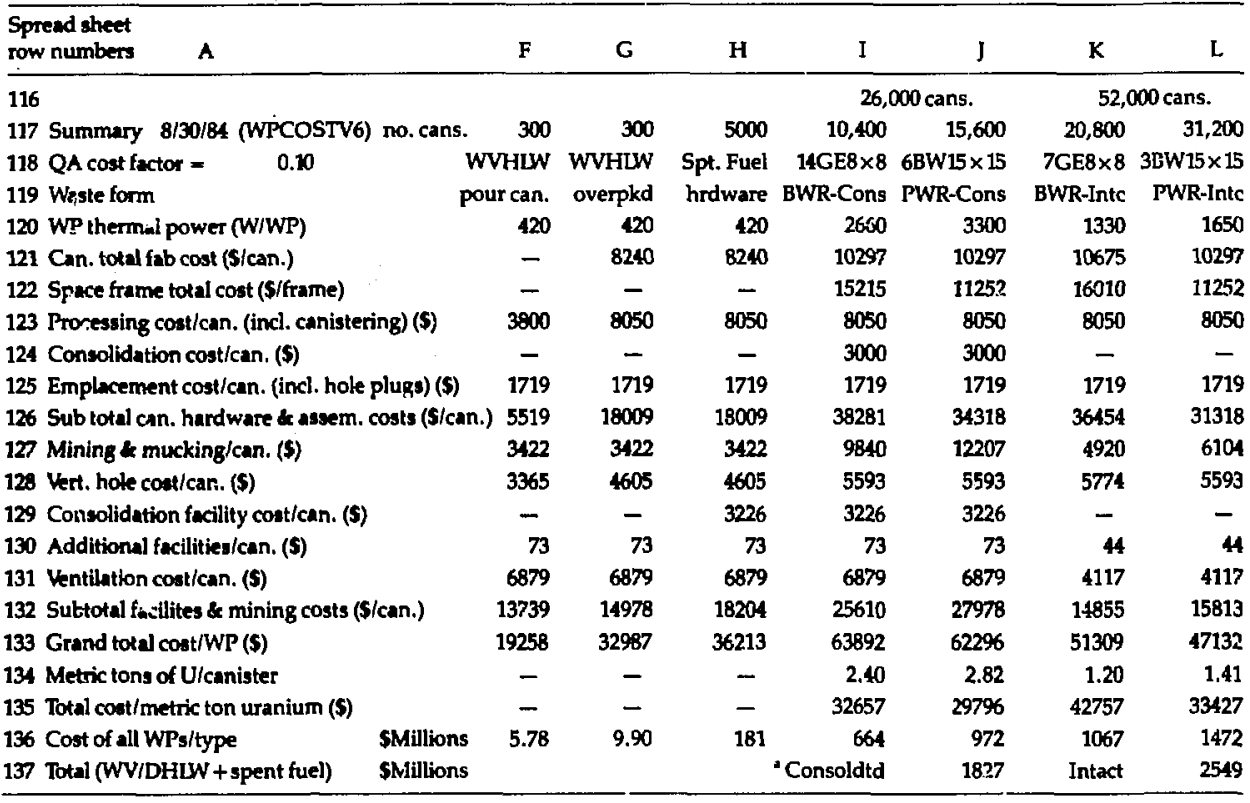

138 - Spent fuel hardware included in total consolidated cost.

\section{Section I \\ Conceptual Waste Package Designs}

\section{Introduction}

\section{Background}

During 1981-82, Westinghouse Advanced Energy Systems Division, Pittsburgh, PA, developed conceptual waste package designs for a tuff repository below the water table. In 1982, the candidate repository horizon was changed to a stratum above the water table in the unsaturated zone. Westinghouse considered this in their final report. In 1982-83, LLNL further developed and analyzed these concepts for the unsaturated zone, and selected a set of conceptual designs in September 1983. During 1983 and the first-half of 1984, LINNL performed detailed analyses of these designs. Some design modifications were made as a result of these design analyses, as well as from evolutionary changes in NNWSI and headquarters in- put (Systems Description), and in response to the Nuclear Waste Policy Act of 1982, and the final form of NRC 10 CFR 60.

The reference and alternative designs shown in this report have evolved during the analytical process, and therefore the reported analyses do not exactly match the current designs. However, conclusions are drawn as to the likelihood that similar detailed prototype and final designs will meet the requirements based on the analyses completed thus far. Complete analysis of prototype, preliminary and final designs will be reported in the future.

In May 1984 copper and copper-based alloys were added to the materials to be evaluated for containment barriers. Designs and analyses for copper and copper-alloy canisters have not been developed and are not included in this report. 
In June 1984 it was decided to adopt the generic austenitic stainless steel alloys as the reference material for NNWSI containment barriers. This decision reflects the requirement for additional corrosion testing of several alloys in this group before there is a sound technical basis for a specific alloy selection. This selection is scheduled to be made in 1987 and will be based on comprehensive testing in both anticipated and unanticipated, but credible simulated repository environments.

This report does not include waste package performance analysis for postclosure periods because, at this time, available data and existing models are inadequate for such an analysis. The purpose of this report is to present the latest selected conceptual design configurations and the analysis done on these evolving concepts during 1983-84. The next phase in the NNWSl package design subtask is advanced conceptual design and analysis and detailed design and analysis of prototype canisters.

\section{Waste Forms and Quantities}

The conceptual waste package designs presented in this report are for three waste forms: spent fuel, commercial high level waste, and West Valley/defense high level waste (see Oversby, 1984 for waste form characteristics). A summary of their anticipated quantities is in Table 3 ( $O^{\prime} B$ rien, 1984). Transuranic (TRU) waste forms are not considered in this report.

Spent Fuel (SF). The reference form of spent fuel consists of spent fuel rods that have been removed from the intact assemblies and consolidated into square-hole arrays in canisters that vary in length, depending on the dimensions of the fuel rods. The reference canister for pressurized-water-reactor and boiling-water-reactor fuel rods is $70 \mathrm{~cm}$ in diameter and $450 \mathrm{~cm}$ long (plus pintle). The PWR and BWR canisters will have maximum thermal power of approximately $3450 \mathrm{~W}$ per canister. Power per canister will vary depending on age, burn-up, and whether intact or consolidated assemblies are stored within.

Commercial High Level Waste (CHLW). The reference CHLW form is borosilicate glass which is poured, while molten, into stainless steel canisters $32 \mathrm{~cm}$ in diameter and $300 \mathrm{~cm}$ long. As with West Valley waste and defense high level waste, these canisters are filled to about $85 \%$ capacity to preclude overfilling (Slate et al., 1981).

The source of this waste form will be spent fuel reprocessing plants. If such plants are put into operation, the repository will have to be prepared to handle a total of 15,350 such packages at a rate of 660 packages per year. The thermal power will be approximately $2210 \mathrm{~W}$ per package (Westinghouse, 1983). CHLW is not considered in detail, but can be accommodated in overpacks.

West Valley/Defense High Level Waste (WVI DHLW). The reference form of WVIDHLW is borosilicate glass which is poured, while molten, into a $304 \mathrm{~L}$ stainless steel canister $61 \mathrm{~cm}$ in diameter and $300 \mathrm{~cm}$ long. The canister is filled to only $85 \%$ capa ity to preclude overfilling (Baxter, 1983).

The primary source of this waste will be the West Valley Plant and possibly the Savannah River Plant, which is expected to produre a total of 6720 packages at a rate of 500 packages per year. These packages are expected to have a maximum thermal output of $423 \mathrm{~W}$ per paclsage, assuming 10year-old waste. The West Valley Plant is expected to produce an additional 310 packages which are expected to be disposed of over a period of a single year. These packages are expected to have a thermal output of less than $300 \mathrm{~W}$ per package (Westinghouse, 1983), and will be overpacked in austenitic stairiless steel overpacks.

\section{Repository Location and Waste Package Environment}

The NNWSI Project has selected the Topopah Spring member of the Paintbrush Tuff as the candidate horizon for a repository sited at Yucca Mountain. A typical plan view of the repository is presented in Figure 3 (Scully et al., 1983b). The repository will be located in a welded portion of the tuff unit at an elevation of about $2900 \mathrm{ft}(884 \mathrm{~m})$ and will lie approximately 350 to $400 \mathrm{~m}$ below surface level. The static water level is more than 100 meters below the repository level. The depths given here are based on information obtained from geologic and hydrologic boreholes placed around the edge of the repository block and from the principal borehole (USW G-4) at the Exploratory Shaft location. The exact depth of the repository horizon will be established during the sitecharacterization phase of the program.

The choice of the unsaturated zone marks a departure from the conventional environment in which repository siting has been proposed. There are many characteristics of the unsaturated zone that make use of this regime particularly attractive for a high-level-waste (HLW) repository site. Table 4 lists environmental conditions that consitute the waste package design basis. 
Thble 3. Waste emplacement schedule for the first repository.

\begin{tabular}{|c|c|c|c|c|c|c|c|}
\hline \multirow[b]{2}{*}{ Year } & \multicolumn{2}{|c|}{ PWR containers } & \multicolumn{2}{|c|}{ BWR containers } & \multirow{2}{*}{$\begin{array}{c}\text { Total } \\
\text { containers }\end{array}$} & \multirow{2}{*}{$\begin{array}{l}\text { Total } \\
(\mathrm{kW})\end{array}$} & \multirow{2}{*}{$\begin{array}{l}\text { WVHLW } \\
\text { containers }\end{array}$} \\
\hline & Intact & Consolidated & Intact & Consolidated & & & \\
\hline 1998 & 92 & 31 & 96 & 32 & 251 & 284 & 0 \\
\hline 1999 & 81 & 23 & 120 & 34 & 258 & 288 & 0 \\
\hline 2000 & 109 & 26 & 104 & 24 & 263 & 296 & 0 \\
\hline 2001 & 287 & 56 & 219 & 43 & 605 & 675 & $\mathbf{0}$ \\
\hline 2002 & 622 & 98 & 447 & 71 & 1238 & 1375 & 0 \\
\hline 2003 & 0 & 610 & 0 & 436 & 1046 & 2075 & 155 \\
\hline 2004 & $\mathbf{0}$ & 642 & 0 & 401 & 1043 & 2141 & 155 \\
\hline 2005 & 27 & 727 & 0 & 430 & 1184 & 2536 & 0 \\
\hline 2006 & 89 & 662 & 0 & 464 & 1215 & 2658 & $\mathbf{0}$ \\
\hline 2007 & 136 & 626 & 0 & 478 & 1240 & 2801 & 0 \\
\hline 2008 & 131 & 647 & 0 & 458 & 1236 & 2867 & 0 \\
\hline 2009 & 127 & 652 & 0 & 455 & 1234 & 2931 & 0 \\
\hline 2010 & $12 B$ & 638 & 0 & 469 & 1235 & 3009 & 0 \\
\hline 2011 & 137 & 615 & 0 & 457 & 1239 & 3129 & 0 \\
\hline 2012 & 130 & 650 & 0 & 456 & 1236 & 3245 & 0 \\
\hline 2013 & 138 & 628 & 0 & 474 & 1240 & 3338 & 0 \\
\hline 2014 & 137 & 654 & 0 & 448 & 1239 & 3461 & 0 \\
\hline 2015 & 121 & 643 & 0 & 468 & 1232 & 3547 & 0 \\
\hline 2016 & 116 & 642 & 0 & 472 & 1230 & 3652 & 0 \\
\hline 2017 & 115 & 772 & 0 & 470 & 1357 & 3779 & 0 \\
\hline 2018 & 93 & 799 & 0 & 458 & 1350 & 3877 & 0 \\
\hline 2019 & 84 & 793 & 0 & 468 & 1345 & 4019 & 0 \\
\hline 2020 & 92 & 712 & 0 & 534 & 1338 & 4083 & 0 \\
\hline 2021 & 60 & 710 & 0 & 553 & 1323 & 4212 & 0 \\
\hline 2022 & 75 & 719 & 0 & 511 & 1335 & 1289 & 0 \\
\hline 2023 & 63 & 935 & 0 & 518 & 1516 & 4361 & 0 \\
\hline 2024 & 86 & 1024 & 0 & 445 & 1555 & 1557 & 0 \\
\hline 2025 & 3 & 31 & 0 & 17 & 51 & 151 & 0 \\
\hline Total & 3279 & 15825 & 986 & 10544 & 30634 & 77636 & 310 \\
\hline
\end{tabular}

\section{Waste Package Emplacement Configurations}

Two waste emplacement configurations are being considered. These configurations are vertical and horizontal. The reference configuration, vertical emplacement, consists of emplacing the waste canisters in vertical holes bored in the floors of mined drifts. There will be one waste package per borehole. In this report, the reference waste package designs are configurations that are expected to meet NRC criteria in the presently un- derstood repository environment. The alternative designs are considered to be designs that will be resorted to if, as new information is developed, it is found that the reference designs will not meet the performance requirements because of higher than expected corrosion and release rates. The horizontal waste emplacement configuration consists of emplacing the waste canisters in long horizontal holes drilled in the walls of mined drifts. In this case, there will be multiple waste canisters (approximately 40) placed in each borehole. Plan 


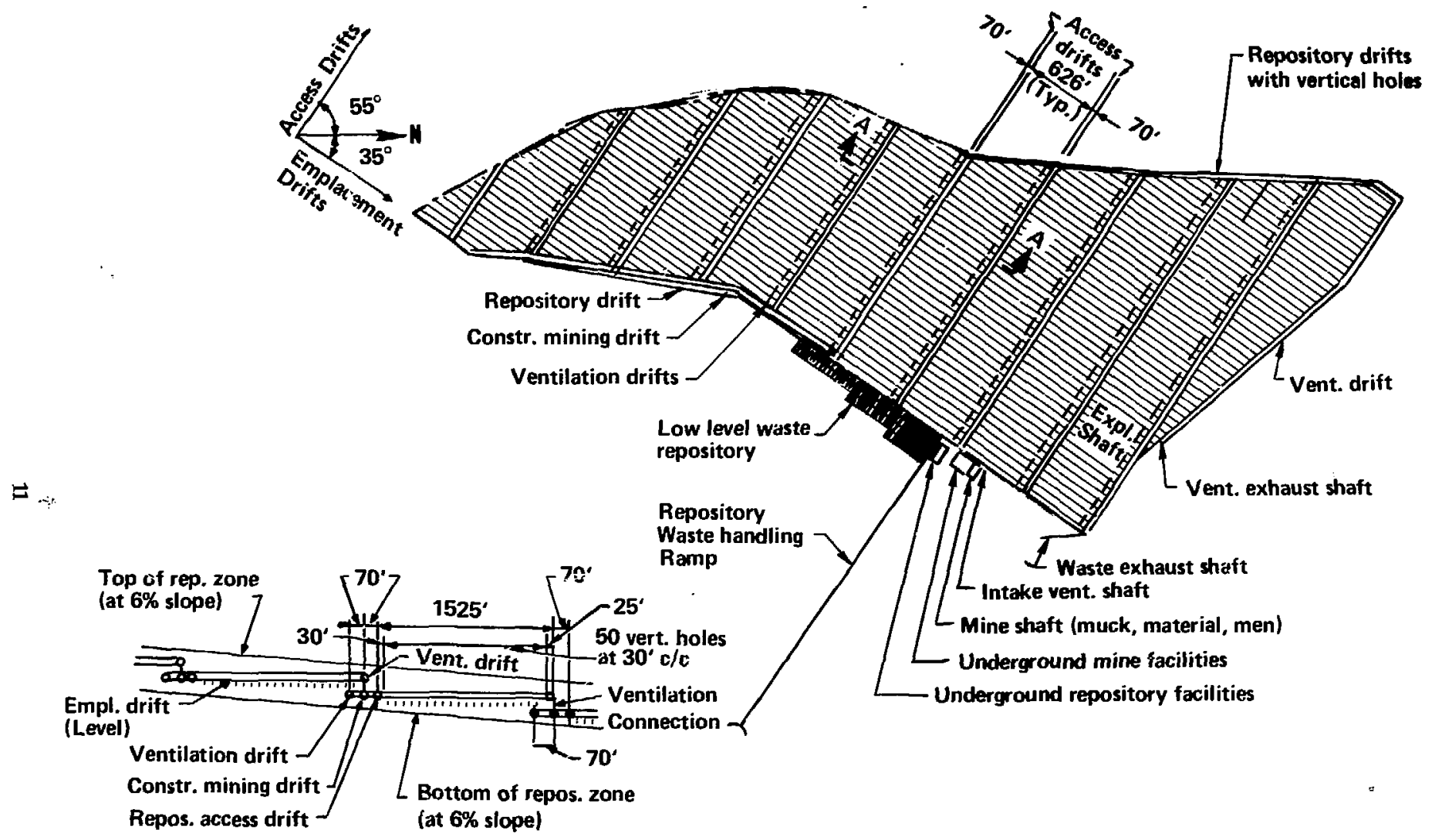

SECTION A-A

Figure 3. Plan view of the proposed Yucca Mountain repository (not to scale). 
Table 4. Assumed waste package environmental conditions (Oversby, 1983).

1. The waste canisters will not be submerged in a continuum of water. Rather, they will be subjected to constant contact with water vapor and to intermittent contact with limited amounts of liquid water.

2. The pressure exerted on the canisters by the environment will be approximately $1 \mathrm{~atm}$. There is no hydrostatic pressure because there is no continuum of water above or around the canisters. A small amount of pressure might be applied to the canisters if localized rock sloughing occurs in emplacement boreholes.

3. The gases to which the canister is exposed will be air plus water vapor if the temperature is more than $95^{\circ}$. This is a consequence of the absence of hydrostatic pressure and elevation ( $884 \mathrm{~m}$ above sea level).

4. Aqueous corrosion of the canister/overpack will begin after the temperature has dropped to less than $95^{\circ}$. This is because liquid water cannot exist in the unsaturated zone at temperatures higher than $95^{\circ}$, the 1-atm boiling point of water at the Topopah Spring elevation.

5. The vadose water and atmosphere of the repository will be mildly oxidizing. Possible increases in salt concentration may result from evaporation of ground water that drips on canisters.

6. Water available for corrosion and waste-form dissolution is limited to the small amount supplied by downwart infiltration from the overlying unsaturated media, a seepage rate currently est imated to be $<1 \mathrm{~mm}$ per year (Mon. tazer and Wilson, 1984).

7. Other environmental conditions might arise during transportation, handling and emplacement operations; during retrieval operations, from sloughing of rock in the emplacement boreholes due to gravity or earthquake loads and vibrations, or as a result of thermal or residual stresses.

8. Conditions (pre-emplacement) resulting from free fall from up to $30 \mathrm{ft}$ on an unyielding surface and from fire imposing an $800^{\circ} \mathrm{C}, 30$-min boundary condition ( $\mathrm{O}^{\prime} \mathrm{Neal}$ et al., 1984).

views of the repository for each emplacement concept are shown in Figures 4 and 5. Detailed elevations of typical emplacement drifts and holes are presented in Figures 6 and 7 (Scully, 1983).

The primary difference between these two configurations is that the horizontal emplacement configuration will require special horizontal boring technology, but will involve the removal (mining and boring) of less rock. This wiil result in a lower degree of disruption of the natural repository geology and less cost, but introduces a higher level of uncertainty as to whether the holes are technically feasible to bore. The equipment and methods required to bore the vertical holes are standard. The boring equipment required to drill the relatively long horizontal emplacement holes is not presently available in the relatively small diameters that are required for waste emplacement. It is anticipated that existing tunnel-boring technology can be adapted to this purpcse, but more equipment development will be required than for the vertical holes (Dravo, 1984).

\section{Waste Package Conceptual Design Selection Philosophy}

Given in this report are approximate dimensions of conceptual waste package designs for High Level Waste (HLW) and four candidate materials that are being considered for the primary (300-to-1000-year) corrosion resistant barrier. The package designs are for vertical and horizontal emplacement configurations. The horizontal boreholes have a carbon steel liner that is assumed to be required for reliable emplacement and retrieval operations. Vertical emplacement is the reference emplacement configuration for all the package designs, and may require a partial borehole liner.

The waste package designs accommodate three basic types of high level waste: SF, WVI DHLW, and CHLW. Both WVIDHLW and CHLW are in the fol $m$ of glass that has been poured into a stainless steel pour canister. The reference designs call for the insertion of the pour canisters into 


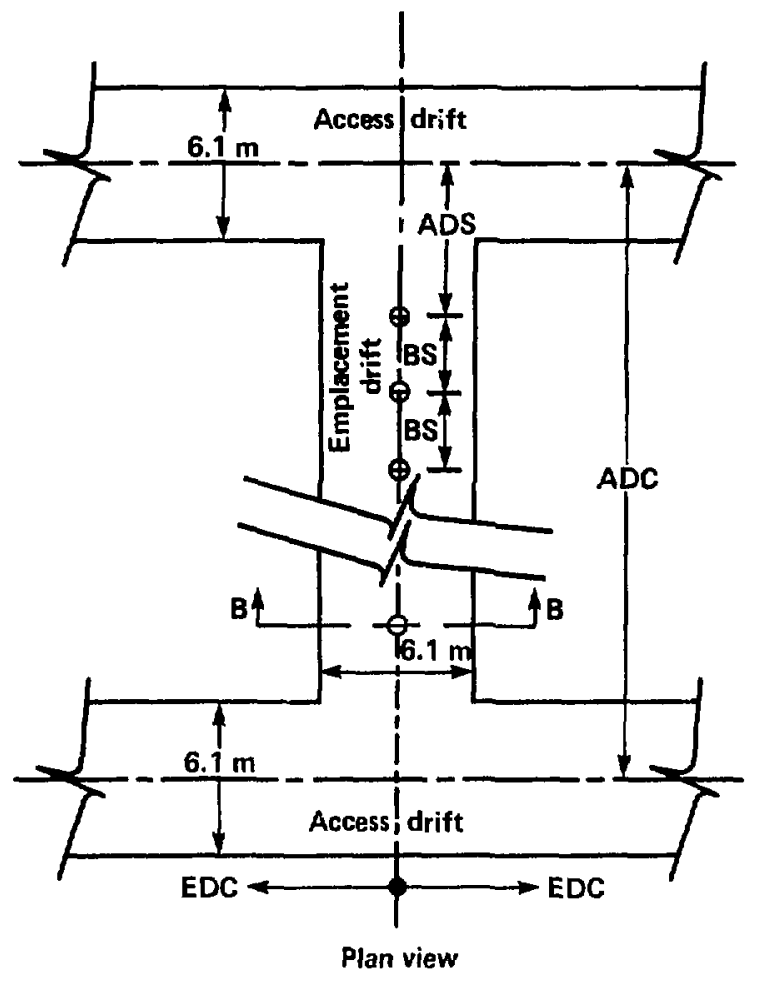

Figure 4. Repository plan view: vertical emplacement where $A D C=$ access drift spacing, EDC $=\mathrm{em}-$ placement drift spacing, BS = borehole spacing, and ADS = access drift standoff,

overpacks that are designed to be the primary containment barrier which will meet the 300-to-1000year containment design requirement. $A$ design for reprocessed waste involving pour canisters emplaced directly into verticai boreholes with no further corrosion-resistant barriers was considered. In this cese, the stainless sted pour canister would serve as the 300-to-1000-year contaimment barrier. This design was considered based on sinplicity, but we do not have sufficient information about the pour canisters to determine if they will be acceptable containment barriers by themselves. The particular concerns are that the thermal cycles associated with the glass-pouring operation will result in the canisters being highly stressed (Baxter, 1983) and sensitized (McCright et al., 1983). These conditions could alter the canistercorrosion mechanism and result in a container that would not be a satisfactory long-tern containment barrier.

Because of the different PWR and BWR designs, there are a variety of PWR and $B W R$ fuel rod and assembly dimensions (Westinghouse, 1983). The reference package design consists of rods consolidated into 304 stainless steel space frames and placed into a $70-\mathrm{cm}$-diameter austenitic stainless steel canister that serves as the 300-to-1000-year containment barrier. The ability to dispose of the intact (nonconsolidated) or preconsolidated boxed fuel rods, as they are received, is retained because it is possible that the operation of consolidating the fuel rods at the repository may be found to be uneconomical or impossible for the fraction of the fuel rod assemblies that nay be damaged. Therefore, canister designs have been developed for disposal of consolidated and preconsolidated 


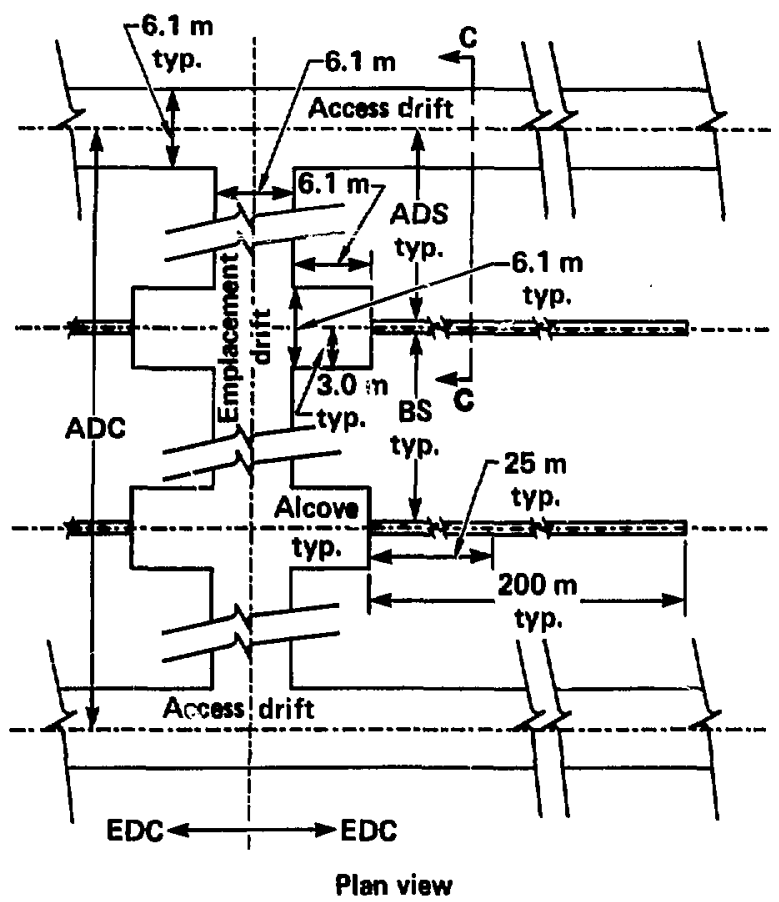

Figure 5. Repository plan view: horizontal emplacement.

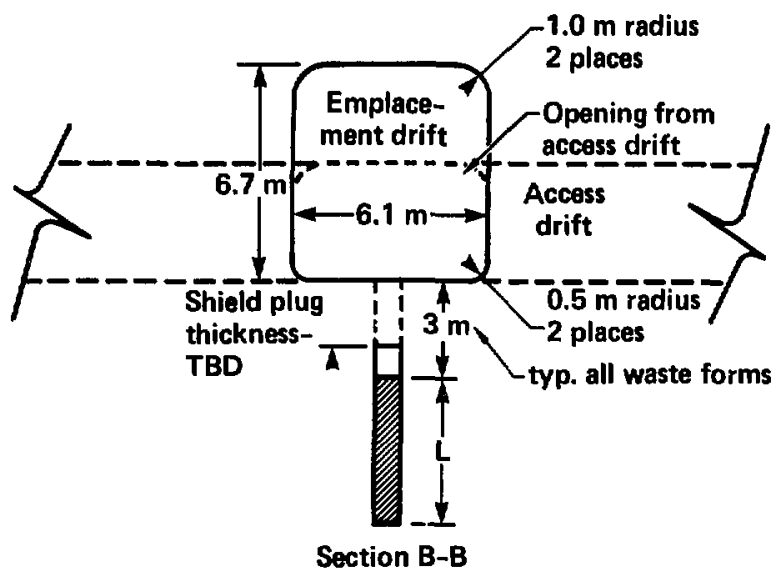

Figure 6. Detailed drift elevation view: vertical emplacement (section of Figure 4). 


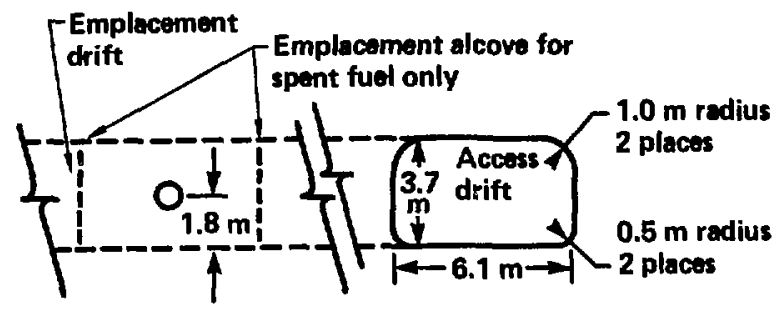

Note:

Perallel access drift for adjacont panel with emplacement drifts running to the right is located $\sim 30 \mathrm{~m}\left(100^{\prime}\right)$ to the right.

\section{Saction C-C}

Figure 7. Detalled drift plan view: horizontal emplacement (section of Figure 5).

fuel rods and intact assemblies. The canisters are placed into the emplacement holes with no additional metal containment barriers. It is expected that these canisters can be designed to meet the 300-to-1000-year containment requirement using austenitic stainless steel as the canister material.

The need for an alternative design for SF arises not from the need to meet the containment design requirement, but rather from the need to meet the long term release-rate design requirement. Segregated phases within the $\mathrm{SF}\left(\mathrm{UO}_{2}\right)$ are considerably more soluble in water than the DHLW and CHLW glass-waste forms. Bare spent fuel is thus less likely to meet the postcontiinment period release rate design objective, but the Zircaloy cladding may be a barrier to the release. If ongoing testing proves that Zircaloy cladding is not a suitable release barrier, packing may be required (Oversby, 1983). Therefore, the alternate $\mathrm{SF}$ waste-package designs employ a packing material around the canister designed to reduce the release rate (after the overpack has corroded through) by controlling water flow and sorbing radionuclides. The proposed packing material design consists of an outer low-permeability container of packing material, approximately $15 \mathrm{~cm}$ thick, consisting of crushed and pressed tuff, and perhaps containing a binder.

\section{Alternative Designs That Have Been Eliminated}

Three basically different waste package design concepts were considered earlier in the program and have been eliminated from consideration for the NNWSI repository. They are the self-shielded package, the titanium-shell-over- steel package, and the three-in-one package. They are discussed below.

Self-Shielded Package (Westinghouse, 1983). This design, proposed by Westinghouse Electric Corporation, consisted of cast or gray iron overpacks with sufficient thickness to provide radiation shielding to allow contact handling. Such a package design would have the many advantages associated with minimizing the personnel shielding that would be required for handling. However, calculations indicated that the walls would have to be approximately $30 \mathrm{~cm}$ thick to accomplish this task. This made the package more expensive and many times heavier than our present selected reference package (Westinghouse, 1983). It did not appear that the advantages associated with the self-shielding would compensate for the additional expense associated with fabricating the package and for handling the extra weight.

Titanium-Shell-Over-Steel Package (Westinghouse, 1983). This waste package was designed to combine the corrosion resistance of titanium with the strength of the relatively inexpensive carbon steel. The design involves covering a thick, strong carbon steel package with a thin, corrosion-resistant titanium shell. It was initiated primarily for service below the water table where the package is subjected to a high hydrostatic head. Initial corrosion information indicates that very thin shells (1 $\mathrm{mm}$ or less) of titanium would be sufficient to provide the corrosion resistance needed to meet the 300-to-1000year containment requirement, and steel thicknesses of several centimeters or more would be 
required to prevent crushing by the hydrostatic head present in repositories below the water table. Thick titanium walls would be far too expensive to be used to meet these strength requirements. Thus, the combination package, using a thin external shell of titanium for corrosion resistance and a thick inner shell of steel for strength, was designed to meet both requirements in a cost effective manner. The critical difference introduced by the NNWSI repository candidate horizon is that it is located above the water table and thus there is no hydrostatic head and the groundwater has a relatively low corrosivity. Therefore, thick walls are not required to prevent crushing, and corrosion conditions are not severe. Thus, the simpler designs presented in this report, made of stainless steel with a $1-\mathrm{cm}-$ wall thickness will meet the requirements in a more cost-effective manner.

Three-in-One Package. This package concept explored the possible economy of placing three DHLW canisters in a triangular array in one overpack. In this way more canisters would be placed in a particular hole and fewer overpacks would have to be fabricated. However, a preliminary cost study of this design variation indicated that there would be little if any economy in this design. In fact, for some scenarios, it was considerably more expensive than individually overpacked canisters. It was therefore discarded since the large changes that it introduced in 1 . ackage diameters and weights were not justified by economics.

\section{Regulatory Requirements for Waste Package Design}

The regulatory requirements that the waste packages must satisfy are given in 10 CFR Part 60 (NRC, 1983). They are summarized below.

\section{Containment}

Regulation: "60.113 Performance of particular barriers after permanent closure." "The engineered barrier system shall be designed, assuming anticipated processes and events, so that: (A) Containment of HLW within the waste packages will be substantially complete for a period to be deterinined by the Commission taking into account the factors specified in 60.113 (b) provided, that such period shall be not less than 300 years nor more than 1000 years after permanent closure of the geologic repository." (NRC, 1983)

Discussion: All the waste package designs rely on a corrosion-resistant metal barrier to meet the containment design requirement. This primary containment barrier may either be the canister or the overpack, depending on the specific design. The thickness of metal needed to meet this requirement will depend on the corrosion rate and mecilanism in the expected tuff environment. The corrosion rate and mechanism will deperid on a number of parameters including the state of stress, the type of metal and, the microstructure, the number and characteristics of defects, the temperature history, radiolysis effects, galvanic effects, and the groundwater characteristics. All of these parameters will have to be taken into consideration in modeling and predicting the containment life of the package.

To meet this requirement the waste package must also be strong enough that it will not be crushed by hydrostatic or lithustatic pressures. Since the NNWSI repository is above the water table, there is no hydrostatic head, but there may be some lithostatic pressure due to rnck sloughing on the packages. Earthquake loads must also be considered.

\section{Release Control}

Regulation: "60.113 Performance of particular barriers after permanent closure." "The engineered barrier system shall be designed, assuming anticipated processes and events, so that:...(B) The release rate of any radionuclide from the engineered barrier system following the containment period shall not exceed one part in 100,000 per year of the inventory of that radionuclide calculated to be present at 1000 years following permanent closure, or such other fraction of the inventory as may be approved or specified by the Commission; provided, that this requirement does not apply to any radionuclide which is released at a rate less than $0.1 \%$ of the calculated total release rate limit. The calculated total release rate limit shall be taken to be one part in 100,000 per year of the inventory of radioactive waste, originally emplaced in the underground facility, that remains after $\mathbf{1 0 0 0}$ years of radioactive decay." (NRC, 1983)

Discussion: The primary approach to ensuring that this design requirement is met is to use a low solubility waste form. This, in combination with the low groundwater seepage rate at the NNWSI repository, generally ensures a radionuclide release rate that meets this requirement. The low waste form solubility is accomplished for DHLW and CHLW by incorporating the waste into a low solubility glass. For spent fuel rods, release 
can be effectively reduced by keeping intact the very corrosion-resistant Zircaloy cladding surrounding the fuel. The release rate from spent fuel without cladding is considerably greater than for the glass waste forms and may not meet this requirement by itself. Therefore, if it is determined that the Zircaloy cladding will not provide a sufficient barrier, a packing material will be emplaced around the canister. The packing material may be made of crushed, compressed tuff possibly mixed with a binder material and will be designed to control water flow and sorb the radionuclides suff:ciently so that the release requirement is met.

\section{Criticallty Control}

Regulation: "60.131 General design criteria for the geologic repository operations area." "(b) Structures, systems, and components important to safety." "(7) All systems for processing, transporting, handling, storage, retrieval, emplacement, and isolation of radioactive waste shall be designed to ensure that a nuzlear criticality accident is not possible unless at least two unlikely, independent, and concurrent or sequential changes have occurred in the conditions essential to nuclear criticality safety. Each system shall be designed for criticality safety under normal and accident conditions. The calculated efiective multiplication factor $\left(k_{\text {ett }}\right)$ must be sufficiently below unity to show at least a $5 \%$ margin, after allowance for the bias in the method of calculation and the uncertainty in the experiments used to validate the method of calculation." (NRC, 19183)

Disscussion: The neutron multiplication factor, $\mathrm{k}_{\text {eff }}$, will be calculated for all the designs and emplacemert configurations selected. However, it is anticipated that all the waste package designs will meet criticality requirements of 10 CFR 60 for either emplacement configuration.

In postulating potential configurations for evaluation, it is useful to think in terms of three time frames: (1) assembly, emplacement, and short times (decades) thereafter; (2) intermediate times after emplacement (hundreds of years); and (3) very long times (up to thousands of years after emplacement). We expect that, in the short term, the nominal geometry at assembly and emplacement will exist. As time passes, first the canister and then the space frame corrodes, after which the fuel rod cladding fails, releasing the fuel pellets, and finally the fuel pellets disintegrate to powder. At all times the potential for water intrusion will be considered. These scenarios give rise to many potential configurations, some dry, and some flooded. For all credible configurations, the effec- tive neutron multiplication factor $\left(\mathrm{k}_{\mathrm{eft}}\right)$ will be shown to be less than 0.95 unless at least two unlikely, independent, and concurrent or sequential changes have occurred in the conditions essential to nuclear criticality safety.

\section{Retrievability of Waste}

Regulation: "60.111 Performance of the geologic repository operations area through permanent closure." "(b) Retrievability of waste. (1) The geologic repository operations area shall be designed to preserve the option of waste retrieval throughout the period during which wastes are being emplaced and, thereafter, until the completion of a performance conf:rmation program and Commission review of the information obtained from such a program. T) satisfy this objective, the geologic repository operations area shall be designed so that any or all of the emplaced waste could be retrieved on a reasonable schedule starting at any time up to 50 years after waste emplacement operations are initiated, unless a different time period is approved or specified by the Commission." "(3) For purposes of this paragraph, a reasonable schedule for retrieval is one that would permit retrieval in about the same time as that devoted to construction of the geologic repository operations area and the emplacement of wastes." (NRC, 1983)

Discussion: To meet this requirement, the waste canister, pintle assembly, pintle attachment welds, and waste package emplacement configuration must be designed so that they are compatible with both the initial emplacement operations as well as the retrieval operations.

\section{Transportation and Handling}

Regulations: "60.135 Criteria for the waste package and its components: (a) High-level-waste package design in general:" "(2) The design shall include but not be limited to consideration of the following factors: solubility, oxidation/reduction reactions, corrosion, hydriding, gas generation, thermal effects, mechanical strength, mechanical stress, radiolysis, radiation damage, radionuclide retardation, leaching, fire and explosion hazards, thermal loads, and synergistic interactions." (b) Specific criteria for HLW package design." "(3) Handling: Waste packages shall be designed to maintain waste containment during transportation, emplacement and retrieval." (NRC, 1983)

"60.131 General design criteria for the geologic repository operations area." "(b) Structures, systems, and components important to safety." 
“(2) Protection against dynamic effects of equipment failure and similar events: The structures, systems and components important to safety shall be designed to withstand dynamic effects such as missile impacts, that could result from equipment failure, and similar events and conditions that could lead to a loss of their safety functions. (3) Protection against fires and explosions, (i) The structures, systems, and components important to safety shall be designed to perform their safety functions during and after credible fires or explosions in the geologic repository operations area." (NRC, 1983)

Discussion: The regulation governing the transport of high-level radioactive materials is covered in 10 CFR 71 (NRC, 1982). This regulation presents numerous requirements that the shipping container must meet, with the waste canister inside. However, these shipping requirements will apply almost exclusively to the shipping cask and will have little effect on the design of the waste canister, unless the canister comprises the inner container of the required double container for shipping casks. The regulation governing the handling of the canisters and overpacks outside of the shipping casks at the repository is covered in 10 CFR 60 , which is quoted above. This regulation requires that the canisters be safe to handle in the repository under normal and credible accident conditions. However, unlike $10 \mathrm{CFR} 71$, it does not specify what these conditions are. Therefore, us. ing $10 \mathrm{C} F R 71$ as a guide, a more specific set of repository handling requirements has been formuIated to guide the waste package design effort. It is assumed that handling the waste package within the repository should be made as safe as transporting the waste to the repository, considering the differences in expected handling loads and credibie-accident scenarios. Therefore, ths requirements should be similar to the transportation requirements presented in 10 CFR 71 for highly radioactive material. .

Normal Handling Conditions. The first handling requirement is that the waste package must be designed to sustain the normal stresses resulting from transporting, handling, emplacing, and retrieving waste while preserving the package's capability to contain the waste. Such requirements are treated in 10 CFR 71, Subpart C - Package Standards. They are as follows:

"71.31 General standards for all packaging:

(a) Packaging shall be of such materials and construction that there will be no significant chemical, galvanic, or other reaction among the packaging components, or between the packaging components and the package contents.

(b) Packaging shall be equipped with a positive closure which will prevent inadvertent opening.

(c) Lifting devices:

(1) If there is a system of lifting devices which is a structural part of the package, the system shall be capable of supporting three times the weight of the loaded package without generating stress in any material of the packaging in excess of its yield strength.

(2) Each lifting device which is a structural part of the package shall be so designed that failure of the device under excessive load would not impair the containment or shielding properties of the package." (NNWSI is not designing to this requirement because the pintle is stronger than the canister.)

"71.32 Structural standards for type B and large quantity packaging:

Packaging used to ship a type B or a large quantity of radioactive material, as defined in 71.4 $(q)$ and $(f)$, shall be designed and constructed in accordance with the structural standards of this section.

(a) Load resistance: Regarded as a simple beam supported at its ends along any major axis, packaging shall be capable of withstanding a static load, normal to and uniformly distributed along its length, equal to 5 times its fully loaded weight, without generating stress in any material of the packaging in excess of its yield strength.

(b) External pressure: Packaging shall be adequate to assure that the containment vessel will suffer no loss of contents if subjected to an external pressure of 25 pounds per square inch gauge."

Credible Accident Conditions. The waste package must also be designed so that it can be handled safely under credible-accident conditior.s. In general, the credible-accident conditions place the most severe set of requirements on the package design, and if these requirements can be met, the package should easily meet the normal handling requirements. The credible-accident condition requirements of $10 \mathrm{CFR} 71$ are presented as follows:

Regulation: 10 CFR 71, Appendix BHypothetical Accident Conditions; 
"The following hypothetical accident conditions are to be applied sequentially, in the order indicated, to determine their cumulative effect on a package or array of packages. (NNWSI has not analyzed the package's ability to resist the cimulative effects of the three accident conditions, only the effects of each individual accident scenario.)

(1) Free Drop: A free drop through a distance of 30 feet onto a flat essentially unyielding horizontal surface, striking the surface in a position for which maximum damage is expected.

(2) Puncture: A free drop through a distance of 40 inches striking in a position for which maximum damage is expected, the top end of a vertical cylindrical mild steel bar mounted on an essentially unyielding horizontal surface. The bar shall be 6 inches in diameter, with the top horizontal and its edge rounded to a radius of not more than one-quarter inch, and of such a length as to cause maximum damage to the package, but not less than 8 inches long. The long axis of the bar shall be perpendicular to the unyielding horizontal surface.

(3) Thermal: Exposure to a thermal test in which the heat input to the package is not less than that which would result from exposure of the whole parkage to a radiation environment of $1,475^{\circ} \mathrm{F}\left(800^{\circ} \mathrm{C}\right)$ for 30 minutes with an emissivity coefficient of 0.9 assuming the surfaces of the package have an absorption coefficient of 0.8 . The package shall not be cooled artificially until 3 hours after the test period unless it can be shown that the temperature on the inside of the package has begun to fall in less than 3 hours.

(4) Water Immersion (fissile material packages only): Immersion in water to the extent that all portions of the package to be tested are under at least 3 feet of water for a period of not less than 8 hours."

\section{Labeling}

Regulation: "'60.135 Criteria for the waste package and its components." "(b) Specific criteria for HLW package design." "(4) Unique identification: $A$ label or other means of identification shall be provided for each waste package. The identification shall not impair the integrity of the waste package and shall be applied in such a way that the information shall be legible at least to the end of the period of retrievability. Each waste package identification shall be consistent with the waste package's permanent written records." (NRC, 1983)

\section{Desirable Design Features}

There are a number of design features that are not specifically identified in 10 CFR 60 , but which would be desirable to incorporate in the waste package designs. They are listed below:

Standardization. The waste package designs will use Federal and commercial standards and standardized components whenever possible. This includes standardizing such fixtures as pintles for all the packages as well as using standard pipe sizes and materials for the fabrication of the canisters and the horizontal borehole liners. Such standardization will simplify the operation of the repository.

Design Simplicity and Fabricability. The waste package will be designed with an emphasis on simplicity and ease of fabrication, without compromising the performance requirements. This approach should improve the reliability and predictability of the package performance.

Technical Conservatism. The waste package designs will be technically conservative. This will be accomplished by using proven materials, adequate safety factors, thorough and accurate analyses, prototype testing, and quality assurance procedures compatible with 10 CFR 60 .

Use of Conventional Materials and Fabrication Techniques. Emphasis will be placed on using conventional materials and reliable and wellunderstood fabrication techniques.

Repository Interface Requirements. The package will be made compatible with all of the waste processing, transportation, and repository operations.

Cost Effectiveness. The package will be designed to be cost effective without compromising design requirements.

\section{Conceptual Waste Package Configurations and Dimensions}

This section presents reference and alternate conceptual waste package designs for the three high-level waste forms - SF, CHLW and WVI DHLW - for vertical or horizontal emplacement configurations. The dimensions given on the drawings are expected to be within $10 \%$ of the final design dimensions (see Table 5). The reference waste canister material is austenitic stainless steel, 
Table 5. Reference and alternative design dimensions (cm) for NNWSI waste packages for vertical or horizontal emplacement.

\begin{tabular}{|c|c|c|c|c|}
\hline \multirow[b]{2}{*}{ Canister } & \multicolumn{2}{|c|}{ Spent Fucl } & \multirow{2}{*}{$\frac{\text { WVIDHLW" }}{\text { Ref }}$} & \multirow{2}{*}{$\frac{\text { CHLW" }}{\text { Ref }}$} \\
\hline & $\overline{\operatorname{Ref}}$ & $\overline{\text { Alt }}$ & & \\
\hline Diameter & 70 & 70 & 61 & 31 \\
\hline Length & $400-475$ & 40r: $\cdots$ & 300 & 300 \\
\hline Thkckness & 1 & 1 & 0.95 & 0.95 \\
\hline
\end{tabular}

\section{Overpack}

Diemeter

Length

Thkckness

Packing

Diemeter
Length
Material
Thickness

Canister for spent

fuel hardware

\begin{tabular}{lccccc} 
Dismeter & 70 & - & - & - \\
Length & 324.5 & - & - & - \\
Thickness & 1 & - & - & - \\
\hline
\end{tabular}

¿No alternative designs.

but a more detailed discussion of the selection of materials anc the selection issues is given in the next section. The designs are the same for the reference vertical emplacement or alternative horizontal emplacement.

\section{Conceptual Waste Package Designs for Spent Fuel}

The reference emplacement configuration for $\mathrm{SF}$ is vertical emplacement in a canister without a packing material. Drawings of the SF canisters for vertical and horizontal emplacement are shown in Figures 8 to 10 . For this canister design, three lengths are used to accommodate BWR and PWR fuel rods both in consolidated and boxed form. The same diameter accommodates different thermal loading densities for each configuration. The different lengths are needed to accommodate the variety of fuel rod lengths used by different reactors.

The alternative design of an SF canister emplaced vertically in a packing material container is shown in Figure 11. For this emplacement mode it is planned that the packing material will be preformed and encased in a steel container to facilitate the emplacement operation. The reference pintle design is the same design as that used for the WV/DHLW and CHLW pour canisters.

Spent fuel hardware left over from consolidation operations (spacers, tie plates, lifting bails, etc.) will be placed in $70-\mathrm{cm}$-diameter by $324.5-\mathrm{cm}$ long canisters of the same design used for spent fuel.

\section{Conceptual Waste Package Designs for Commercial High Level Waste}

The CHLW pour canister is $300 \mathrm{~cm}$ long and has a 32-cm outer diameter. It was assumed to have the same length as the WV/DHLW canister and a diameter consistent with the emplaced package meeting the temperature-design criteria for the waste forn. The diameter was established using preliminary thermal calculations for a repository areal power density (APD) of $57 \mathrm{~kW} /$ acre, but thermal calculations indicate the possibility of either some upward modification of this APD, a 


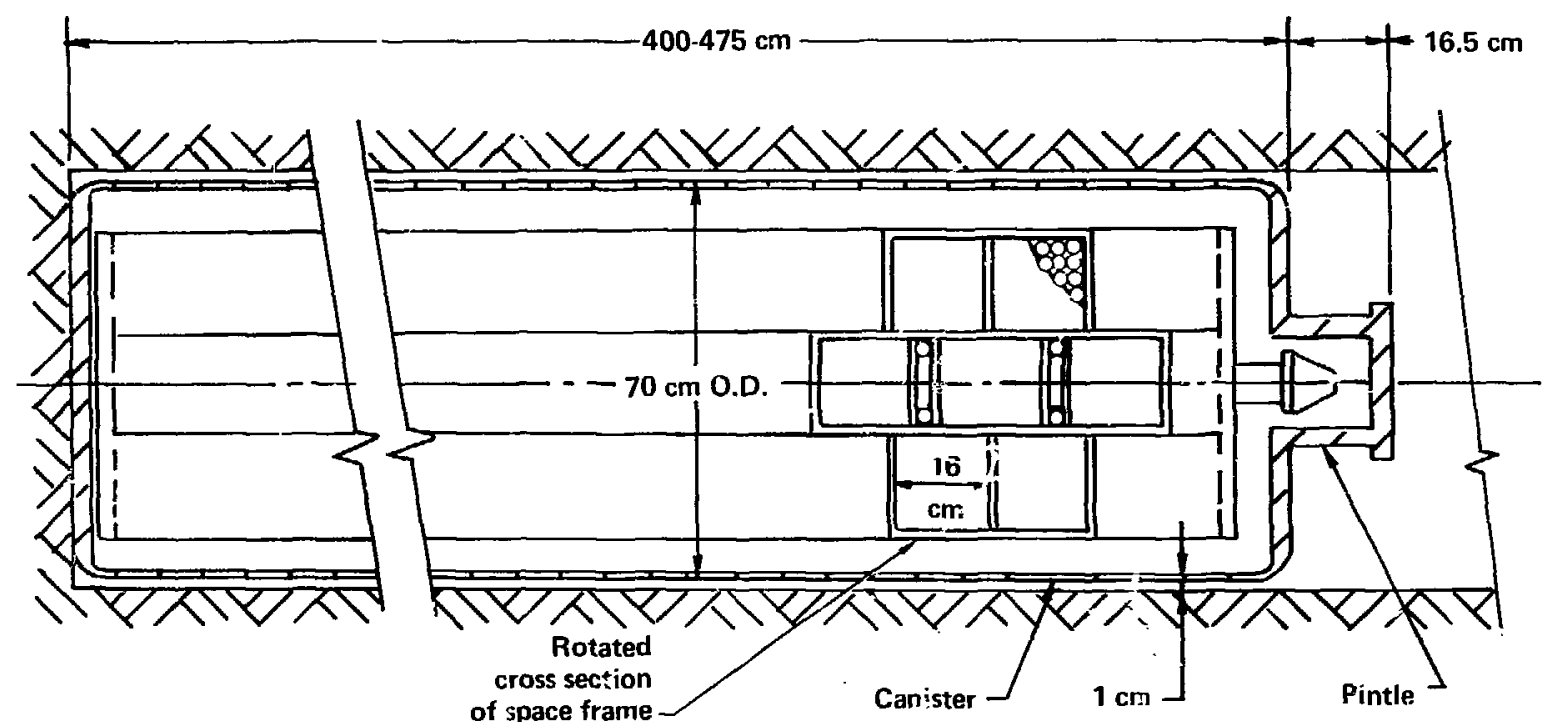

\section{Accepts:}

Consolidated, 10 yr, HBU, ${ }^{*} 12$ assems $\times 280 \mathrm{w}=3360 \mathrm{w}$ Consolidated, 10 yr, ABU, 14 assems $X 190 \mathrm{w}=2660 \mathrm{w}$

Consolidated, 5 yr, ABU, 12 assems $\times 280 \mathrm{w}=3360 \mathrm{w}$

Intact, $\quad 10 \mathrm{yr}$, AEU, 7 assems $\times 190 \mathrm{w}=1330 \mathrm{w}$

Intact, $\quad 5 \mathrm{yr}, \mathrm{ABU}, \quad 7$ assems $\times 280 \mathrm{w}=1960 \mathrm{w}$

Intact, $\quad 5 \mathrm{yr}, \mathrm{HBU}, \quad 7$ assems $\times 435 w=3045 \mathrm{w}$

${ }^{*} \mathrm{HBU}=$ high burn-up

$A B U$ = average burn-up

Figure 8. BWR spent fuel canister, 7/14 assemblies verticaily emplaced. 


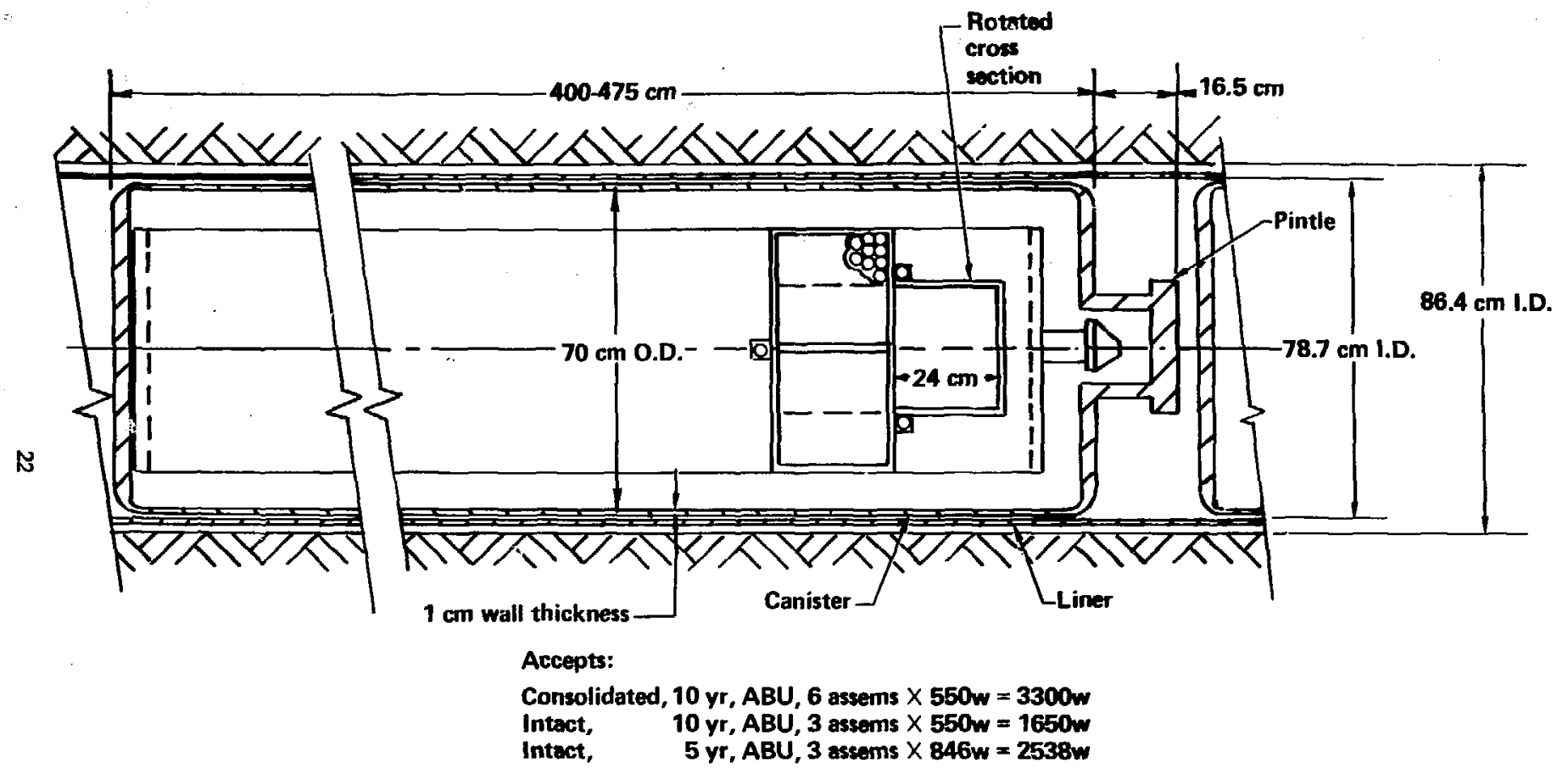

Figure 9. PWR spent fuel canister, $3 / 6$ assemblies horizontally emplaced. 


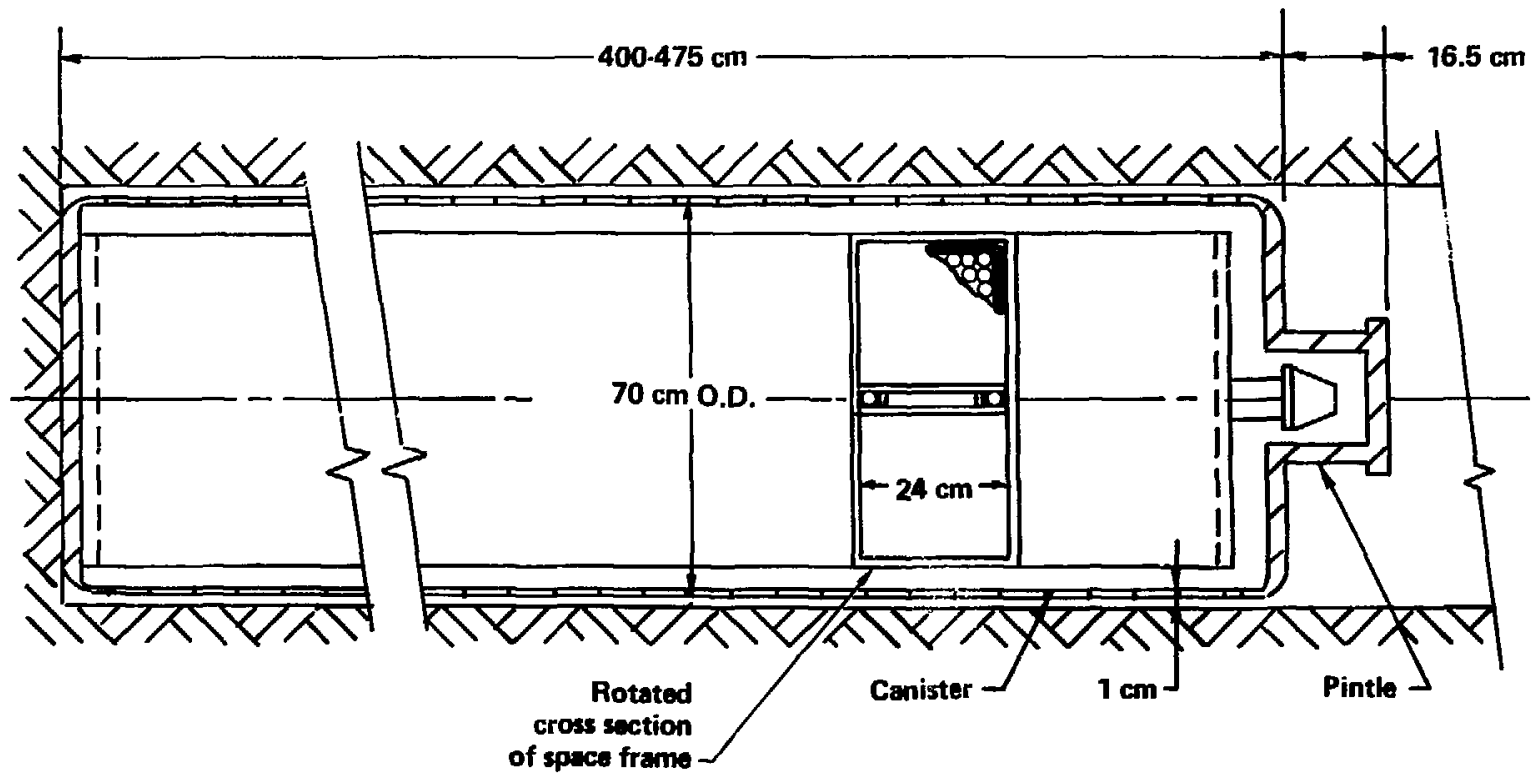

Accepts:

Consolidated, $10 \mathrm{yr}, \mathrm{HBU}, 4$ assems $X 846 \mathrm{w}=3384 \mathrm{w}$

Consolidated, 5 yr, ABU, 4 assoms $\times 846 \mathrm{w}=3384 \mathrm{w}$

Intact, $\quad 5 \mathrm{yr}, \mathrm{HBU}, 2$ assems $\times 1316 \mathrm{w}=2632 \mathrm{w}$

Figure 10. PWR spent fuel canister, 2/4 assemblies, vertically emplaced. 


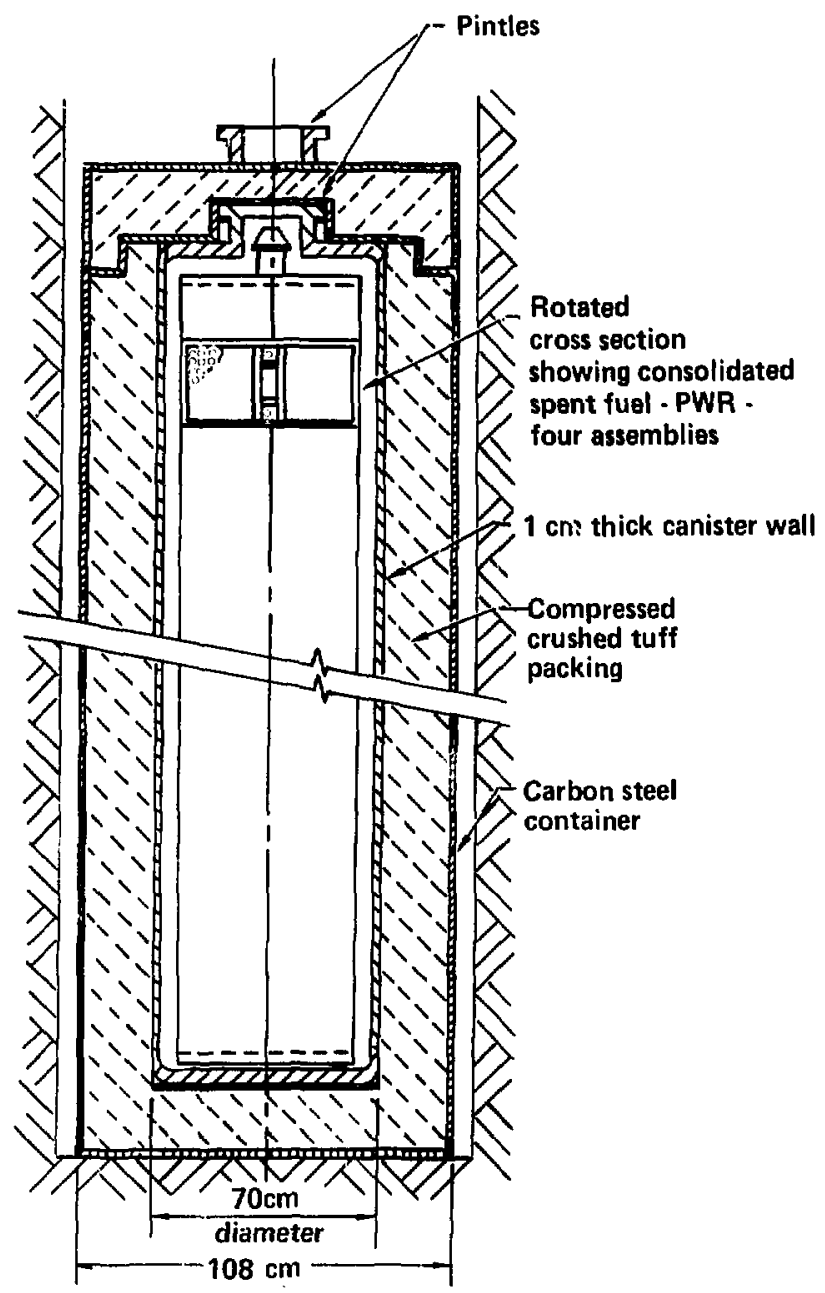

Figure 11. Alternative design for consolidated spent fuel waste packages if packing is needed to reduce reiease rate.

larger canister diameter, or for a higher waste loading. The reference emplacement configuration is vertical emplacement with an overpack (see Figure 12). For either configuration the overpack: has an outside diameter of $36 \mathrm{~cm}$ and an overall length (including pintle) of $324.5 \mathrm{~cm}$.
Conceptual Waste Package Designs for West Valley/Defense High Level Waste

The WV/DHLW pour canister is $300 \mathrm{~cm}$ long and has a $61-\mathrm{cm}$ outer diameter. The reference emplacement configuration is vertical emplacement 
with an overpack. Figure $\mathbf{1 2}$ is a drawing of the WV/DHLW canister overpacked and emplaced vertically. For either configuration the overpack has an outside diameter of $70 \mathrm{~cm}$ and an overall length (including pintle) of $324.5 \mathrm{~cm}$.

\section{Candidate Waste Package Materials}

\section{Metallic Materials}

Functional Requirements for Metallic Waste Package Components. The metallic components of the waste package (the canister, pintle, overpack, and hole liner), must be designed so that the

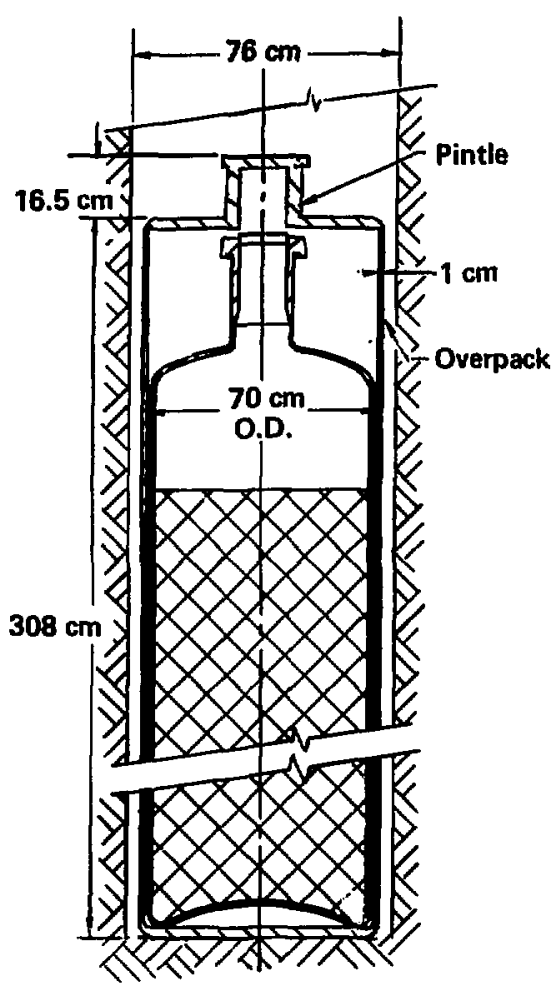

WV/DHLW (defense high-level waste) package emplaced in vertical borehole waste package meets the requirements for containment, retrievability, transportation and haridling, labeling, and desirable design considerations. In summary, the metals help provide a strong container for transportation and handling, a corrosion-resistant barrier for the 300-to-1000year containment requirement, and a steel hole liner for horizontal emplacement to keep the hole free of sloughed rock for emplacement and retrieval operations.

Metals Nomination (Russell et al., 1983 and McCright et al.,1983). A total of 17 different promising metallic materials were reviewed as

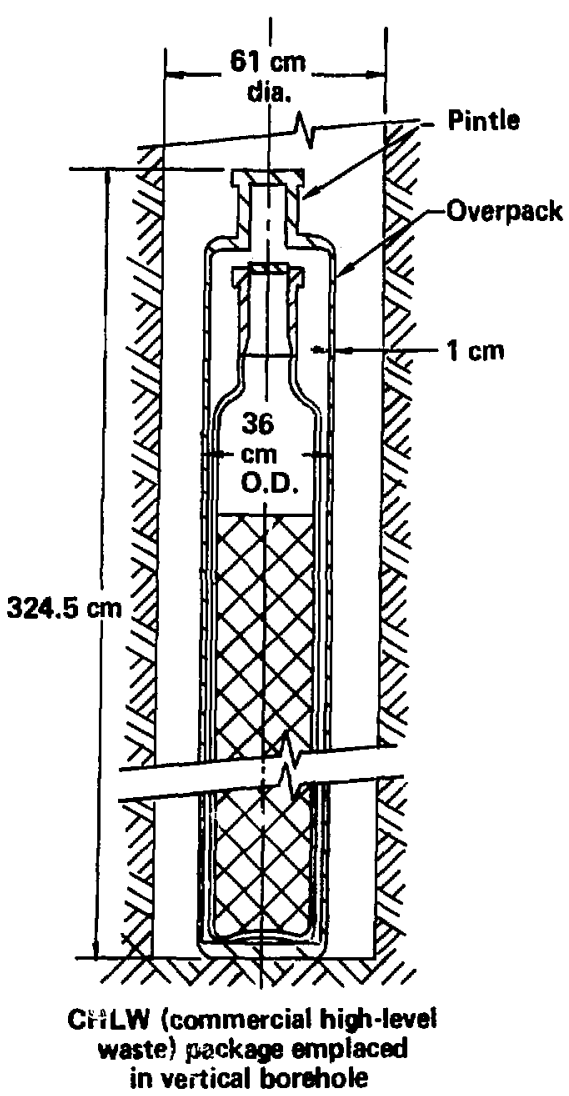

Figure 12. Conceptual designs for WVIDHLW and CHLW canisters, vertically emplaced. 
candidates for the canister, overpack, and borehole liner. The following categories were includ_d in the review: austenitic stainless steels, ferritic stainless steels, titanium alloys, zirconium alloys, copper-nickel alloys, low-carbon steels, and cast irons. These metals are all commercially available (see Table 6). From this list, five materials were selected for further evaluation.

The selection procedure involved determining and evaluating the properties considered to be

Table 6. Candidate metals for overpacks.

\begin{tabular}{|c|c|}
\hline $\begin{array}{l}\text { Commercial material } \\
\text { designation }\end{array}$ & Chemical composition (wt \%) \\
\hline $\begin{array}{l}\text { 1. AISI } 1020 \mathrm{cs} \\
\text { UNS G10200 }\end{array}$ & C0.18-0.23, Mn 0.3-0.6, P 0.04 max, S0.05 max, Fe rem \\
\hline 2. ASTM A537B cs & $\begin{array}{l}\text { C0.24 max, Mn 0.7-1,35, P0.035 max, S0.04 max, Si 0.15- } \\
0.5, \text { Cr } 0.25 \text { max, Ni } 0.25 \text { max, Mo } 0.08 \text { max, Cu } 0.35 \\
\text { max, Fe rem }\end{array}$ \\
\hline $\begin{array}{l}\text { 3. AISI } 409 \text { ss } \\
\text { UNS } \$ 40900\end{array}$ & $\begin{array}{l}\text { C } 0.08 \text { max, Cr 10.5-11.75, Mn } 1.0 \text { max, Ni } 0.05 \text { max, P } \\
0.04 \text { max, } 50.045 \max \text { Si } 1.0 \text { max, Ti } 6 \times C \text { min }-0.75 \\
\text { max, Fe rem }\end{array}$ \\
\hline $\begin{array}{l}\text { 4. } 26 \mathrm{Cr}-1 \text { Mo st } \\
\text { UNS S44626 }\end{array}$ & 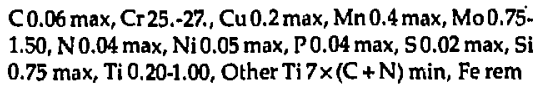 \\
\hline $\begin{array}{l}\text { 5. AISI } 304 \text { L } 55 \\
\text { UNS S30403 }\end{array}$ & $\begin{array}{l}\text { C } 0.030 \text { max, Cr } 18.00-20.00 \text {, Mn } 2.00 \text { max, Ni } 8.00-12.00 \text {, } \\
\text { P } 0.045 \text { max, S } 0.030 \text { max, Si } 1.00 \text { max, Fe rem }\end{array}$ \\
\hline $\begin{array}{l}\text { 6. AISI } 321 \mathrm{ss} \\
\text { UNS S32100 }\end{array}$ & $\begin{array}{l}\text { C } 0.08 \text { max, Cr 17.00-19.00, Mn } 2.00 \text { max, Ni } 9.00-12.00, P \\
0.045 \text { max, S0.030 max, Si } 1.00 \text { max, Ti } 5 \times \text { C min, Fe rem }\end{array}$ \\
\hline $\begin{array}{l}\text { 7. AISI 316L ss } \\
\text { UNS S31603 }\end{array}$ & $\begin{array}{l}\text { C 0.030 max, Cr 16.00-18.00, Mn } 2.00 \text { max, Mo 2.00-3.00, } \\
\mathrm{Ni} 10.00-14.00, \mathrm{P} 0.045 \text { max, S0.030 max, Si } 1.00 \text { max, Fe } \\
\text { rem }\end{array}$ \\
\hline $\begin{array}{l}\text { 8. AISI 317L ss } \\
\text { UNS S31703 }\end{array}$ & $\begin{array}{l}\text { C0.030 max, } \mathrm{Cr} 18.00-20.00, \mathrm{Mn} 2.00 \max , \mathrm{Mo} 3.00-4.00 \text {, } \\
\mathrm{Ni} 11.00-15.00, \mathrm{P} 0.045 \text { max, S0.030 max, Si } 1.00 \text { max, Fe } \\
\text { rem }\end{array}$ \\
\hline
\end{tabular}

9. Nitronic $33 \mathrm{C} 0.08$ max, $\mathrm{Cr} 17.00-19.00, \mathrm{Mn} 11.50-14.50, \mathrm{~N} 0.02-0.40$, UNS S2400 Ni 2.50-3.75, P 0.060 max, S 0.030 max, Si 1.00 max, Fe

10. IS700 UNS N08700 rem

C 0.04 max, Ni 24.0-26.0, Cr 19.0-23.0, Mo 4.3-5.0, Nb $8 \times C$ min-0.04 max, Si 1.0 max, Mn 2.0 max, $P 0.04$ max, S 0.03 max, Cu 0.5 max, Fe rem

11. Ferralium 255 C 0.04 max, Cr 24.0-27.0, Mo 2.0-4.0, Ni 4.5-6.5, Si 1.0 UNS 532550

12. Incoloy 825 UNS N08825

13. Inconel 625 UNS N06625

14. Ti Grade 2 UNS R50400 $\max , M n 1.5 \max , N 0.10-0.25, \mathrm{Cu} 1.5-2.5$, Fe rem Al 0.2 max, C0.05 max, Cr 19.5-23.5, Cu 1.5-3.0, Mn 1.0 $\max , \mathrm{Mo} 2.5-3.5, \mathrm{Ni} 38.0-46.0, \mathrm{~S} 0.03$ max, Si 0.5 max, Ti 0.6-1.2, Fe rem

Al 0.40 max, C 0.10 max, Nb 3.15-4.15, Cr 20.0-23.0, Fe 5.0 max, Mn 0.50 max, Mo 8.0-10.0, P 0.015 max, S 0.015 max, Si 0.50 max, Ti $0.40 \max$, Ni rem

15. Ti Grade 12

16. $\mathrm{Zr} 702$ UNS R60702

17. Cupronickel $70 / 30$ UNS C71590

C 0.10 max, H 0.015 max, Fe $0.30 \max , N 0.03$ max, O 0.25 max, Ti Rem

N 0.03 max, C 0.08 max, H0,015 max, Fe 0.3 max, O0.25 $\max , \mathrm{Mo} 0.2-0.4, \mathrm{Ni} 0.6-0.9$, Ti Rem

C 0.05 max, H 0.005 max, Hf 4.5 max, N0.025 max, Zr + Hf 99.2 min, $\mathrm{Fe}+\mathrm{Cr} 0.2 \max$

Al 0.002 max, As 0.001 max, Bi 0.001 max, C 0.03 max, Co 0.05 max, Cu 67.0 min, $\mathrm{Hg} 0.0005$ max, Fe 0.005 max, Mn 0.001 max, Ni 29.0-33.0, P 0.001 max, Pb 0.001 max, S0.003 max, Sb0.001 max, Si 0.02 max, Sn 0.001 max, Ti 0.001 max, $\mathrm{Zn} 0.001$ max, Other $\mathrm{Ag}$ included in $\mathrm{Cu}, \mathrm{Co}$ included in $\mathrm{Ni}, \mathrm{Cu}+$ all named elements $99.5 \mathrm{~min}$ 
important. These fell under the four general categories:

1. General and local corrosion resistance.

2. Material and fabrication costs.

3. Desired and required mechanical properties.

4. Weldability.

The desired quantitative values for candidate metals properties are summarized in Table 7 .

The corrosion requirement is based on the economy of using a canister/overpack wall thickness no greater than that required for transportation and handling. This handling thickness iequirement is estimated to be approximately a $1-\mathrm{cm}$ (0.39 in)-wall thickness. A corrosion rate of $1 \mathrm{mil} /$ year $(0.0025 \mathrm{~cm} /$ year $)$ would correspond to a corrosion depth of 0.76 to $2.54 \mathrm{~cm}(0.3$ to $1.0 \mathrm{in})$ in the 300 -to-1000-year containment period. Thus, a $1-\mathrm{cm}$ thickness will fall between these two limits. The yield strength at $800^{\circ} \mathrm{C}$ is based on the requirement that the package be able to contain the waste when exposed to a credible fire accident. The impact strength is required to meet the puncture and drop accident requirements. The ductility requirement at $-18^{\circ} \mathrm{C}$ is to ensure that the canister will not fracture when dropped at the low temperatures frequently experienced in the winter at Yucca Mountain. The weldability requirement is to ensure that the material can be welded reliably and economically. The cost requirement is to ensure that the material is cost effective.

In the selection process, general and local corrosion data were obtained from the available literature and preliminary LLNL corrosion tests. All important corrosion mechanisms to which each metal would be subjected in the Yucca Mountain repository environment were considered. These are: general corrosion; pitting, crevice, transgranular and intergranular corrosion; galvanic corrosion; and stress corrosion cracking (McCright et al., 1983). Information about the other properties listed above was readily available for each of the materials being considered because the mate- rials are commonly used in industrial applications, and such information is generally needed. A detailed description of the selection process is given by McCright et al. (1983).

\section{Nonmetallic Waste Package Packing Materials}

A variet $y$ of functions have been described for packing materiais (intmerly called ' ackfill) that might be emplaced around waste package containers. These include reducing access of water to the container or waste form, modifying groundwater chemistry, limiting stress on or cushioning the package, and retarding the novement of nuclicies release ' trnm the waste form. The n.ateriais capable if performing tiese functions have the common drawback that their thermal conductivity is lower than the host rock and therefore the temperatures of all the components that they surround are raised. This adverse characteristic may require reduced waste loading in each package and therefore more packages with attendant increased costs and complexity.

In the unsaturated zone tuff environment, preliminary assessments indicate that a packing material should not be necessary around the borosilicate glass waste forms (Oversby, 1984). In the case of spent fuel the need for packing material will depend on the effectiveness of the fuel cladding in reducing the nuclide relcase rate and the dominant water flow mechanism in the near-field rock mass.

An investigation of the feasibility of fabricating preformed crushed tuff materials that might be preemplaced in disposal holes has been initiated. Small samples have been pressed using both crushed tuff alone and with a low percentage addition of a binder material. The thermal conductivity of thess sumples has been measured $(0.65 \mathrm{~W} /$ $\mathrm{mK}$ ) which is about $1 / 3$ that of dehydrated host rock (Oversby, 1984).

During 1984 to 1985, additinnal samples will be fabricated and tested for conductivity at appropriate temperatures and thermal gradients (Ballou, 1983).

Table 7. Key properties of candidate metals.

\begin{tabular}{ll}
\hline \multicolumn{1}{c}{ Attribute } & \multicolumn{1}{c}{ Desired value } \\
\hline Corrosion (general or local) & $1 \mathrm{mil}(0.00254 \mathrm{~cm}) /$ year maximum \\
Yield strength $\left(800^{\circ} \mathrm{C}\right)$ & $2,000 \mathrm{psi}(13.8 \mathrm{MPa})$ minimum \\
Impact strength & $15 \mathrm{ft}-1 \mathrm{~b}(20)$ charpy v-notch, minimum \\
Ductility at $\left(-18^{\circ} \mathrm{C}\right)$ & $25 \%$ elongation, minimum (annealed) \\
Weldability & As good as $304 \mathrm{~L}$ stainless steel \\
Cost (for $1-\mathrm{cm}$-thick plate) & $\$ 1 / \mathrm{in}^{3}\left(\$ 0.061 / \mathrm{cm}^{3}\right)$ \\
\hline
\end{tabular}




\section{Section II \\ Information Re: yuired to Demonstrate \\ Regulatury Compliance \\ by the Conceptual Waste Package Designs}

\section{Selection of Candidate Waste Package Containment Barrier Metals for the Tuf: Repository}

Five candidate metals have been selected from an initial list of $\mathbf{1 7}$ for conceptual design of canisters, overpacks, and borehole liners, and for use in corrosion tests under repository conditions (see Section I under "Candidate Waste Package Materials."). Important materials-properties data reflecting engineering design requirements for potential-candidate materials were considered in screening candidates.

\section{Nomination of Candidate Metals}

The 17 candidate metals that potentially met our design requirements are given in Table 6. These metal alloys fall in three categories: (1) ironbase alloys with a ferritic structure; (2) iron-base to nickel-base alloys with an austenitic structure; and (3) others, e.g., copper-, titanium-, and zirconium-base alloys. The list of metals was screened to yield the best five.

Iron-Base Alloys with a Ferritic Structure. The ferritic metals initially considered for this group are low-carbon steels, despite the fact that lowcarbon steels may have a high corrosion rate in the anticipated oxidizing environment of the repository. The redeeming properties of these steels are as follows: lowest overall unit cost; acceptable strength at room temperature and $800^{\circ} \mathrm{C}$; and good weldability. The two low-carbon steels that we considered are AISI 1020 steel and ASTM A537B steel. Carbon steel is the reference metal for borehole liners, based on its low cost and projected survival during the retrieval period.

Alloys of carbon steels containing chromium and molybdenum have increased corrosion resistance under oxidizing conditions. The ferritic alloy steels under consideration are expected to be resistant to attack by pitting and crevice corrosion as well as to stress corrosion cracking. The shortcomings of this group are low fracture toughness values as well as poor weldability. The ferritic alloy steels considered are AISI $409 \mathrm{Ti}$ stabilized stainless steel and $26 \mathrm{Cr}-1$ Mo stainless steel.
Iron-Base to Nickel-Base Alloys with an Austenitic Structure. The NNWSI reference canister/ overpack metal is austenitic stainless steel. The engineering properties of austenitic stainless steel are excellent with the exception of possible susceptibility to localized corrosion and to stress corrosion cracking in some alloys. If intergranular stress corrosion cracking is excessive for $304 \mathrm{~L}$ or 316L stainless steel in the tuff environment, other stabilized austenitic stainless steels such as $\mathbf{3 2 1}$ stainless steel, or a high-nickel austenitic alloy such as Incoloy 825 , are appropriate choices. If transgranular stress corrosion cracking is a problem, an alloy with greater than $20 \%$ nickel content, such as Incoloy 825 , is appropriate.

If pitting and/or crevice corrosion attack is excessive, an alloy with increased molybdenum, e.g., AISI 317L stainless steel or Incoloy 825, will increase the resistance to these forms of corrosion. All of the 300 series stainless steels should be manufactured in the extra-low carbon (0.02\% max) modification to avoid sensitization in the final topcap weld on canisters and overpacks.

Copper-, Titanium-, and Zirconium-Base Alloys. The titanium alloys are expected to be very resistant to conditions that may occur in a strong gamma radiation field. These alloys are also very resistant to localized forms of corrosion, but lose most of their mechanical strength at $800^{\circ} \mathrm{C}$. When compared with the other metals, cupronickel 701 30 has excellent engineering properties in all categories we consider important except for the formation of nitric acid in aqueous, radiolyzed environments, and strength at $800^{\circ} \mathrm{C}$. Zirconium alloys have proven performance in aqueous, radiolyzed environments, but exhibit low mechanical strengths at $800^{\circ} \mathrm{C}$ as well as marginal fracture toughness values at $-18^{\circ} \mathrm{C}$, and are the most costly of the candidate metals considered.

\section{Summary of Candidate Alloys}

Analysis of the data resulted in selection of the four highest ranking metals out of the 17 candidates for canisters or overpacks. Table 8 shows the scores and ranking of the candidates. AISI 1020 carbon steel was chosen for hole liners. Summary statements are given on these metals. 
Table 8. Ranking summary for candidate metals.

\begin{tabular}{|c|c|c|c|c|c|c|}
\hline $\begin{array}{c}\text { Material } \\
\text { designation } \\
\text { or composition }\end{array}$ & $\begin{array}{l}\text { Corrosion } \\
\text { resistance. }\end{array}$ & $\begin{array}{l}\text { Mechanical } \\
\text { properties }\end{array}$ & Weldability" & Cost $^{a}$ & Score: & Rank $^{b}$ \\
\hline AISI 1020 steel & 0 & 1 & 2 & 2 & 5 & 3 \\
\hline A537 steel & 0 & 2 & 1 & 2 & 5 & 3 \\
\hline 409 st. steel & 1 & 1 & 1 & 1 & 4 & 3 \\
\hline $26 \mathrm{Cr}-1 \mathrm{Mo}$ steel & 1 & 1 & 0 & 0 & 2 & 3 \\
\hline 304L st. steel & 1 & 2 & 2 & 2 & 7 & 1 \\
\hline 321 st. steel & 1 & 2 & 2 & 2 & 7 & 1 \\
\hline 316L st. steel & 1 & 2 & 2 & 2 & 7 & 1 \\
\hline 317L st, steel & 1 & 2 & 2 & 1 & 6 & 2 \\
\hline Nitronic 33 & 1 & 2 & 2 & 1 & 6 & 2 \\
\hline JS 700 & 2 & 2 & 0 & 1 & 5 & 3 \\
\hline Ferralium 255 & 1 & 2 & 1 & 1 & 5 & 3 \\
\hline Incoloy 825 & 2 & 2 & 2 & 1 & 7 & 1 \\
\hline Inconel 625 & 2 & 2 & 2 & 0 & 6 & 2 \\
\hline Ti Code 2 & 2 & 0 & 1 & 0 & 3 & 3 \\
\hline Ti Code 12 & 2 & 0 & 0 & 0 & 2 & 3 \\
\hline $2 \pi 702$ & 2 & 0 & 0 & 0 & 2 & 3. \\
\hline $\mathrm{Cu}-\mathrm{Ni} 70 / 30$ & 0 & 0 & 1 & 1 & 2 & 3 \\
\hline
\end{tabular}

${ }^{2} 0=$ some disadvantages, 1 = suitable, 2 = superior.

${ }^{\mathrm{b}} \mathbf{1}=$ highest, $3=$ lowest.

Reference Materials. Our reference material is a low carbon, austenitic stainless steel. One candidate is AISI 316L, a stainless steel with 2 to $3 \%$ molybdenum for resistance to pitting corrosion. We - will further specify a premium grade with an extra low carbon content of less than $0.02 \% \mathrm{C}$ if experimental results and analysis indicate that chromium carbide precipitation (sensitization) will occur during welding. A nuclear grade such as 316LN may be specified to help prevent long-term low temperature sensitization.

A second candidate material, AISI 321 stainless steel, is a general-purpose, austenitic stainless steel with a titanium addition for stabilization of the carbon. Stabilization prevents the formation of chromium-carbides (sensitization) during welding, as well as over long periods of time at low temperatures $\left(100\right.$ to $\left.300^{\circ} \mathrm{C}\right)$.

A third candidate is AISI 304L stainless steel, a low carbon, general-purpose austenitic stainless steel. We will further specify a premium grade with an extra low carbon content of less than $0.02 \% \mathrm{C}$ if experimental results and analysis indicate that chromium carbide precipitation (sensitization) will occur during welding. (Type 304 is used for space frames to stabilize spent fuel inside the canisters.)

Incoloy 825 is a fourth candidate. It is a nickeliron-chromium-molybdenum-copper austenitic alloy designed for use in extremely corrosive environments. This alloy is stabilized with titanium to resist intergranular corrosion and intergranular stress-corrosion cracking. The nickel content makes it very resistant to transgranular stresscorrosion cracking. The molybdenum and copper give this alloy resistance to pitting and crevice corrosion. The high chromium content gives it resistance to various types of oxidizing environments.

Reference for Borehole Liners. AISI 1020 steel is a low carbon, general-purpose steel, for borehole 
liners, appropriate for a 50-year retrieval period. AISI 1020 steel has satisfactory properties for use as hole liners and is very attractive from a cost standpoint.

The remaining materials were not selected for the following reasons:

- ASTM A537B steel: low corrosion resistance for overpacks and canisters and more expensive compared to AISI 1020 steel for borehole liners.

- AISI 409 stainless steel: relative weldability problems.

- $26 \mathrm{Cr}-1$ Mo steel: relative weldability problems.

- AISI 317L stainless steel: more expensive compared to AISI 316L stainless steel, with limited improvement in corrosion resistance.

- Nitronic 33: more expensive than AISI 304L stainless steel, with minor improvement in properties.

- JS 700: more expensive than to AISI 304L stainless steel and weldability problems.

- Ferralium 255: unacceptable nil-ductility temperature and more expensive than AISI $304 \mathrm{~L}$ stainless steel.

- Inconel 625: more expensive than Incoloy 825. $800^{\circ} \mathrm{C}$

Ti Code 2: expensive, low yield strength at

- Ti Code 12: expensive, relative weldability problems, low fracture toughness.

- $\mathrm{Zr}$ 702: expensive, relative weldability problems, low fracture toughness.

- Cupronickel 70/30: potentially has low corrosion resistance in gamma-irradiated moist air and aerated water, and has low strength at room temperature and at $800^{\circ} \mathrm{C}$. However, this alloy is now (8/84) included in the list of candidate metals because of the need for an alternative alloy system to austenitic stainless steels.

\section{Thermal Analysis}

Many aspects of waste package design and testing depend in part on the temperature environment to which the emplaced packages will be exposed. In the design and analysis process, information produced by thermal analysis was used for the following purposes:

- To demonstrate that designs will not exceed maximum temperature criteria for the various waste forms: $623 \mathrm{~K}\left(350^{\circ} \mathrm{C}\right)$ for $S F, 673 \mathrm{~K}$ $\left(400^{\circ} \mathrm{C}\right)$ for $\mathrm{CHLW}$ glass, and $773 \mathrm{~K}\left(500^{\circ} \mathrm{C}\right)$ for WV/DHLW glass.
- To provide the calculated temperature environment for transportation, handling, storage, and retrieval analyses.

- To calculate approximate time periods of steam/water contact with waste package.

- To predict temperatures (and therefore effects on materials) that would result from canister fire tests.

\section{Model}

TACO2D (Burns, 1982), a two-dimensional implicit finite-element code, was used to analyze waste package conceptual designs. TACO2D requires temperature-dependent material properties data, a mesh representing the physical geometry, and the time-dependent thermal loading of the waste form as input. Code output consists of temperature histories at all nodes of the mesh. Using TACO, both the vertical and horizontal emplacement schemes have been analyzed.

TACO3D (Mason and Burns, 1981), a threedimensional implicit finite-element code, was also used to analyze waste-package conceptual designs. This code requires input similar to and gives output similar to TACO2D. TACO3D was used to calculate temperature histories in the host rock and to analyze the vertical emplacement configuration where three-dimensional modeling gave improved accuracy over two-dimensional modeling.

Assumptions and Approximations. Aside from the modeling approximations, a number of other assumptions and approximations have been made that are though: to have a minimal effect on the accuracy of the results. However, ventilation in the drifts was not assumed and could have a significant effect in reducing waste package temperatures during the preclosure period for vertical emplacement. The general assumptions are as follows, but minor variations from these were made in certain calculations:

- The thermal properties of dry air or helium were used for gaps inside the outermost containment barrier. The current design plans are for the canisters to be backfilled with argon. Since argon has a lower conductivity than air or helium, its use would raise temperatures. However, heat transfer is mainly by thermal radiation, which would minimize the effect of the fill gas.

- The thermal properties of $100 \%$ humid air were used for gaps between the outermost containment barrier and the surrounding tuff up to a temperature of $373 \mathrm{~K}\left(100^{\circ} \mathrm{C}\right)$, at which point the properties of $100 \%$ steam were used. 
- Heats of vaporization and recondensation, and fluid transport were not included in the analyses; however, changes in the thermal conductivity and specific heat due to fluid phase changes in the rock were considered. Fluid transport with vapor evaporation and condensation could lower the waste package temperatures given in this report.

- No initial geological temperature gradient in the tuff was used. An initial value of $302 \mathrm{~K}$ $\left(29^{\circ} \mathrm{C}\right)$ was used throughout the rock with the exception that a constant temperature boundary condition of $295 \mathrm{~K}\left(22^{\circ} \mathrm{C}\right)$ was used to represent the earth's surface $350 \mathrm{~m}$ above the repository. In addition, for the runs modeling vertically emplaced waste, a constant temperature boundary condition of $309 \mathrm{~K}\left(36^{\circ} \mathrm{C}\right)$ was used to represent a plane $350 \mathrm{~m}$ below the repository. Calculations showed that the effect on the waste package of not including the geothermal gradient in the problem was negligible.

- An initial temperature of $373 \mathrm{~K}\left(100^{\circ} \mathrm{C}\right)$ was assumed for each waste package at emplacement.

The boiling point of water was assumed to be $373 \mathrm{~K}\left(100^{\circ} \mathrm{C}\right)$. More recent estimates show the boiling point to be near $368 \mathrm{~K}\left(95^{\circ} \mathrm{C}\right)$ when altitude and impurity effects are considered. Using $95^{\circ} \mathrm{C}$ might increase the peak waste temperature slightly because of the greater heat capacity and conductivity of rock with water compared to vapor.

- Generally, all air gaps and spaces (including the access drift) include the effects of conduc- tion, natural convection and thermal radiation by means of a temperature-dependent equivalent thermal conductivity. This approach has been successfully used by others (Davis, 1979; Southwest Engineering Enterprise, 1979). In some analyses, thermal radiation was modeled (as radiation) separately from conduction and convection. Sensitivity analyses are needed to determine the exact effects of the modeling used.

- All materials (including the consolidated spent fuel rod assemblies) were assumed to be isotropic. Tables 9 and 10 show the material property values used for spent fuel and tuff respectively. The values in Table 9 reflect the fact that the consolidated spent fuel rod assemblies are not truly isotropic partly because of the air gaps between the rods (i.e., radial versus axial conductivity of assemblies). Axial heat generation variations were not included. The combination of higher axial conductivity and axial heat-generation variation is under evaluation.

\section{Vertical Emplacement}

In the vertical emplacement configuration, packages are emplaced in boreholes drilled vertically in the access drift floor (Scully, 1983).

Thermal calculations were made for wastes consisting of preconsolidated (boxed) spent fuel with a package configuration as shown in Figure 9. Each canister contained six assemblies of 10-year-old waste with a power of $3.3 \mathrm{~kW}$ at time of emplacement.

Two cases (see cases 24 and 25, Table 11) were calculated with pertinent dimensions given in

Table 9. Equivalent spent fuel material properties used for thermal analyses (Westinghouse, 1983, pp. 337, 340).

\begin{tabular}{lcc}
\hline Density & & $2000\left(\mathrm{~kg} / \mathrm{m}^{3}\right)$ \\
Specific heat & & $2640(\mathrm{~J} / \mathrm{kgK})$ \\
Thermal conductivity & $\mathrm{T}(\mathrm{K})$ & \\
& $273 / \mathrm{W} / \mathrm{mK})$ \\
& 323 & 0.060 \\
& 373 & 0.070 \\
& 423 & 0.093 \\
& 473 & 0.135 \\
& 523 & 0.190 \\
& 573 & 0.263 \\
623 & 0.355 \\
& 673 & 0.460 \\
& & 0.590 \\
\hline
\end{tabular}


Table 10. Tuff material properties used for thermal analyses.

\begin{tabular}{lcc}
\hline Density & & $2244\left(\mathrm{~kg} / \mathrm{m}^{3}\right)$ \\
Specific heat & $\mathrm{T}(\mathrm{K})$ & $\mathrm{C}_{\mathrm{p}}(\mathrm{kg} / \mathrm{kK})$ \\
& 273 & 97.4 \\
& 372 & 971.4 \\
& 373 & 689.0 \\
& 673 & 689.0 \\
& & $\mathrm{k}(\mathrm{W} / \mathrm{mK})$ \\
& $\mathrm{T}(\mathrm{K})$ & 1.8 \\
& 273 & 1.8 \\
& 372 & 1.6 \\
& 373 & 1.6 \\
\hline
\end{tabular}

Table 11. The difference between the two cases is in drift and package spacing.

The calculations were made in two stages. The first stage was a calculation to determine the borehole wall temperature history. A threedimensional model using TACO3D was used. This model consisted of a spent-fuel-like heat source inside the borehole surrounded by tuff with appropriate symmetry planes between boreholes and between drifts. A linear analysis was made using dry tuff thermal properties and an initial tuff temperature of $25^{\circ} \mathrm{C}$. The second stage modeled the waste package inside the borehole and used the temperature history of stage 1 as a boundary condition at the borehole wall. A twodimensional, variable-property, infinite-cylinder model using TACO2D was used to calculate the temperature history of the waste package.

Figure 13 shows temperature histories calculated in case 25 for peak fuel, canister outer diameter, borehole wall and host rock at one meter from the borehole wall. Peak fuel temperatures of $299^{\circ} \mathrm{C}$ and $322^{\circ} \mathrm{C}$ for cases 24 and 25 occurred four years after emplacement and are below the $350^{\circ} \mathrm{C}$ allowable limit. The higher (but acceptable) temperature in case 25 resulted from reducing the package pitch (spacing) from $8 \mathrm{~m}$ (ref) to $5 \mathrm{~m}$ and increasing the drift pitch from $30.48 \mathrm{~m}(100 \mathrm{ft})$ to $46.86 \mathrm{~m}(154 \mathrm{ft})$. This reduces the number of drifts, which lowers mining costs.

\section{Horizontal Emplacement}

In the horizontal emplacement configuration, horizontal boreholes of lengths of $180 \mathrm{~m}$ would be bored at predetermined spacings perpendicular to the access drifts. A two-dimensional model oriented perpendicularly to the axis of a borehole of infinite length was used to model this emplacement mode. This is a reasonable approximation since the ratio of borehole length to borehole diameter is about 200 . The accuracy of results produced by this model is better for packages emplaced near the center of the borehole where end effects do not play a significant role until very late times. Temperatures near the ends of the boreholes are cooler than at the modeled central region.

In the horizontal configuration, packages are placed end to end in the boreholcs. However, even when canisters are touching, space does exist in the borehole volume that cloes not contain waste (e.g., pintles, partially filled canisters). To account for this in the two-dimensional infinite cylinder model, a combination of two computer runs was used. To model the waste package, the first run assumed a cylinder of fully loaded waste with no allowance for gaps and partially filled canisters. To model the borehole and rock, the second run allowed for gaps by means of a lower loading density, with the total heat load per package spread evenly over the volume of the borehole. The temperature drop across the waste form and canister from the first run was then superimposed onto the temperature history of the borehole wall from the second run. This superposition tech nique is necessary to approach three-dimensional accuracy using the more efficient twodimensional code. 
Table 11. Significant input parameters and output results for the 10-year-old waste thermal analyses.

\begin{tabular}{|c|c|c|c|c|c|}
\hline \multirow[b]{2}{*}{ Case number } & \multicolumn{3}{|c|}{ WV/DHLW } & \multirow[b]{2}{*}{ : } & \multirow{2}{*}{$\frac{\text { CHLW }}{4}$} \\
\hline & 1 & 2 & 3 & & \\
\hline Directory number & D50H0.388 & D69H0.56A & D69H0.68A & : & $\mathrm{C} 50 \mathrm{H} 2.21 \mathrm{~A}$ \\
\hline Emplacement mode & $H^{\prime \prime}$ & $\mathrm{H}^{3}$ & $\mathrm{H}^{\star}$ & : & $H^{2}$ \\
\hline Areal power density (kW/acre) & 41.5 & 56.8 & 57.3 & : & 44.9 \\
\hline Package power at burial (W) & 380 & 556 & 680 & $:$ & 2210 \\
\hline Canister diam $(\mathrm{cm})$, & 61 & 81 & b1 & : & 32.4 \\
\hline material & $\mathrm{SST}^{*}$ & $\mathrm{SST}^{*}$ & SST & : & SST \\
\hline Overpack diam (cm), & 66 & 86.1 & B6.1 & $:$ & 37.5 \\
\hline material & SST & SST' & SST & $:$ & SST \\
\hline Borehole liner diam (cm) & 72.4 & 92.4 & 92,4 & : & 43.8 \\
\hline material & $\operatorname{Cs}^{d}$ & $\mathrm{CS}^{\prime \prime}$ & $\mathrm{CS}^{d}$ & $:$ & $\mathrm{CS}^{d}$ \\
\hline $\begin{array}{l}\text { Packing outer diam (cm), } \\
\text { material }\end{array}$ & - & - & - & $\begin{array}{l}: \\
:\end{array}$ & - \\
\hline Borehole diam (cm) & 81.3 & 101.6 & 101.6 & $:$ & 54.0 \\
\hline Borehole pitch (m) & 8.8 & 9.4 & 11.5 & : & 44.0 \\
\hline Package pitch (m) & 3.5 & 3.5 & 3.5 & : & 4.0 \\
\hline Drift pitch (m) & - & - & - & : & - \\
\hline $\begin{array}{l}\text { Number of internal fins, } \\
\text { material }\end{array}$ & - & - & - & : & - \\
\hline Model & $1 C^{3}$ & $\mathrm{IC}^{\mathrm{k}}$ & $I C^{R}$ & $\vdots$ & $I^{B}$ \\
\hline Temperature limit $\left({ }^{\circ} \mathrm{C}\right)$ & 500 & 500 & 500 & : & 400 \\
\hline Peak waste temp $\left({ }^{\circ} \mathrm{C}\right)$ & 121 & 154 & 165 & : & 333 \\
\hline lime $(y r)$ & 17.5 & 30 & 17.5 & ; & 2.0 \\
\hline Waste temp at 300 yrs $\left({ }^{\circ} \mathrm{C}\right)$ ! & 62 & 78 & 73 & : & 101 \\
\hline Waste temp at $1000 \mathrm{yrs}\left({ }^{\circ} \mathrm{C}\right)$ & 44 & 54 & 30 & : & 59 \\
\hline J'eak borchole temp $\left({ }^{\circ} \mathrm{C}\right)$ & 101 & 136 & 135 & : & 206 \\
\hline time (yr) & 35 & 35 & 30 & : & 4.2 \\
\hline $\begin{array}{l}\text { Peak teniperature }\left({ }^{\circ} \mathrm{C}\right)-1 \mathrm{~m} \\
\text { from borehole surface }\end{array}$ & 96 & 129 & 127 & $:$ & 145 \\
\hline
\end{tabular}

Thermal calculations were made for preconsolidated (boxed) spent fuel from a pressurized water reactor. The design consisted of three boxes of fuel (six assemblies) in canisters emplaced end-to. end in long horizontal boreholes at a depth of $400 \mathrm{~m}$ with $52-\mathrm{m}$ spacing between boreholes, resulting in an areal power density of $40.6 \mathrm{~kW} / \mathrm{acre}$. The canister had a $68-\mathrm{cm}$ outer diameter with a 1-cm-wall thickness of 304-type stainless steel and a length of $4.5 \mathrm{~m}$. Figure 14 shows the package. The canisters were placed: n $84-\mathrm{cm}$-diameter horizontal borehole lined with a 76-cm-insidediameter carbon steel liner that has a 1-cm-wall thickness. Saturated air is assumed in the gap between the borehole wall and the liner. Dry air is assumed between the liner and canister, and helium is contained inside the canister.
The PWR spent fuel was 10 years out of the reactor core with a decay power of $1.1 \mathrm{~kW}$ per consolidated box, which for three voxes resulted in a power of $3.3 \mathrm{~kW}$ per canister. This power represents the highest power expected for a PWR canister. The boxes were $21.42 \mathrm{~cm}$ square surrounded by a $1-\mathrm{cm}$-thick carbon steel space frame. The fuel length was $3.89 \mathrm{~m}$.

Calculations from the time of emplacement up to 1000 years were made and are shown in Figure 15. Table 11, case 22, shows the key dimensions and results for this case. Table 11 also contains a summary of significant input and output parameters for the thermal analyses completed to date. Also, see Figure 16 for results of WVIDHLW emplaced horizontally. 
Table 11. (Continued)

\begin{tabular}{|c|c|c|c|c|c|}
\hline \multirow[b]{2}{*}{ Case number } & \multicolumn{5}{|c|}{ PWR } \\
\hline & 13 & 14 & 15 & 16 & 17 \\
\hline Directory number & $\mathrm{P} 56 \mathrm{H} 3.3 \mathrm{~A}$ & P56H3.3B & $\mathrm{P} 56 \mathrm{H} 3.3 \mathrm{C}$ & P57H3.3C: & P57H3.3B \\
\hline Emplacement mode & $\mathrm{H}^{\prime \prime}$ & $\mathbf{H}^{\mathbf{4}}$ & $\mathrm{H}^{\prime \prime}$ & $\mathrm{H}^{*}$ & $\mathrm{H}^{*}$ \\
\hline Areal power density (kW/acre) & 43.2 & 43.2 & 43.2 & 43.6 & 43.6 \\
\hline Package power at burial (W) & 3300 & 3300 & 3300 & 3300 & 3300 \\
\hline Canister diam (cm), & 45.0 & 45.0 & 45.0 & 50.0 & 50.0 \\
\hline material & SST & SST & SST & SST & SST \\
\hline $\begin{array}{l}\text { Overpack diam }(\mathrm{cm}) \text {, } \\
\text { material }\end{array}$ & - & - & - & - & - \\
\hline Borehole liner diam (cm) & 51.4 & 86.4 & 86.4 & 62.2 & 62.2 \\
\hline material & $\mathbf{C S}^{d}$ & $\mathrm{CS}^{\mathrm{d}}$ & $\mathbf{C S}^{\mathrm{d}}$ & $\mathrm{CS}^{\mathrm{d}}$ & $\mathrm{CS}^{\mathrm{d}}$ \\
\hline Packing outer diam (cm), & - & 80.1 & $B 0.1$ & - & - \\
\hline material & & CCT1 $^{\mathrm{E}}$ & $\mathrm{CCT1}^{\mathrm{e}}$ & & \\
\hline Borehole diem (cm) & 61.0 & 96.5 & 96.5 & 69.0 & 69.0 \\
\hline Borehole pitch (m) & 48.9 & 48.9 & 48.9 & 52.0 & $\mathbf{5 2 . 0}$ \\
\hline Package pitch (m) & 4.8 & 4.8 & 4.8 & 4.5 & 4.5 \\
\hline Drift pitch (m) & - & - & - & - & - \\
\hline Number of internal fins, & 6 & 6 & - & 6 & 12 \\
\hline material & SST & SST & - & $\mathrm{CS}^{\mathrm{d}}$ & $\mathrm{CS}^{\mathrm{d}}$ \\
\hline Model & IC $^{\mathbf{s}}$ & $1 \mathrm{C}^{\mathrm{B}}$ & $1 C^{B}$ & IC' & $1 C^{8}$ \\
\hline Temperature limit $\left({ }^{\circ} \mathrm{C}\right)$ & 350 & 350 & 350 & 350 & 350 \\
\hline Peak waste temp $\left({ }^{\circ} \mathrm{C}\right)$, & 312 & 379 & 449 & 343 & 327 \\
\hline time $(y x)$ & 2.5 & 2.0 & 2.5 & 3.0 & 3.0 \\
\hline Waste temp at $300 \mathrm{yrg}\left({ }^{\circ} \mathrm{C}\right)$ & 148 & 155 & 185 & 153 & 144 \\
\hline Waste temp at 1000 yrs $\left({ }^{\circ} \mathrm{C}\right)$. & 109 & 111 & 129 & 109 & 105 \\
\hline Peak borehole temp $\left({ }^{\circ} \mathrm{C}\right)$, & 237 & 215 & 223 & 252 & 246 \\
\hline time (yr) & 4.0 & 7.0 & 7.5 & 4.0 & 3.5 \\
\hline \multicolumn{6}{|l|}{ Peak temperature $\left({ }^{\circ} \mathrm{C}\right) \sim 1 \mathrm{~m}$} \\
\hline from borehole surface & 170 & 158 & 167 & 175 & 175 \\
\hline
\end{tabular}

\section{Effecta of Packing on Waste Temperature}

Special attention should be paid to completed analyses that gave the thermal effects of introducing packing into the design. The analyses (cases 13 and 14) incorporated a 15-cm annilar thickness of compressed crushed tuff packing around horizontally emplaced canisters containing PWR spent fuel (thermal conductivity, $k=0.97 \mathrm{~W} / \mathrm{mK}$ ). Note that after this analysis was completed, a value for compressed tuff conductivity was measured to be $0.65 \mathrm{~W} / \mathrm{mK}$. The results showed that with no packing the peak fuel temperature was about $613 \mathrm{~K}$ $\left(340^{\circ} \mathrm{C}\right)$ but when packing was included the peak fuel temperature was $681 \mathrm{~K}\left(408^{\circ} \mathrm{C}\right)$, which is above the design limit of $623 \mathrm{~K}\left(350^{\circ} \mathrm{C}\right)$ for spent fuel.

The use of $15 \mathrm{~cm}$ of crushed, compressed tuff packing necessitated redesign of the reference spent fuel canister to avoid raising the peak fuel temperature above allowable limits. Analysis showed that a canister containing no more than four PWR spent fuel rod assemblies would be needed to satisfy the temperature limit (see Table 11, case 21). The thermal penalty of incorporating packing would be $50 \%$ mcre packages with the additional economic effects of larger boreholes, additional costs for packing assemblies, as well as the addi.ional handling required.

\section{Fire Test Thermal Analysis}

A computer simulation of a fire test was performed using TACO2D on a 57-cm-diameter canister containing BWR spent fuel with $3.42 \mathrm{~kW}$ of thermal power. An $800^{\circ} \mathrm{C}$ constant-temperature boundary condition was applied to the outer surface of the canister for a period of $30 \mathrm{~min}$ to simulate the fire test required in 10 CFR 71 (NRC, 1982). The canister was assumed to be standing vertically in a hot cell. 
Table 11. (Continued)

\begin{tabular}{|c|c|c|c|c|c|c|}
\hline \multirow[b]{2}{*}{ Case number } & \multicolumn{6}{|c|}{ PWR } \\
\hline & 20 & 21 & 22 & 23 & 24 & 25 \\
\hline Directory number & P57H3.3A & P57H2.2A & P5OH3.3A & $\mathrm{P} 50 \mathrm{H1} 1.65 \mathrm{~A}$ & P50V3.3A & P57V3.3A \\
\hline Emplacement Mode & $\mathrm{H}^{*}$ & $\mathrm{H}^{*}$ & $\mathbf{H}^{*}$ & $H^{*}$ & $\mathbf{V}^{\mathbf{b}}$ & $\mathbf{V}^{b}$ \\
\hline Areal power density (kW/acre) & 43.6 & 42.0 & 40.6 & 40.6 & 46.9 & 48,4 \\
\hline Package power at burial (W) & 3300 & $2200^{\prime}$ & 3300 & 1650 & 3300 & $330 ;$ \\
\hline $\begin{array}{l}\text { Canister diam (cm), } \\
\text { material }\end{array}$ & $\begin{array}{l}50.0 \\
S S T\end{array}$ & $\begin{array}{l}40.0 \\
S 5 T^{c}\end{array}$ & $\begin{array}{l}68.0 \\
S S T^{c}\end{array}$ & $\begin{array}{l}68.0 \\
S S T\end{array}$ & $\begin{array}{l}70.0 \\
S S T\end{array}$ & $\begin{array}{l}70.0 \\
S S T^{c}\end{array}$ \\
\hline $\begin{array}{l}\text { Overpack diam }(\mathrm{cm}) \\
\text { material }\end{array}$ & - & - & - & - & - & - \\
\hline $\begin{array}{l}\text { Borehole liner diam }(\mathrm{cm}) \\
\text { material }\end{array}$ & $\begin{array}{l}85.0 \\
\mathrm{CS}^{d}\end{array}$ & $\begin{array}{l}76.4 \\
C S^{d}\end{array}$ & $\mathrm{CS}^{\mathrm{d}}$ & $\begin{array}{l}76.0 \\
C S^{d}\end{array}$ & - & - \\
\hline $\begin{array}{l}\text { Packing outer diam (cm), } \\
\text { material }\end{array}$ & $\begin{array}{r}82.4 \\
\text { CCT1 }^{e}\end{array}$ & $\begin{array}{r}72.5 \\
\text { CCT2 }^{\prime}\end{array}$ & - & - & - & - \\
\hline Borehole diam (cm) & 92.8 & B1.3 & 84.0 & 84.0 & 76.2 & 76.2 \\
\hline Borehole pitch (m) & 52,0 & 34.7 & 52.0 & $52 . ?$ & - & - \\
\hline Package pitch (m) & 4.5 & 4.5 & 4.5 & 4.5 & 8.0 & 5.0 \\
\hline Drift pitch (m) & - & - & - & - & 30.48 & 46.86 \\
\hline $\begin{array}{l}\text { Number of , iternal fins, } \\
\text { material }\end{array}$ & $\begin{array}{c}24 \\
C S^{d}\end{array}$ & $\operatorname{cs}^{12}$ & - & - & - & - \\
\hline Model & $\mathrm{IC}^{\mathrm{B}}$ & $\mathrm{IC}^{8}$ & $\mathrm{IC}^{\mathbf{8}}$ & $\mathrm{IC}^{8}$ & $2 \mathrm{D} / 3 \mathrm{D}^{\mathrm{h}}$ & $2 \mathrm{D} / 3 \mathrm{D}^{\mathrm{h}}$ \\
\hline Temperature limit $\left({ }^{\circ} \mathrm{C}\right)$ & 350 & $\therefore 0$ & 350 & 350 & 350 & 350 \\
\hline Peak waste temp $\left({ }^{\circ} \mathrm{C}\right)$ & 374 & 326 & 335 & 295 & 299 & 322 \\
\hline time (yr) & 2.5 & 3.0 & 3.4 & 5.0 & 4 & 4 \\
\hline Waste temp at 300 yrs $\left({ }^{\circ} \mathrm{C}\right)$ & 156 & 152 & 161 & 147 & 165 & 171 \\
\hline Waste temp at 1000 yrs $\left({ }^{\circ} \mathrm{C}\right)$ & 112 & 108 & 112 & 105 & 127 & 130 \\
\hline $\begin{array}{l}\text { Peak borehole temp }\left({ }^{\circ} \mathrm{C}\right) \text {, } \\
\text { time (yr) }\end{array}$ & $\begin{array}{r}242 \\
7.0\end{array}$ & $\begin{array}{l}708 \\
1<.0\end{array}$ & $\begin{array}{r}244 \\
7.5\end{array}$ & $\begin{array}{l}244 \\
7.5\end{array}$ & $\begin{array}{r}200 \\
23\end{array}$ & $\begin{array}{r}236 \\
9\end{array}$ \\
\hline \multicolumn{7}{|l|}{ Peak temperature $\left({ }^{\circ} \mathrm{C}\right) \sim 1 \mathrm{~m}$} \\
\hline from borehole surface & 178 & 147 & 180 & 180 & 147 & 188 \\
\hline $\begin{array}{l}\text { H }=\text { Horizontal. } \\
\text { ' }=\text { Vertical. } \\
\text { ' SST = SAAL Stainless steel. } \\
{ }^{\text {C }} \text { CS = Carbon steel. }\end{array}$ & $\begin{array}{l}\text { ' CCT2 } \\
\text { B IC }=2 \\
\text { ' } 2 \mathrm{D} / 3 \mathrm{D} \\
{ }^{\prime} \text { Four fu }\end{array}$ & $\begin{array}{l}\text { mpressed cr } \\
\text { inite cylinde } \\
\text { infinite cyli } \\
\text { isemblies ins }\end{array}$ & $\begin{array}{l}\text { ed luíf }(k=0 \\
\text { inside bore } \\
\text { of six. }\end{array}$ & $\begin{array}{l}\text { W/mK, meast } \\
\text { 3D outside b }\end{array}$ & hole. & \\
\hline
\end{tabular}

Internal heat-conducting fins were modeled horizontally through the waste. In the reference design these fins are configured in a vertical direction because they also serve to contain the rods during consolidation operations. However, to model the problem in the less complex axisymmetric mode (i.e., two dimensional vs three dimensional), the fins were configured in the horizontal direction with the equivalent total volume of fin material (final designs w: il be modeled in 3D to improve accuracy). In each of the air spaces shown, thermal radiation, convection, and conduction were modeled by means of an equivalent thermal conductivity. An effective thermal con- ductivity was also used for the spent fuel as suggested in a report issued by Westinghouse (1983).

The initial temperatures through:out the canister (before applying the $80 \mathrm{C}^{\circ} \mathrm{C}$ boundary condition) were calculated using \& natural convection boundary condition of $5 \mathrm{~W} / \mathrm{m}^{2} \mathrm{~K}$ coupled with thermal radiation to a blackbody at $22^{\circ} \mathrm{C}$. The problem was run until a steady state ternperature in the canister was obtained. The temperatures of the package were then used as the initial temperatures for the simulated fire test with the new $800^{\circ} \mathrm{C}$ constant-temperature boundary condition applied. 


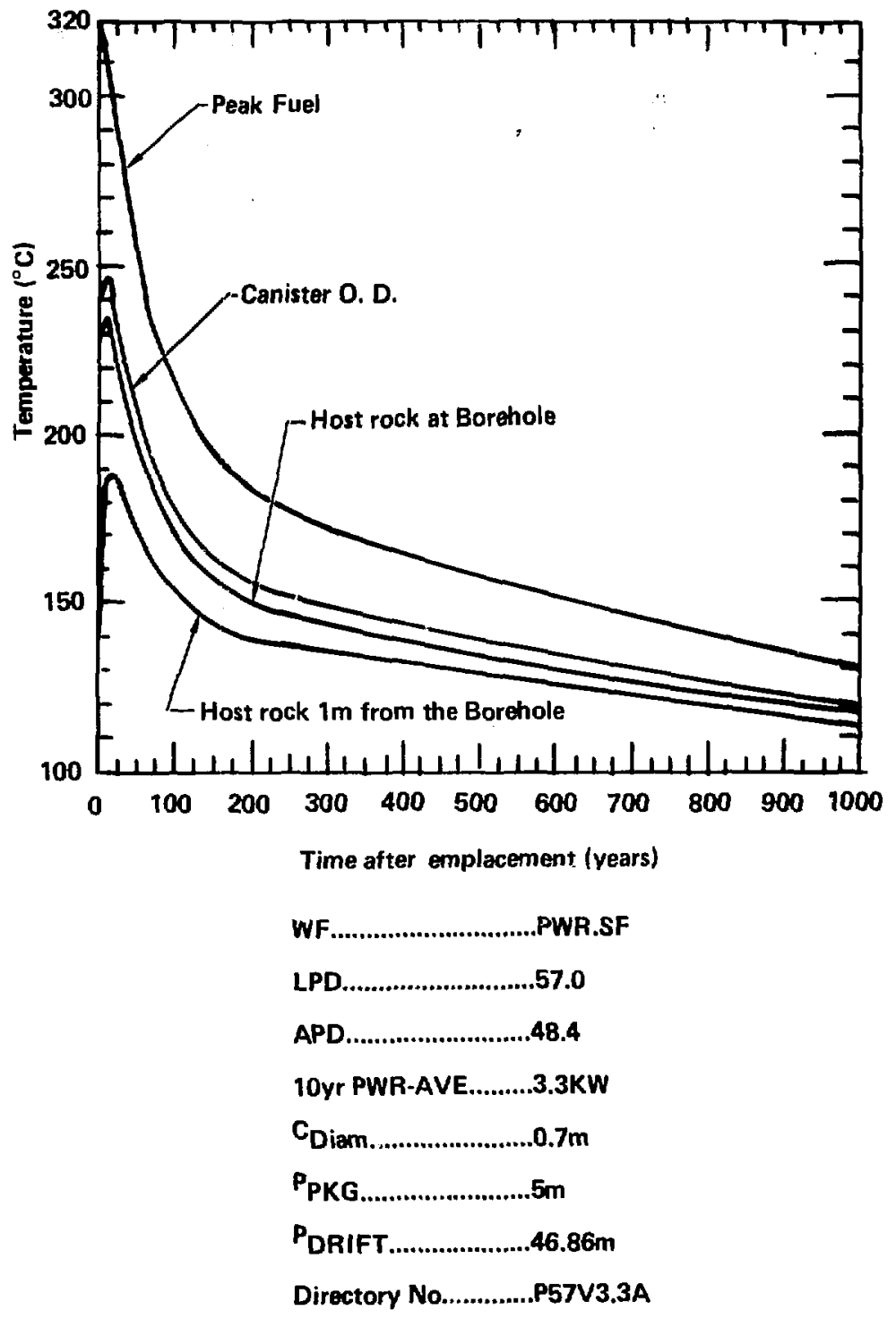

Figure 13. Temperature histories of waste package components and host rock for vertically emplaced spent fuel canister (case 25). 


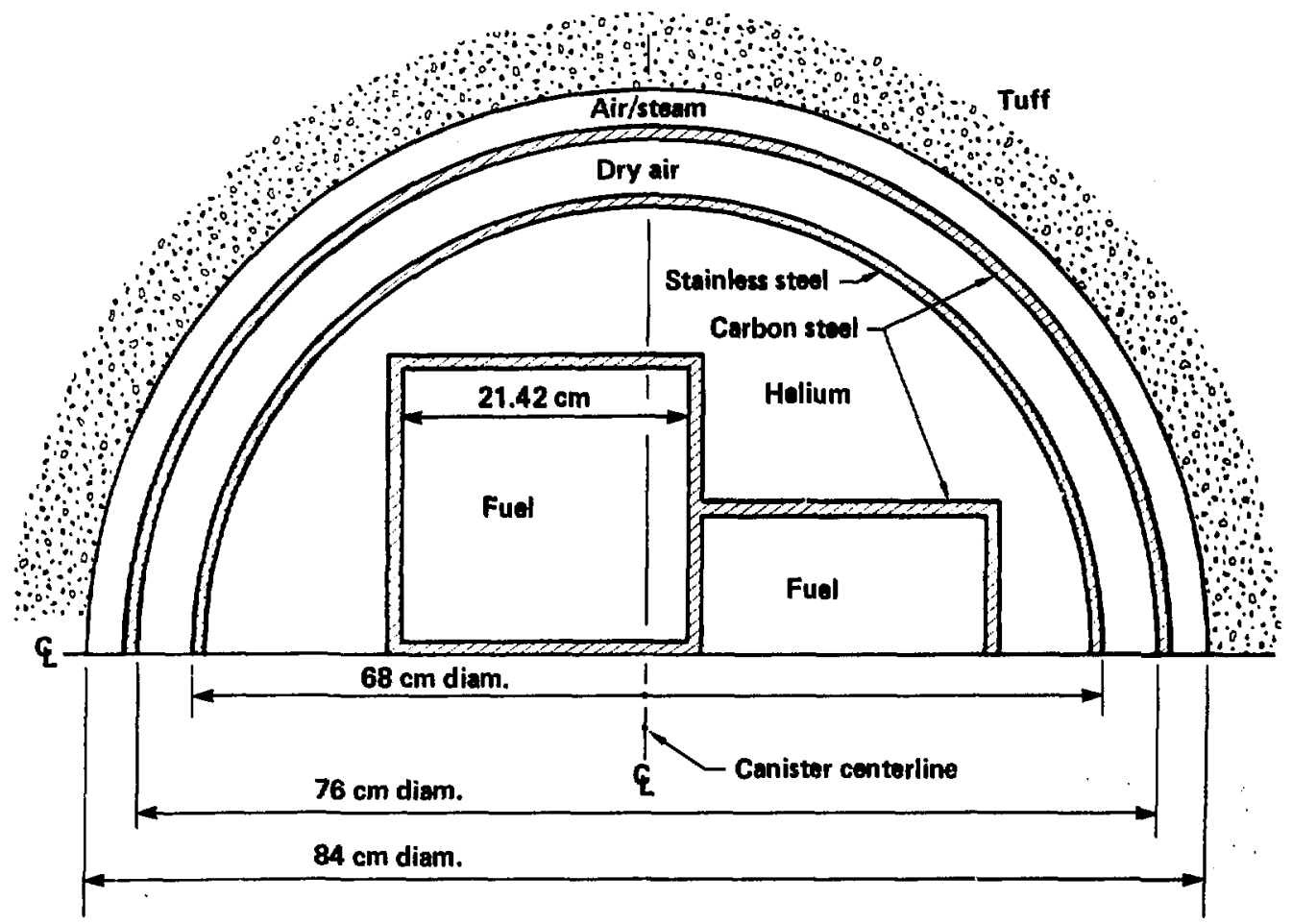

Figure 14. PWR spent fuel canister model: horizontal emplacement (case 22). A similar model was used for vertical emplacement without a liner.

Figure 17 shows the results of the TACO2D fire test simulation. The upper curve shows the temperature history of a typical node located in the air space directly above the fuel rods. The maximum temperature reached in 30 minutes was $788^{\circ} \mathrm{C}$. The middle curve represents tile top of a typical Zircaloy clad fuel rod. The top of the fuel rod reaches a temperature near $730^{\circ} \mathrm{C}$ in $30 \mathrm{~min}$. The lower curve represents the temperature history of the node at which the highest initial temperature occurred near the geometric center. As can be observed the geometric center of the fuel rod bundle was not affected in the relatively short time of the fire test. These results were used to calculate the pressure build-up in the canister (see "Structural Analysis" below).

\section{Conclusions}

- The reference and alternative conceptual designs do not exceed the temperature limits.
A significant thermal penalty results if a packing is used in the reference waste-package design. This effect is highly dependent on the material properties of the particular packing used. To stay within the temperature limits when packing is used, a lower heat output per package (implying more packages) has been specified in the current SF alternative design.

- The fire test simulation provided input temperatures to fire test structural analysis (see "Fire Test Structural Analysis" below).

\section{Recommendations for Future Work}

Before the design process is completed, a number of additional analyses will have to be done. The most significant of these will be a threedimensional modeling of canister and repository. Once the number of conceptual designs is reduced, three-dimensional analysis could be used 


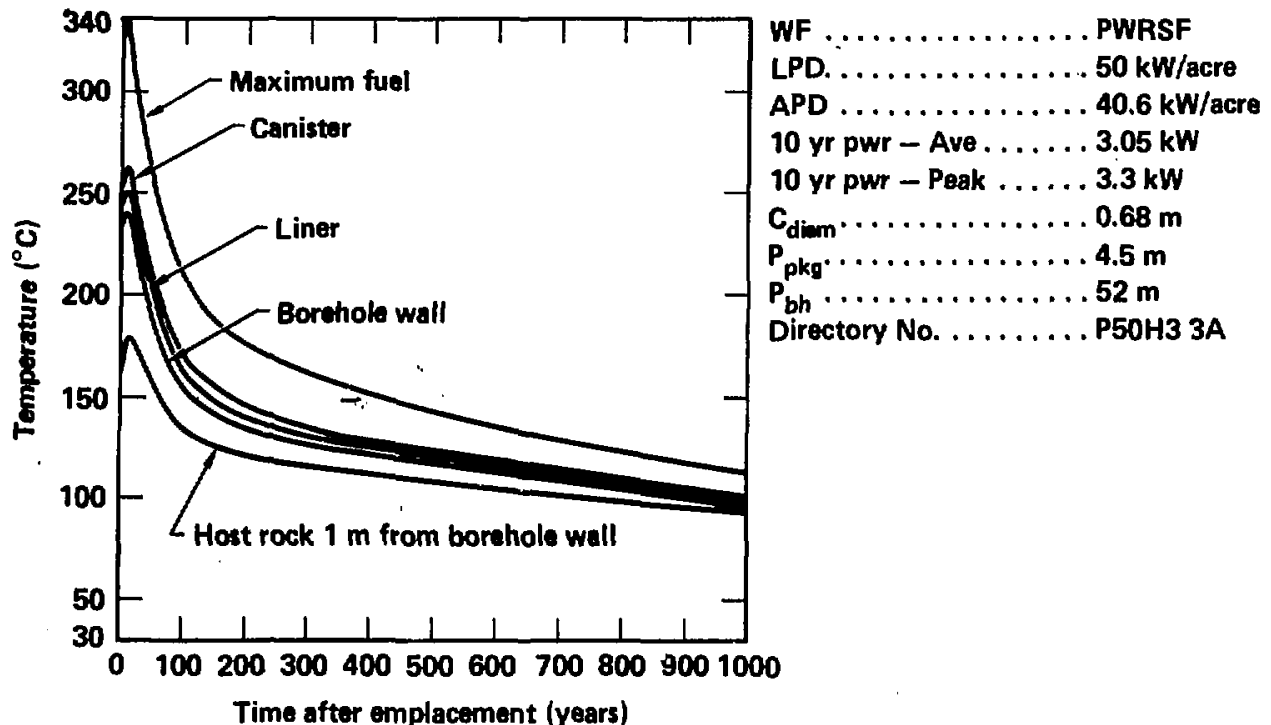

Figure 15. Temperature histories of waste package components and host rock for horizontally emplaced preconsolidated (boxed) PWR spent fuel (case 22).

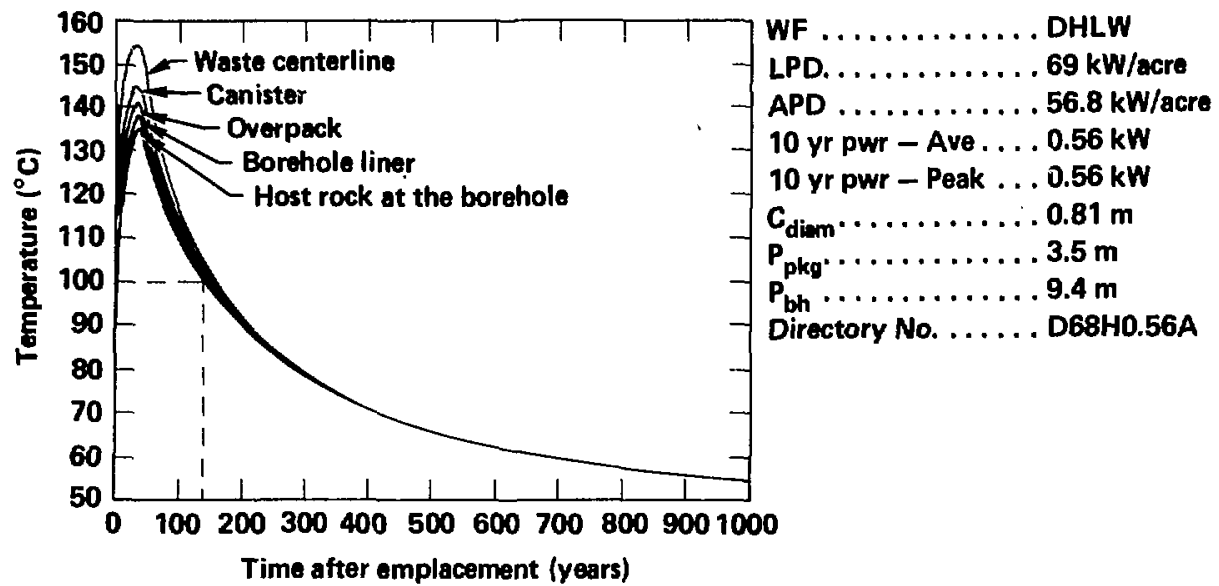

Figure 16. Temperature histories of waste package components and host rock for horizontally emplaced WV/DHLW caniater (case 2). 


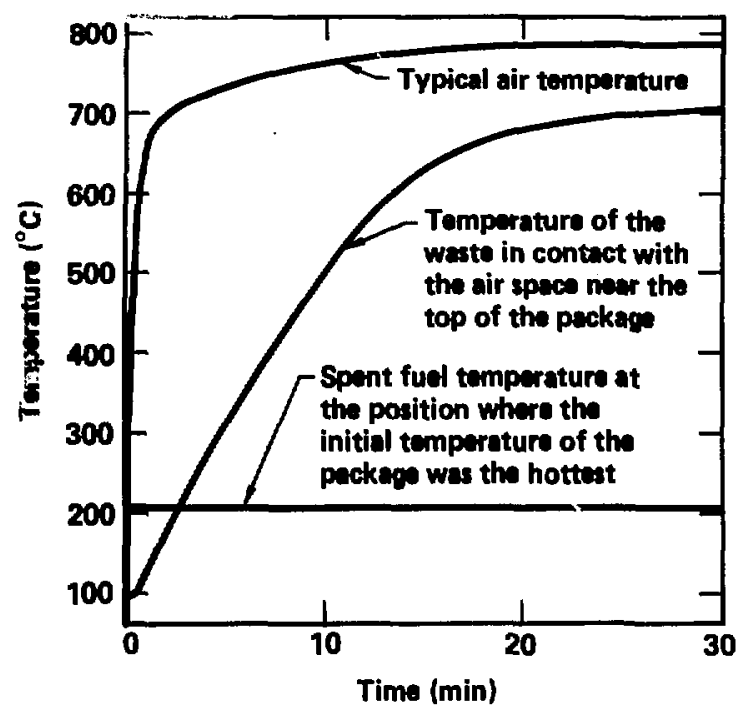

Figure 17. Results of simulated fire test analysis.

in a more economical way (both time and money) to provide more accurate final results.

In arditiun, some uncertainty is involved in the choice of n:aterial prosferties used in the calculations. This is partly tive result of uncertainties in the experimentally measured thif properties and partly the resilt of assumptions concerning air, water, and steam behavior near emplaced canisters. Paramete: atufies may be used to bound the effects of some of these material-property uncertàinties.

Other parameter siudies shuild be employed

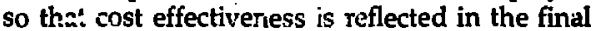
designs. Thermal anaiyses, including additional variation in areal power density, drift spacing, package spacing, package power, and canister diameter, are examples of poiential studies which, when completed, could inifiuence final designs.

Lastly, TACO2D and TACO3D should be reverified and revalidated using methods required by regulatory agencies (Silling, (099?). This will be necessary for computer codes used in design activities which provide input to the licersing of the repository.

\section{Nuclear Criticality Analysis}

\section{Background}

In 1983, Westinghouse conceptual designs for spent fuel waste packages were modified by LLNL for the unsaturated zone. The canisters contained fuel elements from six PWR or 18 BWR spent fuel assemblies consolidated (with no poison rods) in cylindrical space frames with triangular holes. * An analytical effort by Westinghouse Electric Corporation's Waste Technology Services Division in Pittsburgh, PA, was subcontracted by LLNL to determine if these designs conformed to the 10 CFR 60 criticality safety requirements (Weren et al., 1983). The analytical study was limited to a few scenarios and configurations over long time periods in order to identify any initial or rearranged configurations and any unlikely events which

\footnotetext{
- The final reference design is $70 \mathrm{~cm}$ in diameter and contains six PWR or 14 BWR assemblies in square holed space frames.
} 
might prevent conformance to $10 \mathrm{CFR} 60$ requirements. This section describes the scenarios considered and the results of the report.

When the analysis was undertaken, the reference spent fuel configuration specified that all spent fuel was to be consolidated; therefore, intact spent fuel assemblies were not analyzed. Because intact assemblies have pin spacings that provide room for water between pins, the effective neutron multiplication factor $k_{\text {eft }}$ of intact assemblies in a flooded condition can exceed 0.95 . To avoid this, neutron absorbing material is required in spent fuel waste packages containing intact assemblies.

\section{Description of Configurations Analyzed}

The reference fuel for the purpose of this numerical analysis is unirradiated fuel rods from six Westinghouse PWR standard $17 \times 17$ fuel assemblies containing $\mathrm{UO}_{2}$ fuel pellets enriched to 4.5wt\% U-235. The nominal configuration is closely packed spent fuel rods in a container placed in a borehole in a tuff geology. The 1584 fuel rods from the six fuel assemblies are maintained in a closely packed arrangement by a fabricated steel con- tainer, with no poison rods, shown in Figure $\mathbf{1 8 .}$ This container is placed inside a $304 \mathrm{~L}$ stainless steel canister which is inserted in a borehole. The canister and borehole are shown in Figure 19.

In postulating potential configurations for evaluation, it was useful to think in terms of three time frames: (1) emplacement and short times (decades) thereafter; (2) intermediate times after emplacement (hundreds of years); and (3) long times (up *. thousands of years) after emplacement. It is assumed that in each successive time period, fewer controls will remain on the geomctry of the waste form because of chemical degradation of materials and subsequent changes in geometry due to disintegration of structures.

It is expected that, in the short term, the nominal geometry at emplacement will exist. For this study we assumed that as time passes, first the container and the canister corrode and are lost, then the fuel rod cladding fails, releasing the fuel pellets, and finally the fuel pellets disintegrate to powder. At all times the potential for water intrusion must be considered. This scenario gives rise to 11 potential configurations, some dry and some flooded.

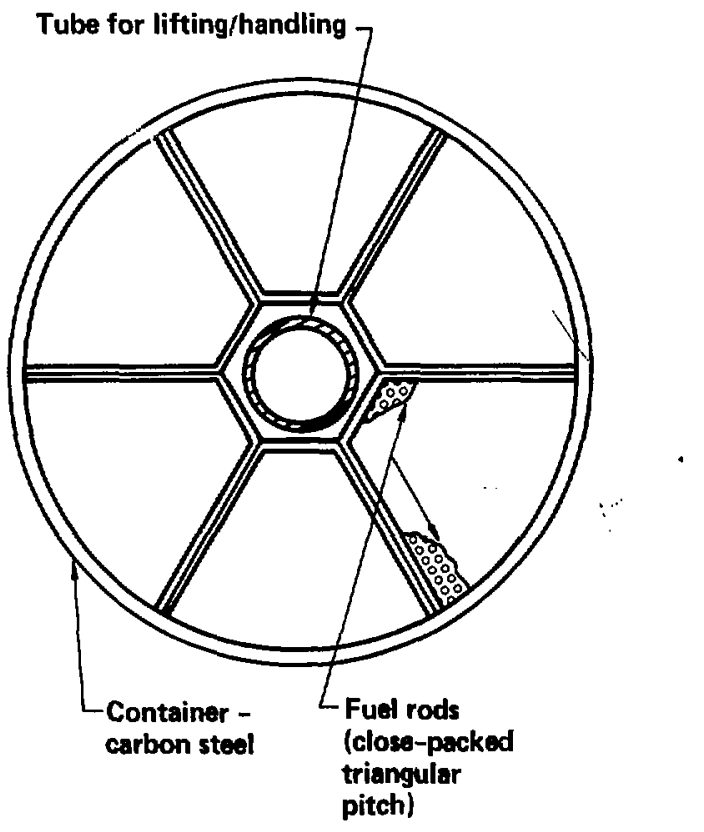

Figure 18. Spent fuel container cross section.

(Figures 8 to $\mathbf{1 0}$ show current reference designs.) 


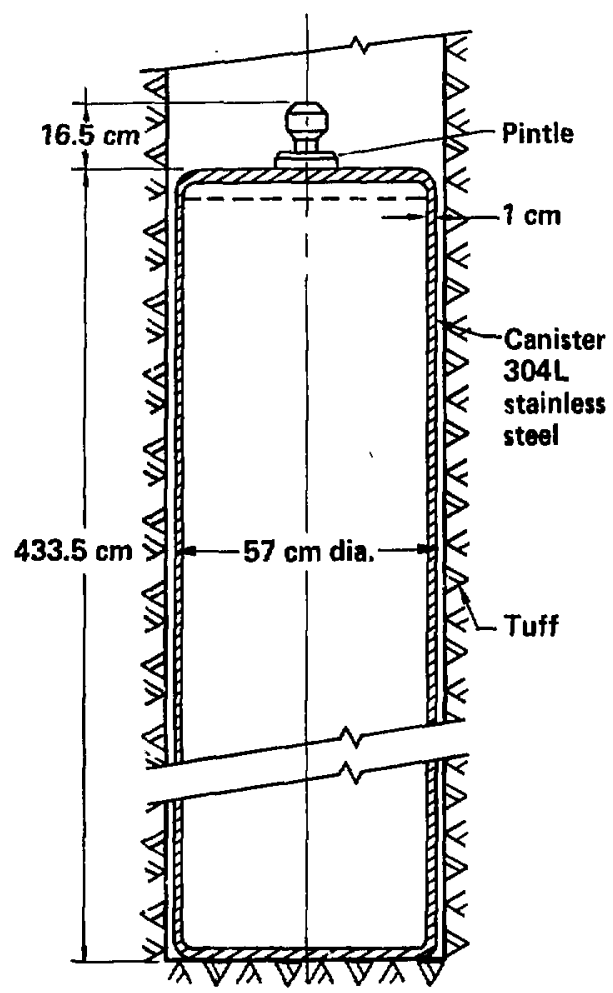

Figure 19. Spent fuel waste package used in this analysis. (Figures 8 to 10 show current reference designs.)

Current practice in safety analyses uses 0.95 as the upper limit for the effective neutron multiplication factor $\left(k_{\mathrm{eti}}\right)$. Many criticality studies have been performed for unmoderated (dry), fresh $\mathrm{UO}_{2}$ fuel. In particular, a safety assessment document (NVO, 1978) reports that no amount of fresh $\mathrm{UO}_{2}$ enriched up to $7-w t \%$ U-235 can be made critical without moderation and that an infinite array of dry closely packed PWR fuel assemblies would have a $k_{e i}$ less than 0.8 . Based on this and numerous other references not mentioned here, it was concluded that all of the dry potential configurations would be subcritical.

Some of the flooded configurations were expected to be critical using the initial assumptions. Various studies (Gore et al., 1980; McNair and Gore, 1980) conclude that demonstration of criti- cality safety in the geologic disposal of spent fuel will require taking credit for depletion (burn-up) of the fissile inventory during irradiation. Those conclusions are confirmed by the results of this study (for disposal of spent fuel with no neutron absorbing poison rods).

\section{Potential Configurations}

Eleven potential configurations are identificd and summarized in Table 12. Each of these configurations was described in Weren et al. (1983). Configurations $1,2,6$, and 10 were evaluated in this study. Figure 20 illustrates configuration 6 .

The extreme assumptions of Configurations 9 and 11 - that all of the cladding is gone and that only fuel powder (Configuration 9) or an optimal mixture of fuel powder and water (Configuration 11) remains - are apparently unrealistic since it is believed that the cladding will not be leached away faster than the fuel. A more realistic configuration (number 10) is thought to be some mixture of cladding, fuel powder and water in the bottom of a borehole with the remaining cladding and more water above as shown in Figure 21. To determine the proportions in the fuel/clad/water mixture, it was assumed that all of the fuel was in powdered form in a cylinder the diameter of the borehole; the height of the cylinder was determined so as to accommodate all of the fuel plus the volume of cladding that would normally be in. cluded in that height. The water volume fraction was assumed to be that of the void fraction in dry powder (i.e., water would fill the void spaces in the powder as opposed to assuming optimum moderation). The remaining clad and water were assumed to be present in a layer above the fuel/ clad/water mixture. Configuration 9 (dry) will be subcritical. According to Heaberlin and Selby (1978), with no cladding, a cylinder diameter of ten inches or less of optimally moderated 3.5wt\%-enriched $\mathrm{UO}_{2}$ would be required to achieve an acceptable reactivity. Thus Config:aration 11 was expected to be critical assuming fresh fuel. Configuration 10 was found to be critical as anticipated, and an assessment of the burn-up effects was made.

\section{Accounting for Fissile Inventory Depletion}

The assumption of fresh fuel for-spent-fuelstorage-criticality studies has been shown to je very conservative. Although this approach is the simplest and is typically of use where acceptable results are obtained, recently licensed designs of spent fuel storage racks have been based on taking credit for the fissile inventory depletion that 
Table 12. Potential configurations.

\begin{tabular}{|c|c|}
\hline $\begin{array}{l}\text { Configuration } \\
\text { number }\end{array}$ & Description \\
\hline $1^{n}$ & Nominal configuration - dry \\
\hline $\mathbf{2}^{*}$ & Nominal configuration - flooded \\
\hline 3 & Nominal configuration - partial flooding \\
\hline 4 & Structure gone - rods uniformly spaced - dry \\
\hline 5 & Structure gone - rods uniformly spaced - flooded \\
\hline $6^{4}$ & $\begin{array}{l}\text { Container partially gone - optimal rearrangement of rods - } \\
\text { flooded }\end{array}$ \\
\hline 7 & Structure and clad gone - pile of pellets - dry \\
\hline 8 & Structu: and clad gone - pile of pellets - flooded \\
\hline 9 & Structure and clad gone - pellets disintegrated to powder - dry \\
\hline $10^{4}$ & Clad and disintegrated pellets (powder) optimally mixed - flooded \\
\hline 11 & $\begin{array}{l}\text { Structure and clad gone - pellets disintegrated to powder - } \\
\text { flooded }\end{array}$ \\
\hline
\end{tabular}

- Configurations analyzed.

${ }^{\mathrm{b}}$ Structure is defined as the container and canister.

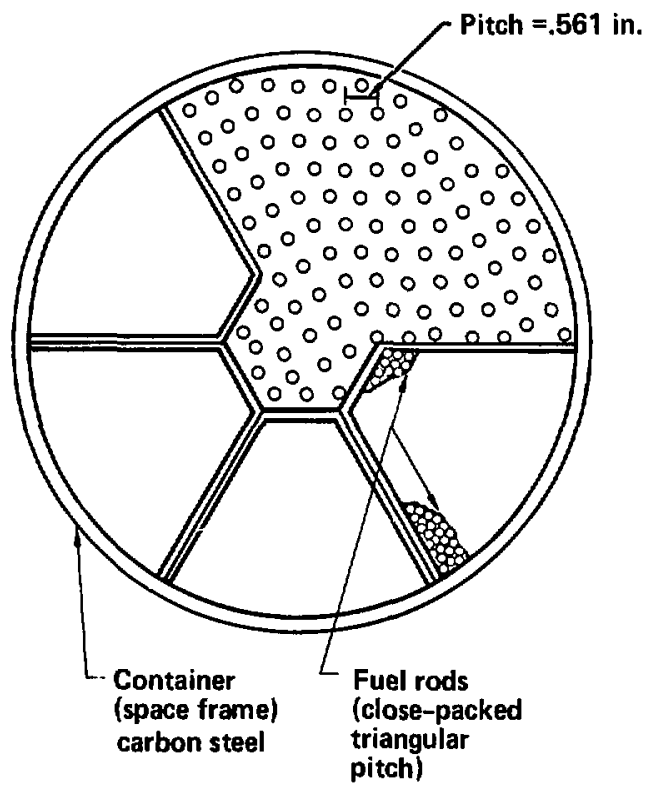

Figure 20. Configuration 6-partial container failure. 


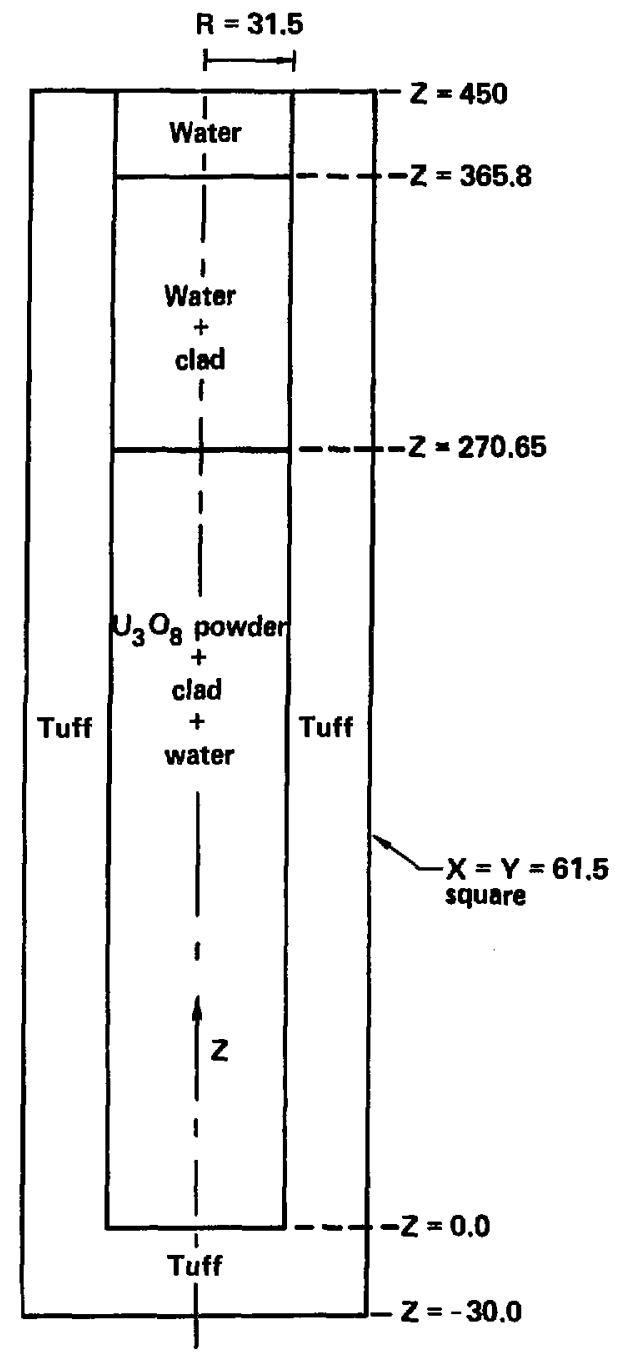

Note: dimensions are in centimeters.

Figure 21. Configuration 10-geometry.

results from irradiation of the fuel. Demonstration of criticality safety in the geologic disposal of spent fuel will also require taking credit for fuel burn-up unless poison rods are placed in the canisters.

The actual reactivity change that results from accounting for fuel burn-up is, of course, depen- dent on many parameters including the fuel type, geometry, initial enrichment, and burn-up. The signif sance of taking credit for fuel burn-up is demonstrated by the results of Weren et al. (1983) and Petrie et al. (1975). These studies showed, respectively, a reduction of approximately $0.01 \Delta \mathrm{k}$ per 1000 megawatt days per metric ton of uranium (MWD/MTU) for PWR assemblies and a $0.188 \Delta \mathbf{k}$ reduction for a fresh-to-21,000 MWD/MTU burnup B\&W $15 \times 15,3.1-w t \%$ U-235 initial enrichment assembly, where $\Delta \mathbf{k}$ is the change in the criticality coefficient.

In this study, where the assumption of fresh fuel resulted in an unacceptable reactivity from a criticality safety point of view, additional KENO calculations were performed for those configurations to define the maximum acceptable equivalent zero burn-up enrichment. Additional calculations using other available codes are beyond the scope of this evaluation; therefore, the maximum acceptable zero burn-up enrichments were compared with existing reactivity-equivalence results. It is concluded, based on this comparison, that sufficient information exists to provide an assessment of the criticality safety, including credit for fissile inventory depletion.

\section{Results}

A total of seven criticality calculations were performed using the Monte Carlo computer code, KENO-IV, involving four geometric configurations and four fuel enrichments. Table 13 summarizes the results of the seven KENO-IV problems.

\section{Conclusions}

Criticality is not a problem for the analyzed consolidated spent fuel waste package stored in a borehole in an unsaturated-zone-tuff geology as long as the fuel rods are maintained in the tightpacked configuration for either dry or totally flooded conditions. However, if the rods spread out and the canister becomes flooded, $k_{\text {ell }}$ increases to unacceptable $\left(k_{\mathrm{ell}}>0.95\right)$ values for fresh fuel or partially depleted fuel. The calculations show that $k_{\text {eff }}$ is always below 0.95 for spent fuel depleted to <1.4-wt\% U-235. The calculations indicate that $k_{\text {eff }}$ will be less than 0.95 unless, as required in NRC 10 CFR 60, two unlikely, independent, and concurrent changes have occurred in the conditions essential to nuclear criticality safety. The changes necessary for $k_{\text {eff }}$ to exceed 0.95 are:

1. The emplaced canister is loaded with spent fuel of equivalent (depleted) loading greater than 1.4-to-1.6-wt\% U-235. (Undepleted fuel rods 
Table 13. Results of KENO-IV analyses.

\begin{tabular}{|c|c|c|c|c|}
\hline & Configuration & $\because$ & $\begin{array}{l}\text { Fuel enrichment } \\
\left(w \mathrm{w}^{\circ} \mathrm{U}^{215}\right)\end{array}$ & $k_{e f l}^{2}$ \\
\hline 1 & Nominal configuration $-\mathrm{dry}$ & & 4.5 & 0.37 \\
\hline 2 & Nominal configuration - flooded & & 4.5 & 0.69 \\
\hline 6. & $\begin{array}{l}\text { Container partially gone - } \\
\text { optimal rearrangement of rods - flooded }\end{array}$ & & 4.5 & 1.18 \\
\hline 6 & $\begin{array}{l}\text { Container partially gone - } \\
\text { optimal tearrangement of rods - flooded }\end{array}$ & & 2.0 & 1.00 \\
\hline 6 & $\begin{array}{l}\text { Container partially gone - } \\
\text { optimal te:drrangement of rods - flooded }\end{array}$ & & 1.0 & 0.79 \\
\hline 10 & $\begin{array}{l}\text { Clad and disintegrated pellets (powder) } \\
\text { optimally mixed - fooded }\end{array}$ & & 4.5 & 1.16 \\
\hline 10 & $\begin{array}{l}\text { Clad and disintegrated pellets (powder) } \\
\text { optimally mixed - flocided }\end{array}$ & & 1.6 & 0.95 \\
\hline
\end{tabular}

${ }^{\wedge} k_{\mathrm{Ulf}}=$ effective neutron multiplication factor.

may be specially handled in the repository. Fuel assemblies are normally depleted to 1.0-to-1.5-wt\%); and

2. The canister is breached and filled with water; and

3. The spent fuel rods or space frame have disintegrated and:

4. a. The spent rods have rearranged into an optimal configuration ( $>1.6-\mathrm{w} t \%$ U-235); or

b. The Zircaloy cladding has disintegrated and all the spent fuel has fallen into a pile (>1.4-wเ\% U-235).

If fresh or pribul; depleted ( $>1.6-w t \%$ U. 235) fuel is emplaced ir: $r$. ference canisters, poison rods will be neec. : w maintain $k_{\text {wi }}<0.95$ in flooded, rearranged conditions (e.g., cases 6 and 10).

\section{Recommendations for Further Analysis}

This evaluation represents an initial assessment of the criticality potential associated with the disposal of consolictated spent fuel in a tuff geology. Additional calculations should be performed to verify and extend the conclusions of this analysis. For disposal of intact assemblies and assemblies consolidated in square-cross-section boxes, further design and analysis is needed. To ensure criticality safety for flooded conditions, it is necessary to place neutron poison material in canisters. Analysis is needed to determine amounts and configurations of poison rods.

\section{Structural Analysis}

To determine if regulatory requirements will be met under normal and accident conditions, structural analysis must address largedeformation, inelastic static and dynamic responses of the waste canister conceptual designs. At the LLNL, three computer codes that meet the above calculational needs are NIKE2D (Hallquist, 1979), DYNA2D (Hallquist, 1984), and DYNA3D (Hallquist, 1981). For two-dimensional axisymmetric static analyses, NIKE2D was used; for twodimensional, axisymmetric dynamic analyses, DYNA2D was used; for three-dimensional dynamic analyses, DYNA3D was used. The DYNA codes require less core storage on the Cray computer than the NIKE code, and thus the DYNA codes were used for the larger problems where NIKE would overflow (Russell and $\mathrm{O}^{\prime}$ Neal, 1984). Other codes used were the mesh generators, MAZE (Hallquist, 1983a), and INGRID (Stillman, 1984), and the post processors ORION (Hallquist, 1983b) and TAURUS (Brown and Hallquist, 1982).

\section{Handling and Retrieval Loads}

To simulate handling and retrieval loading of pour canisters, NIKE2D was used to axially load canisters until yielding occurred. For the WVI DHLW pour canister, the elastic limit was reached at an axial force of $38,000 \mathrm{lb}$ (the yield strength of AISI $304 \mathrm{~L}$ stainless steel is 30,000 psi). This is nine times the package weight $(4300 \mathrm{lb})$, and is greater than the factor of three safety margin required for lifting and retrieval for packages not jammed in boreholes. If WV/DHLW pour canisters were retrieved when wall temperatures were highest $\left(145^{\circ} \mathrm{C}\right)$, the yield strength is about $10 \%$ less (27,000 psi). The margin on yield would be 8 . The current reference design specifies overpacks for 
pour canisters, therefore retrieval loads will not be applied to pour canisters.

Handling and retrieval load analyses of $57-\mathrm{cm}-$ diameter spent fuel canisters indicate that, at $24^{\circ} \mathrm{C}$, an axial load of $92,500 \mathrm{lb}$ is required to produce yielding $(0.2 \%)$. This is approximately 6.3 times the canister weight of $12,597 \mathrm{lb}$. Figure 22 is the finite element mesh of the canister model. Figure 23 shows that maximum stress occurs at the intersection of the lifting pintle outer surface with the canister top head. The yield load on the current design $70-\mathrm{cm}$-diameter canister $(13,800-1 \mathrm{~b}$ weight) is estimated to be about $51,000 \mathrm{lb}$ at $260^{\circ} \mathrm{C}$ using scaling based on a formula for a circular flat plate with center ring load with fixed edges (Roark, 1965). The maximum canister wall temperature expected during the preclosure period is $260^{\circ} \mathrm{C}$. The yield-load-to-can-weight margin would be 3.7 at this temperature.

\section{Fire Test Structural Analysis}

Structural analyses using the computer code NIKE2D were performed to determine if the conceptual design for a $57-\mathrm{cm}$-diameter spent fuel canister meets the proposed NNWSI design requirement for containing the pressure generated inside a canister resulting from an $800^{\circ} \mathrm{C}, 30-\mathrm{min}$ fire test.

For the fire test simulation, the loading configuration consisted of an internal pressure that ranged up to $300 \mathrm{psig}$, which was applied uniformly over the inside canister surface. The results indicate that a maximum effective stress of 9,900 psig occurs at a pressure of 180 psig near the inside corner where the bottom head is joined to the canister wall.

A typical internal helium pressure in PWR spent fuel rods at ambient temperature is on the

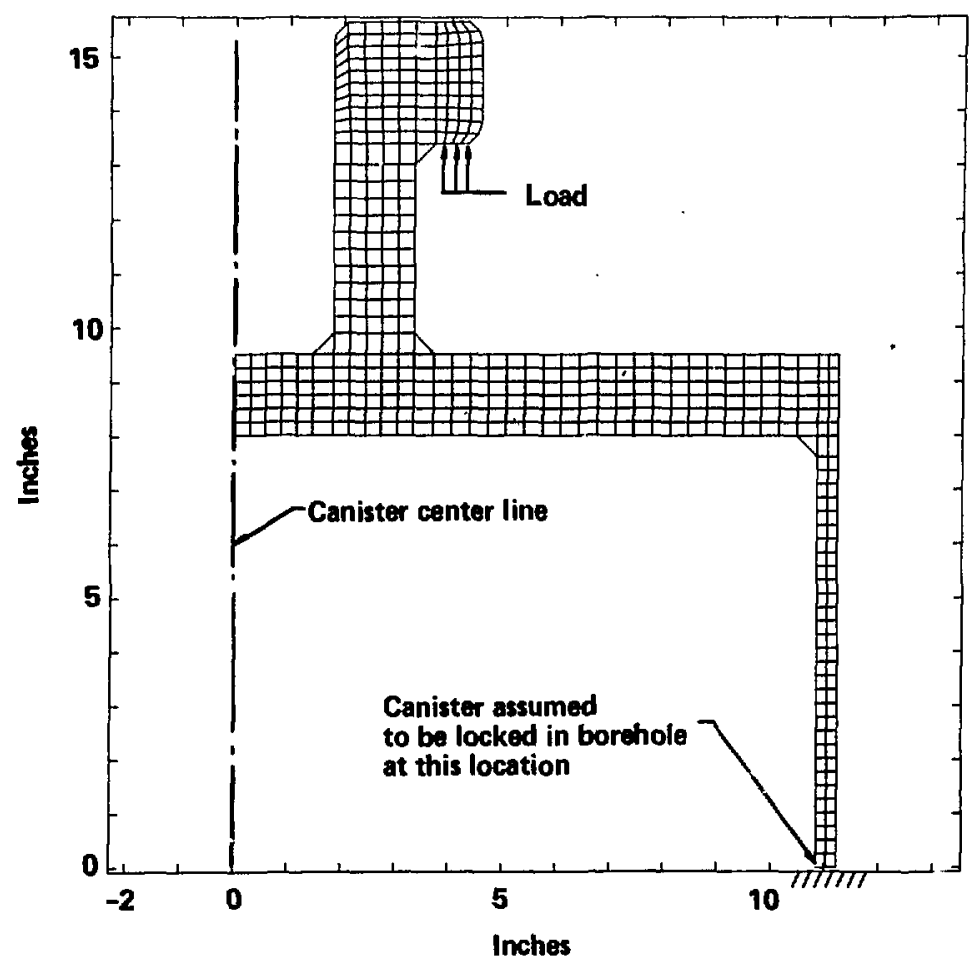

Figure 22. Finite element mesh used to calculate waste package stresses during retrieval. 


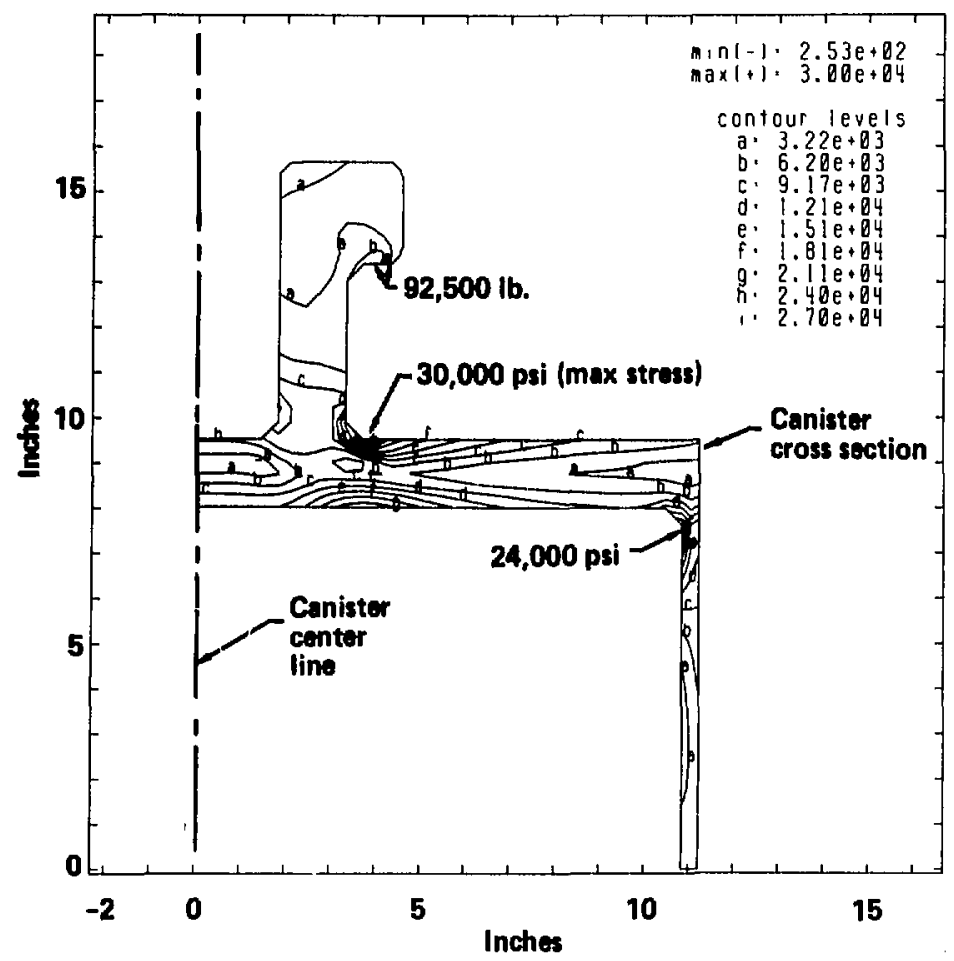

Figure 23. Calculated stress contours on waste package resulting from retrieval loads.

order of 550 psig, although for a small number of rods, the pressure has been reported at more than 1100 psig. The calculated average temperature of 10-year-old spent fuel rods inside the reference canister, in an open area with no radiation shielding at ambient conditions, is about $180^{\circ} \mathrm{C}$. (The canister wall temperature is up to $91^{\circ} \mathrm{C}$ on the sides, about $35^{\circ} \mathrm{C}$ on the top plate and $25^{\circ} \mathrm{C}$ on the pintle). At a temperature of $180^{\circ} \mathrm{C}$ the internal helium pressure of the rods is 845 psig. A calculation using the computer code TACO2D (Stein, 1984) indicates that the fuel rod ends, in contact with air space at the top and bottom of the canister, reach roughly $700^{\circ} \mathrm{C}$ during the $800^{\circ} \mathrm{C}, 30$-min fire test. The hoop stress in the Zircaloy cladding at 845 psig pressure is 5591 psi, which is roughly 5.6 times greater than the Zircaloy yield strength at 700 to $800^{\circ} \mathrm{C}$ ( $\sim 1000$ psi). Thus, pin breaching will occur due to gross yielding and rupture of the Zircaloy cladding. When the volume of helium in the rods is released into a canister (backfilled to $\mathbf{1 4 . 7}$ psia with helium), and then heated to $800^{\circ} \mathrm{C}$, the resulting pressure is $\sim 183$ psig. The maximum effective stress in the canister wall under the above conditions is 9,900 psi (at 180 psig), which is below the 13,000 psi strength of $316 \mathrm{~L}$ stainless steel at $800^{\circ} \mathrm{C}$, and canister breaching would not be expected. Figure 24 shows the stress contours resulting from the $180 \mathrm{psig}$, uniformly applied, internal pressure.

Based on a linear scaling relationship, the stress in the reference $70-\mathrm{cm}$-diameter canister at 180 psig is about 15,000 psi (Roark, 1965, p 217, case 6). This is above the yield stress for 316L but well below the ultimate strength of 20,000 psi at $800^{\circ} \mathrm{C}$, producing a 1.36 margin.

\section{External Pressure (Flooding)}

To simulate the unexpected flooding of the repository, structural analysis of a 57-cm-diameter 


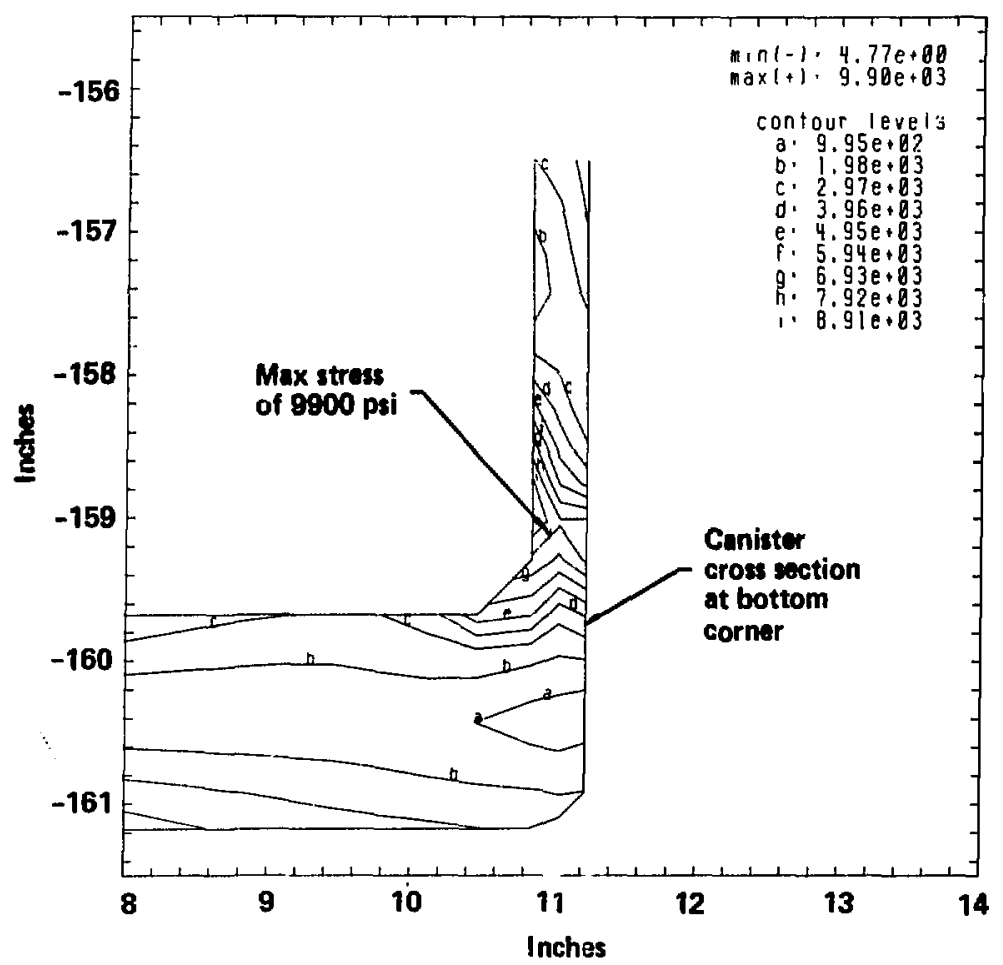

Figure 24. Calculated stress contours on waste package resulting from a fire-test-induced internal pressure of 180 psi.

BWR spent fuel canister under external pressure was carried out using the computer code NIKE2D. Results indicated that compressive yield strain $(0.2 \%)$ of the canister would occur when the pressure reaches 600 psig, which corresponds to $1382 \mathrm{ft}(421 \mathrm{~m}$ ) of water. (Temperatures of canisters are not known for flooding conditions.) The loading configuration consisted of an external pressure that ranged up to $1230 \mathrm{psi}$, which was applied uniformly over the entire outer surface of the canister.

The area of the canister where yielding occurs is near the inside corner where the bottom head is joined to the canister wall. At yield, a stress of 30,000 psi occurs in the bottom head as well as in the canister wall adjacent to where the head is joined. The canister is not expected to breach or collapse at this pressure (600 psig). For a 70 -cmdiameter canister, a pressure of about 40 n psig would cause yielding based on linear scaling with a Roark formula (Roark, 1965, p217, case 5). Temperatures above $100^{\circ} \mathrm{C}$ would reduce the yield strength of austenitic stainless steels.

\section{Drop Test}

The drop test simulation ( $9 \mathrm{~m}$ onto an unyielding surfare) was performed for $57-\mathrm{cm}$-diameter spent fuel canisters. The calculated temperature on the canister surface ranges from $25^{\circ} \mathrm{C}$ to $91^{\circ} \mathrm{C}$. At these temperatures, properties vary little from room temperature values. follows:

Thie results of three drop-test analyses are as

- A test of an empty reference spent fuel canister dropped on its base was simulated using NIKE2D. Rebound occurred $2.7 \mathrm{~ms}$ after a $45-\mathrm{ft} / \mathrm{s}$ impact. The 1-cm-thick side walls of the canister bulged out about $1 \mathrm{~cm}$ (near the base). The peak 
stress was 54,000 psi, which is below the ultimate strength of about 80,000 psi.

- A fully loaded spent fuel canister dropped onto its base was simulated using DYNA2D. Results indicated that bulging of the canister wall occurred adjacent to the base. The peak tifective stress (at roughly $3 \mathrm{~ms}$ after impact) was 68,000 psi. This is above yield but below the ultimate strength of 316L stainless steel. Plastic strain was $21 \%$, which is below the $40 \%$ elongation of 316L stainless steel. Based on these preliminary conservative results, canister beach should not occur in this simulation.

A fully loaded spent fuel canister dropped onto its pintle was simulated using DYNA2D. The maximum stress in the deformed pintle/top plate was $74,000 \mathrm{psi}$, and occurred in the corner between the pintle outside surface and the top plate. The maximum plastic strain was $25 \%$. The stress and strain for this conservative analysis are below failure $(80,000 \mathrm{psi}, 40 \%)$. The top plate temperature is calculated to be about $35^{\circ} \mathrm{C}$ where the tensile strength is not significantly reduced below room-temperature values.

Figure 25 shows graphically the deforinations resulting from a pintle drop and a base drop of a fully loaded spent fuel canister from $9 \mathrm{~m}$ onto an unyielding surface. Stresses in $70-\mathrm{cm}$-diameter canisters would probably be larger and additional detailed analysis will be required.

\section{Future Analyses Needed}

The future structural analyses needed to aid in prototype design will consist of the following:

(a) more two-dimensional analysis of PWR/ BWR spent fuel waste packages with more design detail of waste form;

(b) three-dimensional analyses to include simulation of corner drops of fully ioaded spent fuel canisters onto unyielding surfaces, side drop on a 6-inch-diameter steel post; and

(c) simulation of other scenarios as required to satisfy additional regulatory requirements.

\section{Labeling}

Identificatior, information for the spent fuel or WV/DHLW in each canister will be placed on the top plate or top surface of the pintle during packaging. The label can be in the form of an embossed, machined or etched stainless steel plate welded or mechanically attached. Alternatively, the information can be etched or machined directly onto the top plate or pintle. The letter size will be large and deep enough to be read at a distance and large and deep enough not to be corroded beyond legibility during the operational period of the repository. Other options include binary-coded dimples or some kind of bar code. No difficulties are expected in meeting the permanent labeling requirement.

\section{Design Performance}

In this section, each reference and alternative design is evaluated relative to the design requirements given in the section under "Regulatory Requirements for Waste Package Design". Some of the material given in this section has been covered elsewhere in the report undel iscussion of ther. mal, structural, and criticality safety analysis. Ir this section, the material is organized around designs rather than topics. The objective here is to show that each design meets requirements, or to identify areas of designs where more analysis is needed to show conformance to requirements. In this report, containment and release-rate performance are not analyzed. Future reports will discuss long-term performance.

\section{Spent Fuel Canisters}

Containmen Period - Waste Package Containment. (Not covered in this report).

Isolation Period - Control of Radioactivity Release Rate. (Not covered in this report).

Retrievability Period. The waste package shall be designed to be retrievable for 50 years after emplacement of the first waste package. Structural analysis of the pintle and canister strength of a 57$\mathrm{cm}$-diameter canister indicates that a retrieval force of $92,500 \mathrm{lb}(355 \mathrm{kN})$ can be applied to the pintle without exceeding the room temperature yield strength of $316 \mathrm{~L}$ stainless. For the advanced conceptual design canister $(70 \mathrm{~cm}$ diameter, $14,000 \mathrm{lb}$ ), the yield load is $51,000 \mathrm{lb}$ at $260^{\circ} \mathrm{C}$, which is the maximum canister wall temperature. This is about 3.6 times the canister weight and is corsidered adequate (including a safety margin) to retrieve canisters from either vertical or horizontal boreholes without breach, under expected retrieval conditions.

The analysis on the $57-\mathrm{cm}$ canister was done using NIKE2D, a finite-element, two-dimensional structural-analysis code (see the section under "Structural Analysis"). The assumption was made that there was no reduction in wall thickness and that there were no cracks or pits present 

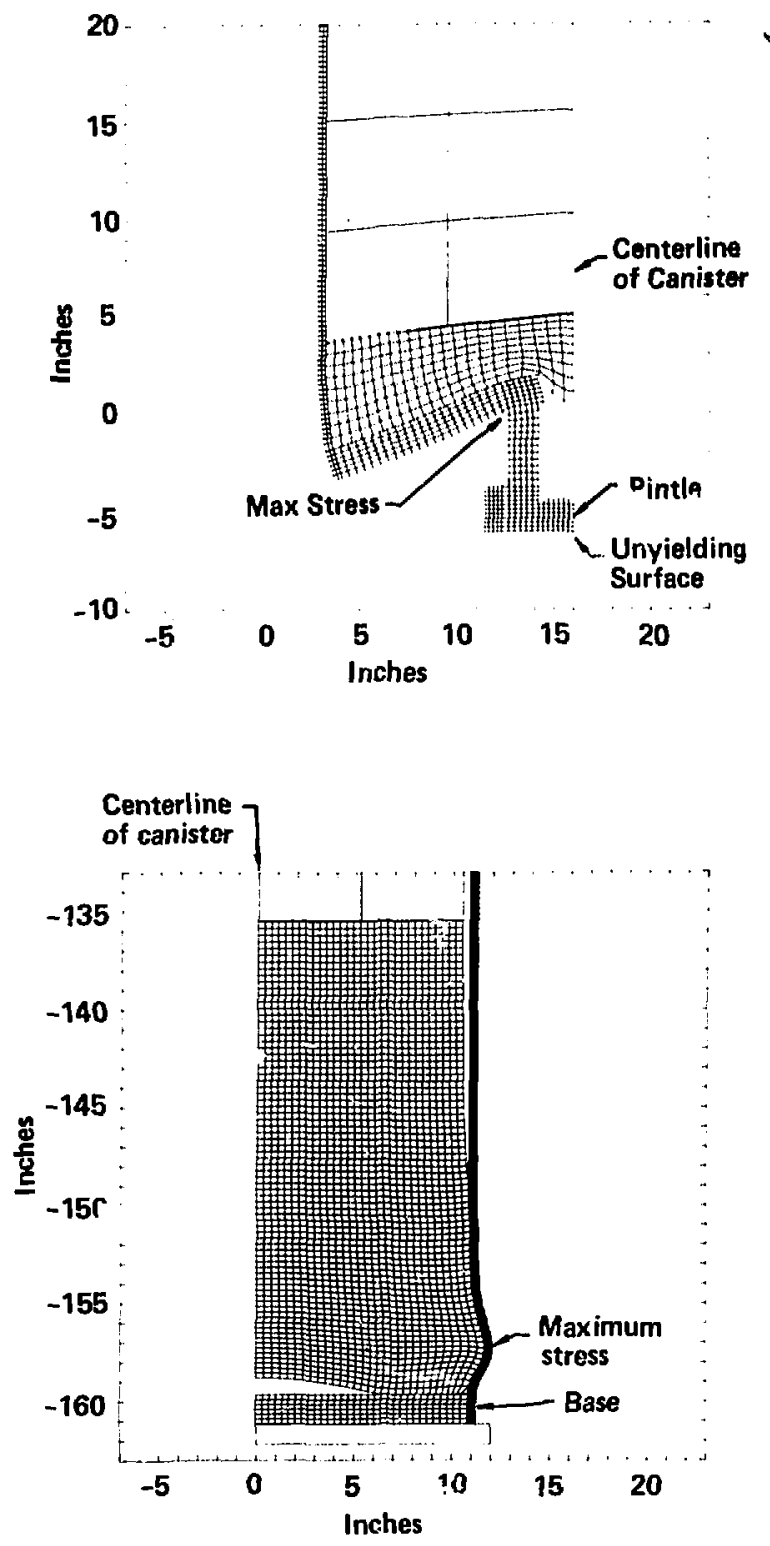

Figure 25. Calculated canister deformations resulting from a simulated drop test. 
in the canister and pintle, as a result of corrosion. The amount of corrosion anticipated in 50 years is not expected to significantly reduce canister strength.

Based on the results of analysis on the $57-\mathrm{cm}$ diameter canister, the 70-cm-diameter canister used with preconsolidated rods and with canisters used in conjunction with packing, can be detail designed to have the same or greater strength. Therefore, it is expected that final designs of all spent furl canisters will be strong enough to meet the normal retrievability requirements in vertical or horizental emplacement configurations. Normal conditions are defined as those in which boreholes have not collapsed to a degree that would prevent withdrawal of canisters without exceeding allowable pintle loads.

Criticality Control. Criticality is to be controlled so as not to exceed an effective multiplication factor $\left(k_{\text {eff }}\right)$ of 0.95 unless more than two unlikely changes occur. A criticality analysis of a spent fue! canister containing six PWR consolidated assemblies indicates that $k_{\text {wr }}$ of 0.95 would be exceeded only under a combination of flooding and several other conditions. No two changed conditions would cause a higher than allowable $k_{\text {wn }}$. Therefore, the design meets the criticality safety requirements (see the section under "Criticality Analysis").

The analysis was done on a 57-cm-diameter canister containing six PWR assemblies. Based on the resul 5 of this analysis, it is expected that BWR canisters, and canisters vith larger or smaller diameters (which contain less waste), will also meet the criticality requirements. However, the void space in canisters containing close-packed, consolidated SF provides room for fuel rods to spread out and reposition into more reactive geometries when water (moderation) is present. To help avoid reactivity increases, detailed designs of spent fuel canisters will include neutronabsorbing poison rods consisting of boron carbide in Zircaloy tubes.

For intact assemblies, the pin spacing is at an optimum for criticality in flooded conditions. Final designs will include neutron-absorbing poison rods in canisters containing intact assemblies to keep $k_{\text {m }}$ below 0.95 .

Temperature Limitations. Temperatures are to be kept below limits for the waste forms, which are $773 \mathrm{~K}\left(500^{\circ} \mathrm{C}\right)$ for WV/DHWL glass, $673 \mathrm{~K}$ $\left(400^{\circ} \mathrm{C}\right)$ for $\mathrm{CHLW}$ glass, and $623 \mathrm{~K}\left(350^{\circ} \mathrm{C}\right)$ for spent fuel cladding. To avcid degradation of waste forms, upper temperature limits have been estab- lished. Waste packages are to be designed to avoid exceeding the limits, taking all uncertainties into account. This section shows that the peak temperatures of current reference and alternative designs are expected to be below the temperature limits of $350^{\circ} \mathrm{C}$ for spent fuel at $50 \mathrm{~kW} /$ acre.

Reference Design Spent Fuel Canisters Consolidated Assemblies. The temperature limit established by NNWSI for spent fuel is $350^{\circ} \mathrm{C}$ ( to prevent degradation of the Zircaloy cladding). A number of parameter studies have been made using TACO2D and TACO3D to calculate waste package temperatures (see the section under "Thermal Analysis"). The studies indicate that reference $3.3-\mathrm{kW}, 70-\mathrm{cm}$-diameter waste packages containing 6 PWR or 14 BWR consolidated assemblies can be emplaced vertically or horizontally at $48 \mathrm{~kW}$ per acre or more without exceeding $350^{\circ} \mathrm{C}$. For horizontal emplacement at $48 \mathrm{~kW} / \mathrm{acre}$, canisters probably cannot be placed touching end-toend, but must be spaced apart, and this results in more boreholes (see below). Therefore, the reference spent fuel canister designs meet the temperature limit requirement. (No backfill is used in the reference and most of the alternative designs).

Preconsolidated Spent Fuel. Thermal analysis was performed on horizontally emplaced, preconsolidated assemblies packaged into $68-\mathrm{cm}$ diameter canisters. For end-to-end emplacement in boreholes spaced $52 \mathrm{~m}$ apart ( $40.6 \mathrm{~kW} /$ acre) the peak fuel temperature was $330^{\circ} \mathrm{C}$ (see Table 11 , case 22). If the spent fuel is emplaced at higher areal power densities, the peak fuel temperature will increase. Further analysis is needed to determine whether this design will have a temperature sufficiently below the $350^{\circ} \mathrm{C}$ limit at over $40.6 \mathrm{~kW}$ / acre with end-to-end spacing. If not, canister spacing can be increased and borehole spacing de$c$ coased to more evenly distribute the heat.

Intact Assemblies. The reference case for intact assemblies is the mixing of these canisters with consolidated spent fuel canisters. The canister is $70 \mathrm{~cm}$ in diameter and contains 6 PWR or 12 BWR intact assemblies $(1.65 \mathrm{~kW})$ with no backfill. The calculated peak temperature for 3 PWR assemblies is $295^{\circ} \mathrm{C}$ at $40.6 \mathrm{~kW} /$ acre (case 23). At 57 $\mathrm{kW} / \mathrm{acre}$, the peak temperature is expected to be well below $350^{\circ} \mathrm{C}$. Therefore, the design meets temperature limit requirements.

Alternative Spent Fuel Canister with Containerized Packing. Spent fuel may require packing to meet the release rate requirement. Due to the low thermal conductivity of the packing, the 
amount of waste per canister must be reduced to lower the thermal power below the temperature limit of $350^{\circ} \mathrm{C}$. A canister has been designed that contains four 10-year-old PWR consolidated assemblies. The canister is surrounded by a container holding a 15-cm thickness of crushed compressed tuff to surface-absorb radionuclides. No backfill is placed around the packing container.

Thermal analysis of this design (case 21) emplaced horizontally end to end at $42 \mathrm{~kW} /$ acre areal power density (APD) resulted in a peak pin temperature of $326^{\circ} \mathrm{C}$. Since this value is sufficiently below the temperature limit, the design meets the requirement. Higher areal power density may be possible for more uniformly spaced canisters and for canisters emplaced in the verticalemplacement configuration.

Drop Test Requirements. Waste packages shall be designed to preclude leakage of radioactive material in sxcess of applicable state and federal standards after undergoing drop tests onto an unyielding surface, at the minimum anticipated temperature.

NNWSI has selected some of the drop test requirements of $10 \mathrm{CFR} 71$ (Transportation of Radioactive Materials) against which to compare waste package strength. This is conservative because 10 CFR 71 drop tests are done with the waste canister inside the shipping cask. NNWSI is designing waste canisters to contain waste after a 30 -ft drop test when separate from a shielding transporting cask. This will provide safety in hot cell and emplacement operations when the canisters are not protected by the cask.

Structural analysis has been performed on a $57-\mathrm{cm}$-diameter $\times 4.5-\mathrm{m}$-long spent fuel canister at room temperature. In the first case, a fully loaded spent fuel canister dropped onto its base was simulated using the elastic-plastic, dynamic computer code DYNA2D with a two-dimensional, axisymmetric mesh. Results indicated that bulging of the canister wall occurred adjacent to the base. The peak stress (at $3.2 \mathrm{~ms}$ after impact) was $68,000 \mathrm{psi}$. This is above yield but below the ultimate strength of $316 \mathrm{~L}$ stainless steel. Plastic strain was $21 \%$, which is below the $40 \%$ maximum elongation. Based on these preliminary results, canister breach did not occur in this simulation.

In the second case, a computer simulation was performed on the same canister design dropped on its pintle from a height of $30 \mathrm{ft}$. The maximum stress in the deformed pintle/end plate was 74,000 psi with a strain of $25 \%$. The stress and strain are below failure $(80,000 \mathrm{psi}, 40 \%)$.
This was a severe drop test configuration and stresses were approaching the ultimate strength of 316L stainless steel. Drops on corners of the canister may be more severe. At present we have not developed criteria for design safety margins for drop tests. It may not even be likely that bare canisters will be raised to a height of $30 \mathrm{ft}$ during handling. This will not be known until subsurface and surface facility conceptual design is further along.

The reference material, austenitic stainless steel has satisfactory fracture toughness, strength, and ductility at the expected minimum temperature at Yucca Mountain of $-18^{\circ} \mathrm{C}$. Physical properties and strength of austenitic stainless steels vary from $-18^{\circ} \mathrm{C}$ to $+100^{\circ} \mathrm{C}$, but based on the room temperature analysis and comparison with properties over this temperature range, the current concepts perform without breach, and could be detail designed to increase safety margins for prototype and final designs.

Fire Teut. The waste package shall be designed to prevent leakage of radioactive material after sustaining a $1073 \mathrm{~K}\left(800^{\circ} \mathrm{C}\right), 30$-min fire test. A computer simulated fire test analysis was performed on a canister (without cask) containing spent fuel with a thermal loading of $3.42 \mathrm{~kW} / \mathrm{pkg}$. An $800^{\circ} \mathrm{C}$ constant temperature boundary condition was applied to the outer surface of the canister for a period of 30 min using TACO2D.

The maximum temperature reached in the air space in $30 \mathrm{~min}$ was $787^{\circ} \mathrm{C}$; the top of the fuel rods reached. a temperature of $705^{\circ} \mathrm{C}$ in $30 \mathrm{~min}$. The geometric center of the fuel rod bundle was not affected in the relatively short time of the fire test. The calculated temperatures were then used in structural analysis of the canister.

A significant pressure increase occurs during the fire test. A typical internal helium pressure in PWR spent fuel rods at ambient temperature is on the order of $550 \mathrm{psig}$, although for a small number of rods, the pressure has been reported at over 1100 psig. A calculation using the computer code TACO2D indicates that the average temperature of 10-year-old spent fuel rods inside the reference canister, in an open area with no radiation shielding at ambient conditions, is about $180^{\circ} \mathrm{C}$. At this temperature the internal helium pressure of the rods is 845 psig. In another TACO2D analysis, fuel rod ends, in contact with air space at the top and bottom of the canister, reach roughly $700^{\circ} \mathrm{C}$ during the $800^{\circ} \mathrm{C}, 30$-min fire test. The hoop stress in the Zircaloy cladding at 845-psig pressure is 5591 psi, which is roughly 5.6 times greater than the Zircaloy yield strength at 700 to $800^{\circ} \mathrm{C}$ 
$(\sim 1000$ psi). Thus, helium release will occur due to gross yielding and rupture of the Zircaloy cladding. When the volume of helium in the rods is released into a canister (backfilled to 14.7 psia with helium), and then heated to $800^{\circ} \mathrm{C}$, the resulting pressure is 183 psig. The maximum effective stress in the canister wall under the above conditions is 15,000 psi, which is below the 20,000 psi ultimate tensile strength of $316 \mathrm{~L}$ stainless steel at $800^{\circ} \mathrm{C}$, and canister breaching would not be expected. Based on these results, the SF canister design is expected to meet the fire test specifications given in 10 CFR 71. Safety margins could be increased by increasing the canister end plate corner thickness where the stress concentration occurs.

Canister Integrity. The waste package shall be designed to prevent leakage of radioactive material in excess of applicable federal and state standards under expected loads during or after transportaticn, handling, emplacement, retrieval, and seismic events. Further, these loads must not compromise long-term performance.

The loads normally expected during transportation at the repository, handling, emplacement, retrieval, and seismic events are small compared to impact loads during drop tests. The normal loads imposed on the pintle and canister body during retrieval and lifting are no more than two times canister weight. The resulting stresses are estimated to be well below yield (see the section under "Retrieval Loads"). Seismic loads are not expected to exceed $1 \mathrm{~g}$, and will result in stresses well below yield.

A 70-cm-diameter canister was analyzed as a simply supported beam using an analytic beam stress formula. For a canister lying on its side, loaded to five times canister weight, the calculated stress was about 7000 psi, which is well below the allowable yield stress of $19,000 \mathrm{psi}$ at $260^{\circ} \mathrm{C}$.

To simulate the unexpected event of deep flooding of the repository, a structural analysis of a BWR spent fuel canister under external pressure was carried out. Results indicated that yielding of the $70-\mathrm{cm}$-diameter canister will begin when the pressure reaches $400 \mathrm{psig}$, which corresponds to $923 \mathrm{ft}(281 \mathrm{~m})$ of water. The loading configuration consisted of an external pressure that ranged up to $1230 \mathrm{psi}$, which was applied uniformly over the entire outer surface of the canister. The canister is not expected to breach or collapse at this pressure.

Federal Tranoportation Regulatory Requirements. Nuclear waste shipped from utilities and from West Valley, N.Y. or Savannah River will be shipped in NRC-licensed shipping casks and liners designed by organizations other than NNWSI. Waste will not be shipped to the repository in NNWSI canisters or overpacks that are not specifically designed to meet Federal transportation regulatory requirements (NRC 10 CFR 71 ). If WVI DHLW pour canisters form the liner of a shipping cask, the design and licensing responsibility for the pour canister will fall under an organization other than NNWSI. The pour canister will not become the disposal canister because it will be overpacked in another container designed to meet the NRC 10 CFR 60 requirements as given in this report.

\section{West Valley/Defense High Level Waste Packages}

The WVIDHLW pour canister $(61 \mathrm{~cm}$ in diameter by $300 \mathrm{~cm}$ long) will be overpacked in an austenitic stainless steel overpack identical in design to the SF canister. The length of the overpack is $324.5 \mathrm{~cm}$ including pintle, which is shorter than the shortest SF canister $(4,0 \mathrm{~m})$. The preceding section, "Spent Fuel Canisters" shows the acceptable design performance of this container with heavier loads and higher powers than that of WVI DHLW. Therefore, since the preclosure design performance of the detail-designed SF canister is expected to meet all requirements, it should also meet requirements when used as an overpack for WV/DHIW.

Some thermal calculations have been completed. These results show peak temperatures of the glass to be considerably lower than the allowable $500^{\circ} \mathrm{C}$ temperature for the WV/DHLW reference canister.

\section{Commercial High LeveI Waste Packages}

The reference design for CHLW consists of a CHLW pour canister $32 \mathrm{~cm}$ in diameter by $300 \mathrm{~cm}$. long overpacked in an austenitic stainless steel canister nearly identical in design to the SF canister. The overpack is $36 \mathrm{~cm}$ in diameter by $324.5 \mathrm{~cm}$ long.

The relevant preclosure design performance analysis done for the heavier, larger SF canister indicates that the $\mathrm{CHLW}$ reference waste package concept can be detail designed to meet all requirements. Thermal analysis done on CHLW indicates no problem in staying under the $400^{\circ} \mathrm{C}$ temperature limit in the reference repository configurations for vertical and horizontal emplacement. 


\section{Consideration of Desirable Design Characteriatics}

\section{Standardization}

Standard sizes and shapes have been considered in conceptual design, but it will be more important to select standard sizes and shapes during final design. Standard, commercially available metals have been selected for the conceptual design.

Standard ASTM/AISI specifications will be required in the detailed drawings and specifications for the waste package. Also standard fabrication specifications will be used in welding, quality assurance, nondestructive testing and other applicable areas of canister manufacturing. NNWSI will develop design and testing specifications for waste package design or will use Office of Civilian Radioactive Waste Management (OCRWM) specifications when they become available.

\section{Design Simplicity}

No unnecessarily complicated design features are extant in the designs.

\section{Technical Coniservatism}

Various alternative designs have been considered and analyzed for thermal, criticality, and structural performance.

Thermal Design. The amount of spent fuel in a waste package and the spacing between waste packages has been restricted to avoid exceeding the temperature limit of $350^{\circ} \mathrm{C}$, which is a conservative number. To allow for uncertainty in data and analysis, design temperatures are conservatively limited to about $335^{\circ} \mathrm{C}$. Accurate two-dimensional and three-dimensional heat transfer codes have been used in the analysis.

Criticality Control. Detailed criticality safety analyses of early conceptual consolidated spent fuel canister designs were carried out. The results showed that after canister and space-frame degradation over time, fuel pins could rearrange into potentially higher $k_{\text {ff }}$ configurations (in the presence of water) due to empty spaces inside the ranister. For conservatism, space frames were redesigned to include neutron-absorbing poison rods to improve criticality control.

Structural Design. Detailed 2D structural analyses were performed of SF canister-design re- sponses to accident and flooding conditions. Design modifications were made which resulted in canisters that can withstand such environments without breaching. However, more modifications are needed to reduce impact stresses in canisters which occur in 30-foot drop tests. Although a breaching condition (excess of ultimate strength) did not occur, stresses near ultimate were encountered in the drop-test simulations. The siresses probably should be lowered to more conservative values, and such action is planned for the advanced conceptual design or preliminary design phase.

Materfal Selection. The reference canister material, an austenitic $S S$, has been conservatively selected because of its excellent corrosion resistance, fabricabllity, strength, ductility, and fracture toughness over a wide temperature range. It has been used extensively in critical applications in chemical, nuclear, and other fields, and is commercially available at economical prices.

In case one of the candidate austenitic stainless steels develops problems during long term corrosion testing, other candidate materials with excellent properties have been designated. These include 316L, 304L SS, 321 SS, Incoloy 825, and 7030 cupro-nickel.

\section{Conventional Materials and Fabrication Techniques}

Thie spent fuel canisters and pour canister overpacks are designed with conventional materials and fabrication processes. The candidate materials, 516L stainless steel, 304L, 321, Incoloy 825 and copper-nickel alloy are not unusual in composion or microstructure. Normal forming, machining, and welding techniques can be used in fabricating the designs. Copper is less easily welded than the other materials.

The alternative design waste package with compressed tuff packing is not converitional. To our knowledge, compressed tuff sand has never been used. Samples have been fabricated and tested at LLNL in 1984. If this alternative is necessary for spent fuel, which currently appears unlikely, research and development will be conducted to demonstrate the feasibility of compressed tuff for use as a radionuclide sorbent in the NNWSI repository. 


\section{Compatibillity with Whate Procesoing. Tranoportation, Consolidation, and Emplacement Operations}

The conceptual waste package designs are computible with other interfacing systems. Compatikility is designed into waste package configurations based on the needs of, and physical interfaces with waste processing, storage, transportation, handling, consolidation, emplacement, possible retrieval, and permanent disposal. LLNL maintains awareness of the needs and interfaces by keeping abreast of NRC and OCRWM developments through meetings, telephone discussions, seminars, workshops, conferences, informal and formal interfacing workshops with NNWSI project participants, with emphasis on Sandia National Laboratory (SNL) interfaces. Exchange of formal and informal reports, letters and memos occurs frequently between SNL, LLNL, and other NNWSI participants.

Some of the specific physical interfaces that have been thoroughly coordinated are pintle/ grapple compatibility, spent fuel consolidation and assembly into space-frame configurations, canister/cask/borehole diameters, canister diameter standardization, canister welding and QA procedures, emplacement and retrieval scenarios, compatibility with grout, thermal effects on the repository host rock, and compatibility with the near field environment in the repository.

\section{Cost Effectiveness}

Nuclear waste package economics codes for the numerous design and emplacement options being considered for the NNWSI program have been brought to an initial stage of completion and a large number of runs have been made to evaluate economic impacts of different design options. All costs shown are in 1983 dollars and have not been adjusted for inflation, interest rate or year of expenditure.

As a result of these analyses and subsequent design changes, cost effectiveness has been achieved in waste package design by the following:

1. Working towards a design suitable for horizontal emplacement, which reduces mining costs by over $\$ 800 \mathrm{M}$ compared to vertical emplacement (Scully, 1984).

2. Choice of an austenitic stainless steel for the reference canister material based on several technical factors including material cost.

3. Maximizing the diameter (and contents) of the canisters consistent with not exseeding the temperature limit.
4. Standardizing the diameter of the canisters to a single diameter and pintle to simplify handling fixtures, transport casks, etc.

5. Using a single type design for the space frame (square holes) instead of two types (square hole and pie-shape radial fins). Although this increases canister diameter for repository consolidated rods, it simplifies consolidation operations.

6. Not selecting more costly designs such as (a) the self-shielded design; (b) another design consisting of a titanium sheath over a carbon steel reinforcement; and (c) a large-diameter canister containing three WVIDHLW pour canisters.

Model Development Approach. The basic approach employed to formulate the economics codes was to jrogram a set of spread sheets on a Northstar Horizon personal computer using the commercially available Supercalc software. A separate spread sheet was programmed for each major design change and was used to calculate the effects of dimensional variations for that particular design.

The calculations include the direct cost of space-frame and waste-package fabrication, borehole plugs, the costs for SF rod consolidation, processing, and emplacement of the waste package in the repository, and the incremental mining, muck handling, drilling, and ventilation costs associated with the emplacement of each additional package and the cost of additional facilities required for vertical emplacement (Scully, 1983a). All these are affected by the waste package because changes in package design can result in significant changes in emplacement costs due to changes in the emplacement hole diameters as well as their spacing along the mined drifts. Thus, package design and specific emplacement configuration are tightly coupled and must be evaluated together as a system in order to properly assess the economic impact of specific waste package design changes. However, no attempt is made to incorporate all the repository costs, such as the cost of surface facilities (other than consolidation facilities), since such costs are not prescrtly known and change very little for the design variations presented in this report, except for costs of consolidation of spent fuel. Such costs are to be included in the overall repository conceptual design and cost evaluation being developed by Sandia National Laboratories, Albuquerque.

Cost Data and Sources.

Waste Package Costs. We were unable to identify any significant cost difference between $316 \mathrm{~L}$ and 321 stainless steels, and thus they are 
treated as being the same cost throughout the analysis.

Glass Pour Canister Costs for WV/DHLW and CHLW. The glass pour canister costs were obtained from a Westinghouse cost study and used without change. They are given in Table 14 .

Cylinder and End Cap Costs. These costs were estimated by calculating the weight of the cylinder and end caps from their dimensions and density and then computing their individual costs using estimated cost per pound numbers for each provided by Russell et al. (1983). This cost per pound information is presented in Table 15.

Welding Coats. It is assumed that the welding costs will scale with the volume of the weld. It is also assumed that the width of the weld will increase linearly with the thickness of the material. Therefore, the volume of the weld will increase proportionally to the length times the thickness of the material squared. It was estimated that welding canister circumferential joints would cost approximately $\$ 3.18 / \mathrm{in}^{3}$ of weld. Thus the welding cost $C$ in dollars was calculated with the following equation:

$C=\pi \times D_{\mathrm{can}} \times t_{\mathrm{can}}^{2} \times s$

where $D_{\text {can }}$ is the diameter and $t_{\text {ran }}$ is the thickness of the canister (weld) in inches at cost per unit volume $s$ in \$lin?.
Pintle Costs. It was estimated that the pintle would cost approximately five hundred dollars to fabricate and eighty dollars to weld on to the end cap.

Space-Frame Costs. To estimate the direct (material plus labor) cost of a space frame, its weight was calculated and multiplied by a unit cost of \$3/lb.

Shipping Costs. Westinghouse estimated that shipping costs external to the repository will be approximately $\$ 0.10 / \mathrm{lb}$.

Overhead Coste. The overhead costs were calculated as a fixed percentage of the direct canister, space- $f_{1}$ ame, and overpack manufacturing costs. It was estimated that such costs, including $10 \%$ for quality assurance and general administrative overhead, would run approximately $50 \%$ of the direct manufacturing costs. This percentage is consistent with estimates made by Westinghouse (1983).

Steel Hole Liner Costs. Scully et al. (1983a) estimated that the fabricated and installed 3/4-in.wall steel hole liner for the horizontal emplacement holes would cost $\$ 890$ /waste package. Therefore, the cost of the steel hole liner per waste package was calculated from the cost per waste package times the number of emplaced packages.

Repository Handling Costs. There are a number of costs that can be attributed to the handling of the waste packages after they reach the repository. The ones that have been included in the

Table 14. Pour canister coste for WV/DHLW and CHLW (\$/canistex) including matexial, labor, overhead, shipping, and profit.

\begin{tabular}{lccc}
\hline & \multicolumn{3}{c}{ Pour canister material } \\
\cline { 2 - 4 } Waste form & $304 \mathrm{~L}$ & 316L or 321 & 1825 \\
\hline WVIDHIW & 5,183 & 6,328 & 14,049 \\
CHLW & 3,231 & 3,899 & 7,935 \\
\hline
\end{tabular}

Table 15. Cylinder and end cap unit coats (\$/1b) for overpacka and canisters.

\begin{tabular}{lccc}
\hline Part & & Material & \\
\cline { 2 - 4 } & 304L & 316L or 321 & 1825 \\
\hline Cylinder & 2.14 & 2.50 & 6.07 \\
End caps & 2.86 & 3.21 & 7.80 \\
\hline
\end{tabular}


cost estimates presented in this report are given below.

Waste Package Processing. Waste package processing includes receiving, transporting, labeling, surface storage, and general accounting for each package at the repository. Westinghouse has estimated this cost to be approximately $\$ 3800$ per package (Westinghouse, 1983).

Canister and Overpacking Labor. There will be an additional labor cost for placing the SF assemblies in canisters and overpacking of WVI DHLW and CHLW pour canisters. Westinghouse has estimated this cost to be approximately $\$ 4250$ per waste package for the reference canisters containing 6 PWR or $18 \mathrm{BWR}$ assemblies. It is assumed that this cost will vary in proportion to the number of assemblies in the waste package.

Spent Fuel Rod Consolidation. In the event that the spent fuel rods are consolidated, there will be an additional labor cost for this consolidation process. Westinghouse has estimated this cost to be approximately $\$ 21,000$ per canister for the reference canisters containing 6 PVVR or 14 BWR assemblies. However, LLNL esimates this cost to be much lower at $\$ 3000$ per canistor (40 man hours @ \$75/hr). * The consolidation !'st cells are estimated at $\$ 100$ million (Stearns-Roger, 1983). For 26,000 canisters of $S F$ and 5000 canisters of SF hardware, this amounts to $\$ 3226 /$ canister. It is assumed that this cost will vary in proportion to the number of assemblies in the waste package.

Subsurface Facilities Costs. Costs of the following subsurface construction were included in the calculations (Scully et al., 1983a):

\begin{tabular}{lll} 
& \multicolumn{1}{c}{$\begin{array}{c}\text { Vertical } \\
\text { Emplacement }\end{array}$} & $\begin{array}{c}\text { Horizontal } \\
\text { Emplacement }\end{array}$ \\
Mining and muck handling & $\$ 0.88 / \mathrm{ft}^{3}$ & $\$ 1.65 / \mathrm{ft}^{3}$ \\
Drilling & $\$ 39.80 / \mathrm{ft}^{3}$ & $\$ 27.33 / \mathrm{ft}^{3}$ \\
Additional facilities & $2.3 \mathrm{M}$ & - \\
Ventilation & $215.3 \mathrm{M}$ & $53.6 \mathrm{M}$ \\
Emplacement (including plug) & $101.8 \mathrm{M}$ & $23.8 \mathrm{M}$
\end{tabular}

Total unit cost for a waste package was generally based on Scully's total costs divided by the number of waste packages. (Scully's totals were based on 59,000 waste packages). For intact assemblies, unit costs were based on 52,000 packages, and 31,000 waste packages for consolidated

\footnotetext{
* Based on a throughput of 2-3 canisters/shift with 12-13 people (direct labor) operating a hot cell.
}

spent fuel, including $\mathbf{5 0 0 0}$ canisters of spent fuel hardware. For WVHLW, 300 canisters were assumed. A more recent schedule (Table 3) gives a total of 26,359 consolidated packages, 4265 intact packages and 310 WVHLW packages.

Table 16 gives a summary of comparative costs for vertically emplaced reference and alternative designs for a 70,000 MTU repository. Table 17 displays the entire spread sheet for these calculations. The study is intended to show cost comparisons between: bare pour canisters ( $\mathrm{col} F$ ) and overpacked pour canisters (col G); and consolidated SF (col H, I, and J) and intact SF (col K and $\mathrm{L})$. The actual planned quantities of waste include both intact and consolidated SF (see Table 3).

\section{Conclusions and Recommendations}

The analyses discussed in this report were performed to determine if current (at-the-time-ofanalysis) concepts met an NNWSI nominal set of then-current requirements and design bases. Over the period the work was done, there was an evolution of these parameters. Based on the results of the analyses, it is concluded that the now-current concepts can be detail designed to meet any similar set of final requirements.

The final design for strength during normal handling and design-basis accidents will depend on the final requirements for drop testing and fire testing, on the final material selection, and on the safety margins required on stress and strain during these tests.

The final design of spent fuel waste packages for criticality control depends on interpretation of NRC 10 CFR 60 and on specific scenarios for changes in the waste package and its long-term environment. The numbers of poison rods and their locations in the waste package need to be determined and documented by analysis.

Further two-dimensional and threedimensional thermal analyses are needed to determine the optimum arrangement of canisters in vertical and horizontal emplacement. Borehole and drift spacing should be determined for each class of waste, e.g., 5-year-old, 10-year-old, high burnup, average burnup, intact, consolidated waste.

Cost-effectiveness studies with more accurate data and more systems cost factors need to be performed. The costs calculated to date are probably accurate enough for decisions concerning gross 
design viriations. Work is needed to more accurately $d$ stermine the cost of spent fuel consolidation as it is affected by canister and space frame designs. The optimum spacings of emplaced waste packages are determined by cost as well as ther- mal analysis. Finally, consideration should be given to appropriate discount rates for waste packages and rel-ted facilities costs when making decisions on consolidation vs nonconsolidation of spent fuel.

Table 16. Summary of waste package (WP) and related costs for vertical emplacement.

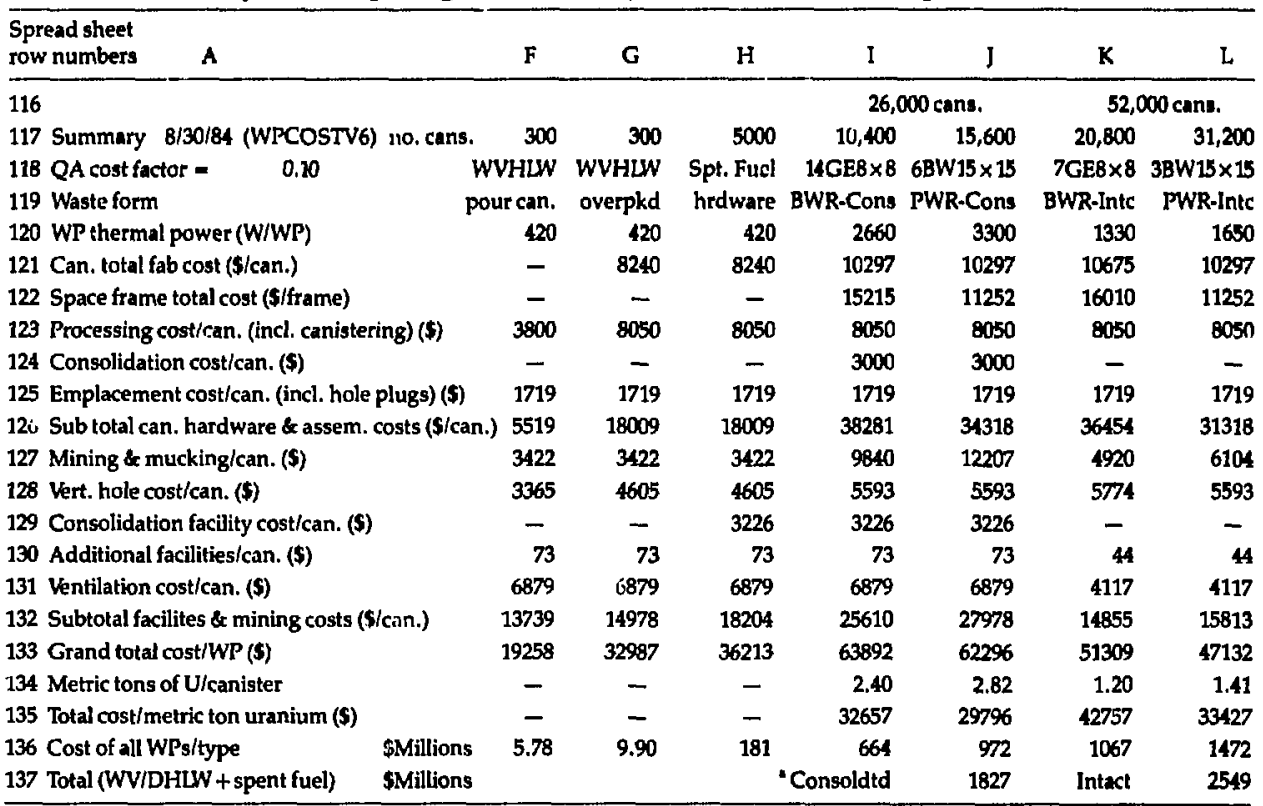

138 - Spent fuel hardware included in total consolidated cost. 
Table 17. Spread sheet printout of detailed waste package and related costs.

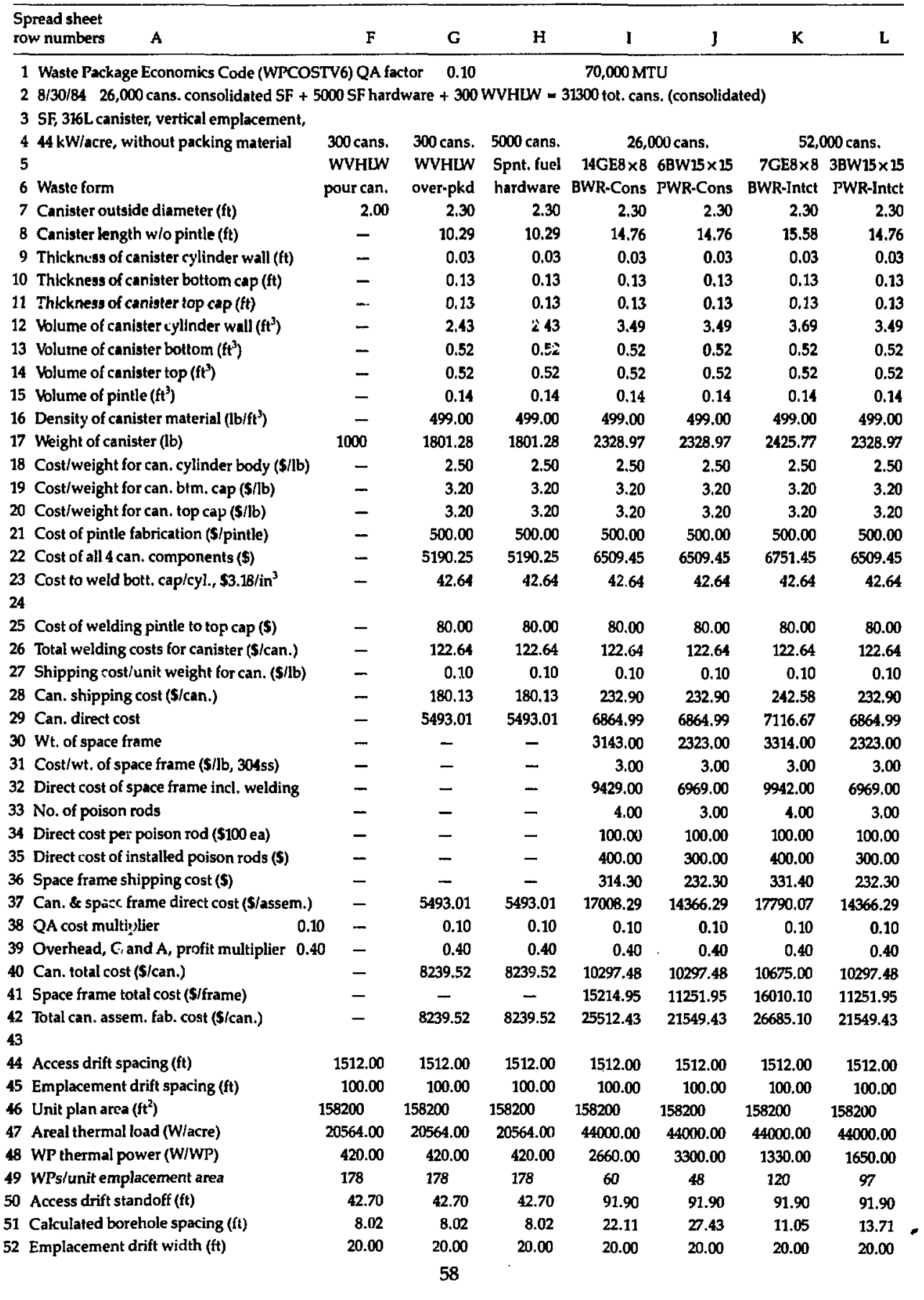


Table 17. (Continued)

\begin{tabular}{|c|c|c|c|c|c|c|c|c|c|c|}
\hline \multicolumn{2}{|c|}{$\begin{array}{l}\text { Spread sheet } \\
\text { row numbers }\end{array}$} & \multicolumn{2}{|l|}{ A } & \multirow{2}{*}{$\frac{F}{22.00}$} & \multirow{2}{*}{$\frac{G}{22.00}$} & \multirow{2}{*}{$\frac{\mathrm{H}}{22.00}$} & \multirow{2}{*}{$\frac{I}{22.00}$} & $\mathrm{~J}$ & $\mathbf{K}$ & $\therefore \mathbf{L}$ \\
\hline 53 & Emplacen & ent drift height (ft) & & & & & & .22 .00 & 22.00 & 22.00 \\
\hline 54 & E-drift vo & Ivert. hole $\left(\mathrm{ft}^{3}\right)$ & & 3530.03 & $353 \mathrm{i} .03$ & 3530.03 & 9728.07 & 12068.65 & 4864.03 & 6034.33 \\
\hline 55 & Cost/unit & ol. E-drift mined $\left(\$ / t^{3}\right)$ & & 0.88 & 0.88 & 0.88 & 0,88 & 0.88 & 0.88 & 0.88 \\
\hline 56 & E-drift mi & ing cost/vert. hole (\$) & & 3106.42 & 3106.42 & 3106.42 & 8560.70 & 10620.41 & 4280.35 & 5310.21 \\
\hline 58 & Emplacen & ent drift spacing (ft) & & 100.00 & 100.00 & 100.00 & 100.00 & 100.00 & 100.00 & 100.00 \\
\hline 59 & Access dr & $t$ width $(f t)$ & & 20.00 & 20.00 & 20.00 & 20.00 & 20.00 & 20.00 & 20.00 \\
\hline 60 & Access dr & theight (ft) & & 12.00 & 12.00 & 12.00 & 12.00 & 12.00 & 12.00 & 12.00 \\
\hline 61 & Access dr & tstand off (ft) & & 17.20 & 47.20 & 47,20 & 91.90 & 91.90 & 91.90 & 91,90 \\
\hline 62 & A-drift + & tandoff length/E-drift (f & & 265.40 & 265.40 & 265.40 & 363.80 & 363.80 & 363.80 & 36.80 \\
\hline 63 & A-drift + & tandoff vol/E-drift $\left(\mathrm{At}^{3}\right)$ & & $636 \% 6.00$ & 63696.00 & 63696.00 & 87312.00 & 87312.00 & 87312.00 & 87312,00 \\
\hline 64 & Vert. hole & E-drift & & 178 & 178 & 178 & 60 & 48 & 120 & 97 \\
\hline 65 & A-drift + & und off length/hole (ft) & & 1.49 & 1,49 & 1.49 & 6.06 & 7.51 & 3.03 & 3.76 \\
\hline 66 & A-drift + & andoff vol./hole $\left(\mathrm{ft}^{3}\right)$ & & 358.21 & 358.21 & 358.21 & 1453.40 & 1803.09 & 726.70 & 901.54 \\
\hline 67 & Cost/unit & ol. A-drift mined $\left(\mathbf{s} / \mathrm{ft}^{3}\right)$ & & 0.88 & 0.88 & 0.88 & 0.88 & 0.88 & 0.88 & 0.88 \\
\hline \multicolumn{11}{|c|}{68} \\
\hline 69 & Total A-dr & t cost/hole (\$) & & 315.22 & 315.22 & 315.22 & 1278.99 & 1586.72 & 639.49 & 793.36 \\
\hline \multicolumn{11}{|c|}{70} \\
\hline 71 & Vert. hole & lepth (ft) & & 19.84 & 20.83 & 20.83 & 25.30 & 25.30 & 26.12 & 25,30 \\
\hline 72 & Vert. hole & liameter (ft) & & 2.33 & 2.66 & 2.66 & 2.66 & 2.66 & 2.66 & 2.66 \\
\hline 73 & Vert. hole & olume $\left(\mathrm{ft}^{3}\right)$ & & 84.55 & 115.70 & 115.70 & 140.52 & 140.52 & 145.08 & 140.52 \\
\hline \multicolumn{11}{|c|}{74} \\
\hline 75 & Nc. of ver & cal boreholes & & 300.00 & 300,00 & 5000.00 & 10400.00 & 15600.00 & 20800.00 & 31200.00 \\
\hline 76 & Drill cost/ & ol. $\left(\mathbf{S} / \mathrm{ft}^{3}\right)$ & & 39.80 & 39.80 & 39.80 & 39.80 & 39.80 & 39.80 & 39.80 \\
\hline \multicolumn{11}{|l|}{77} \\
\hline 78 & Vert. hole & ost (S/hole) & & 3365.16 & 4604.74 & 4604.74 & 5592.89 & 5592.893 & 5574.16 & 5592.893 \\
\hline \multicolumn{11}{|c|}{79} \\
\hline \multicolumn{11}{|c|}{80 Summary } \\
\hline 81 & Total can. & ssem. cost (s/can.) & & - & 8239.52 & 8239.52 & 25512.43 & 21549.43 & 26685.10 & 21549.43 \\
\hline 82 & Emplacen & nt drift cost/hole & & 3106.42 & 3106.42 & 3106.42 & 8560.70 & 10620.41 & 4280.35 & 5310.21 \\
\hline 83 & Access dri & cost/hole & & 315.22 & 315.22 & 315.22 & 1278.99 & $15 \$ 6.72$ & 639.49 & 793.36 \\
\hline 84 & Wertical ho & e drilling cost (S/hole) & & 3365.16 & 4604.74 & 4604.74 & 5592.89 & 5592.89 & 5774.16 & 5592.89 \\
\hline 85 & Consolida & ion facility cost/can. & & - & - & 3225.81 & 3225.81 & 3225.81 & - & - \\
\hline 86 & Processing & costican. (incl. canisteri & & 3800.00 & 8050.00 & 8050.00 & 8050.00 & 8050.00 & 8050.00 & 8050.00 \\
\hline 87 & Consolida & ion cost/can. & & - & - & - & 3000,00 & 3000.00 & 0.00 & 0.00 \\
\hline 88 & Additiona & facilities/can. & & 73.48 & 73.48 & 73.48 & 73.48 & 73.48 & 43.98 & 43.98 \\
\hline 89 & Ventilatior & cost/can. & & 6878.59 & 6878.59 & 6878.59 & 6878.59 & 6878.59 & 4116.63 & 4116.635 \\
\hline 90 & Emplacem & nt cost/can. (ind. hole & olugs) & 1719.00 & 1719.00 & 1719.00 & 1719.00 & 1719.00 & 1719.00 & 1719.00 \\
\hline \multicolumn{11}{|c|}{91 TOTAL } \\
\hline 92 & Total cost $/$ & aste package (S/WP) & & 19257.89 & 32986.98 & 36212.79 & 63891.89 & $622 \% .00$ & 51308.72 & 47175.50 \\
\hline 93 & No. of ass & mblies & & - & - & - & 14.00 & 6.00 & 7.00 & 3.00 \\
\hline 94 & Metric ton & of U/canister & & 2.10 & 2.10 & - & 2.40 & 2.82 & 1.20 & 1.41 \\
\hline 95 & Total cost/ & nit wt. U (S/MTU) & & 9170.42 & 15708.09 & - & 26621.62 & 22090.90 & 42757.27 & 33457.80 \\
\hline 96 & Wt. of was & e per can. (lb/can.) & & 3300 & 3300 & 3000 & 8400 & 8676 & 4200 & 4338 \\
\hline 97 & Tot. wt. of & vaste package (lbs) & & 4300 & 6101 & 4801 & 13872 & 13328 & 9940 & 8990 \\
\hline \multicolumn{11}{|l|}{98} \\
\hline 99 & Total no. 0 & waste pkgs. & & 300 & 300 & 5000 & 10400 & 15600 & 20800 & 31200 \\
\hline 100 & Total can. & ssem. fab. costs & SMillions & - & 2.47 & 41 & 265 & 336 & 555 & 672 \\
\hline \multicolumn{11}{|l|}{101} \\
\hline 102 & Total proce & sing & SMillions & 1.14 & 2.42 & 40 & 84 & 126 & 167 & 251 \\
\hline 103 & Total cons & lidation & SMillions & - & - & - & 31 & 47 & - & - \\
\hline 104 & Total mini & \& mucking & SMillions & 1.03 & 1.03 & 17 & 102 & 190 & 102 & 190 \\
\hline
\end{tabular}


Table 17. (Continued)

\begin{tabular}{|c|c|c|c|c|c|c|c|c|c|}
\hline $\begin{array}{l}\text { Spread sheet } \\
\text { row numbers }\end{array}$ & A & & $\mathbf{F}$ & G & $\mathbf{H}$ & I & J & $\mathrm{K}$ & L \\
\hline \multicolumn{2}{|c|}{105 Total drilling } & SMillions & 1.01 & 1.38 & 23 & 58 & 87 & 120 & $1 \% 4$ \\
\hline \multicolumn{2}{|c|}{106 Total additional facilites } & SMillions & 0.02 & 0.02 & 0.37 & 0.76 & 1.15 & 0.91 & 1.37 \\
\hline \multicolumn{2}{|c|}{107 Total consolidation facility } & SMillions & - & - & 16 & 34 & 50 & - & - \\
\hline \multicolumn{2}{|c|}{108 Total ventilation } & SMillions & 2.06 & 2.06 & 34 & 72 & 107 & 86 & 128 \\
\hline \multicolumn{2}{|c|}{109 Total emplacement } & SMillions & 0.52 & 0.52 & 9 & 18 & 27 & 36 & 54 \\
\hline \multicolumn{10}{|l|}{110} \\
\hline \multicolumn{2}{|c|}{111 Cost of all WPs $(\cos /$ WP $\times$ no. } & Milliong & 5.78 & 9.90 & 181 & 664 & 972 & 1067 & 1472 \\
\hline \multicolumn{2}{|c|}{112 Cost of all WPs (sum of totals) } & SMillions & 5.78 & 9.90 & 181 & 664 & 972 & 1067 & 1472 \\
\hline
\end{tabular}




\section{References}

Anderson, R. T. (1982), Studies and Research Concerning BNFP: Spent Fuel S.. Iies at the Barnwell Niclear Plant, Allied General Nuclear Services, Barnwell, SC, AGNS-35900-1.1-183.

Ballou, L. B. (1983), Waste Package for a Repository in Tuff, Lawrence Livermore National Laboratory, Liver more, CA, UCRL-90044.

Baxter, R. G. (1983), Description of Defense Waste Processing Facility Reference Waste Form and Canister, E.I. du Pont de Nemours \& Co., Savannah River Plant, Aiken, SC., DP-1606, Rev. 1.

Boyd, W. A. (1983), ANO Unit I Updated Criticality Analysis, Westinghouse Nuclear Fuel Division, PGB-83029.

Brown, B. E. and J. O. Hallquist (1982), TAURUS: An Intciuctive Post-P'rocessor for the Analysis Codes NIKE3D, DrNA3D, TACO3D, and GEMINI, Lawrence Livermore National Laboratory, Livermore, CA, UCID. 19392.

Burns, Patrick J. (1982), TACO2D, A Finite Element Heat Transfer Code, Lawrence Livermore National Labora tory, Livermore, CA, UCID-17980, Rev. 2.

Davis, B. W. (1979), Convection and Thermal Radiation Analytical Models Applicable to a Nuclear Waste Repositor Room, Lawrence Livermore National Laboratory, Livermore, CA, UCID-18103.

Dravo Engineers Inc. (1984), G. Ken Beall, Ed., An Evaluution of the Effects of Horizontal and Vertical Emplacement on Mining at the Yucca Mountain Repository Site, Sandia National Laboratories, Albuquerque, NM, SAND 83-7433.

Dudley, W. W., Jr., and B. R. Erdal (1982), "'Site Characterization for Evaluation of Potential Nuclear Waste Isolation at Yucca Mountain, Nevada," Proc. of the 1982 National Waste Terminal Storage Information Meeting, DOE/NWTS-30.

Edwards, A. L. (1972), TRUMP, a Computcr Program for Transient and Steady State Temporature Distribution in Multi-Dimensional Systems, Lawrence Livermore National Laboratory, Livermore, CA, UCRL-14754, Rev. 3.

Gore, B. F., et al. (1980), Criticality Safety Considerations in the Geologic Disposal of Spent Nuclear Fuel Assemblies, Pacific Northwest Laboratory, Richland, WA, PNL-3268,.

Gregg, D. W. and W. C. O'Neal (1983), Initial Specifications for Nuclear Waste Package Extermal Dimensions and Materials, Lawrence Livermore National Laboratory, Livermore, CA, UCID-19926.

Hallquist, J. A. (1979), NIKE2D: An Implicit, Finite-Deformation, Finite Element Code for Analyzing the Staticand Dynamic Response of Two-Dimensional Solids, Lawrence Livermore National Laboratory, Livermore, CA, UCRL-52678.

Hallquist, J. O. (1982), DYNA3D Users Manual (Nonlinear Dynamic Analysis of Solids in Three Dimensions), Lawrence Livermore National Laboratory, Livermore, CA, UCID-19592.

Hallquist, J. O. (1983a), MAZE-An Input Generator for DYNA2D and NIKE2D, Lawrence Livermore National Laboratory, Lvermore, CA, UCID-19029 Rev. 2.

Hallquist, J. O. (1983b), ORION: An Interactive Post-Processor for the Analysis Codes NIKE2D, DYNA2D, and TACO2D, Lawrence Livermore National Laboratory, Livermore, CA, UCID-19310 Rev 1.

Hallquist, J. O. (1984), Users Manual for DYNA2D: An Explicit Two-Dimensional Hedrodynamic Finite Element Code with Interactive Rezoning, Lawrence Livermore National Laboratory, Livermore, CA, UCID-18756 Rev 2.

Heaberlin, S. W. and G. P. Selby (1978), Criticality Safety Comparisons of Spent Fuel Facility Concepts, Pacific Northwest Laboratory, Richland, WA, PNL-2590.

Hockman, J. N. and W. C. O'Neal (1984), Thermal Modeling of Nuclear Waste Package Designs for Disposal in Tuff, Lawrence Livermore National Laboratory, Livermore, CA, UCRL-89820, Rev 1.

Kurasch, D. H. (1980), Experimental Demonstration Program-Canister Final Design Report, Westinghouse Electric Corp. AESD, Pittsburgh, PA, AESD-TME-3047.

Lipner, M. H. and J. M. Ravets (1979), Nuclear Criticality Analyses for the Spent Fuel Handling and Pack.zging Program Demonstration, Westinghouse Advanced Energy Systems Division, WAES-TME-2928

McCright, R. D., H. Weiss, M. C. Juhas, and R. W. Logan (1983), Selection of Candidate Canister Materials for High Level Nuclewr Waste Containment, Lawrence Livermore National Laboratory, Livermore, CA, UCRL-89988.

McNair, G. W. and B. F. Gore (1980), "Feasibility of Close-Packing Fuel Rods for Geologic Di posal of Spent Fuel," Trans. Am. Nucl. Soc. 34, 406. 
Montazer, P. and W. E. MIson (1984), Conceptual Models for Flow Through the Unsaturated Zone at Yucca Mountain, Nevada, U.S. Gcological Survey, USGS-WRI-84.

Nuclear Regulatory Commission (1982), Packaging of Radioactive Maierial for Transport and Transportation of Radionctive Material Under Certain Conditions, 10 CFR Part 71.

Nuclear Regulatory Commission (1983), Disposal of High-Level Radioactive Wastes in Geologic Repositories, Technical Criteria, Final Rule, 10 CFR Part 60, Nuclear Regulatory Commission, Federal Register 48 (120).

Nevada Operations Office (1978), Safety Assessment Document for the Spent Fuel Handling and Packaging Program Demonstration at the Nevada Test Site, United States Department of Energy, Nevada Operations Office, NVO-198.

O'Brien, Paul (1984), Reference Waste Description for a Geological Repository at Yucca Mountain, Nerada, Sandia National Laboratories, A, wuquerque, NM, SAND 84-1848.

O'Neal, W. C., L. B. Ballou, D. W. Gregg, and E. W. Russell (1984), Nuclear Waste Prckage Design for the Vadose Zone in Tuff, Lawrence Livermore National Laboratory, Livermore, CA, UCRL-89830.

Oversby, V. M. (1983), Performance Testing of Waste Forms in a Tuff Environment, Lawrence Livermore National Laboratory, Livermore, CA, UCRL-90045.

Oversby, V. M. (1984), Reference Waste Forms and Packintg Materials for the Nevada Nuclear Waste Storage Intestigations Project, Lawrence Livermore National Laboratory, Livermore, CA, UCRL-53531.

Petrie, L. M., et al. (1975), KENO-IV-An Improved Monte Carlo Criticality Program, Oak Ridge National Laboratory, Oak Ridge, TN, ORNL-4938.

Roark, R. J. (1965), Formulas for Stress and Strain, Fourth Ed. (1. IcGraw Hill, New York).

Ross, W. A. and J. E. Mendel (1979), Annual Report on the Decelopment and Characterization of Solidified Forms for High-Level Wastes, Battelle Pacific Northwest Laboratory, Richland, WA., PNL-3060.

Russell, E. W., R. D. McCright, and W. C. O'Neal (1983), Containment Barrier Metals for High Level Waste Packages in a Tuff Repository, Lawrence Livermore National Laboratory, Livermore, CA, UCRL-53449.

Russell E. W. and W. C. O'Neal (1984), Structural Analysis of Conceptual Waste Package Designs for a Tuff Repository, Lawrence Livermore National Labnratory, Livermore, CA, Report (to be published).

Scully, L. W. (1983), Reference Waste Emplacement Geometries, Sandia National Laboratories, Albuquerque, NM, Keystone 5310-83-1.

Scully, L. W., R. I. Brasier, and H. F. Gram. (1983a), Econumic Impacts of Waste Emplacement Configuration for the Proposed Nuclear Waste Repository at the Nevada Test Site: Sandia National Laboratories, Albuquerque, NM, SAND83-2121C.

Scully, L. W., P. W. Eglinton, V. Stephens (LATA), B. Barnett (LATA) (1983b), Conceptual Design Guidelines for a Tuff Repository at the Nevada Test Site, Sandia National Laboratories, Albuquerque, NM, SAND831820.

Silling, S. A. (1983), Final Technical Position on Documentation of Computer Codes for High-Level Waste Management, U.S. Nuclear Regulatory Commission, NUREG-0856.

Slate, S.C., W. A. Ross, and W. L. Pertain (1981), Reference Commercial High-Level Waste Glass and Canister Description, Battelle Pacific Northwest Laboratories, Richland, WA, PNL-3838.

Southwest Engineering Enterprise (1979), Preliminary Assessment of the Thermal Effects of an Annular Air Space Surrounding an Emplaced Nuclear Waste Canister, (Southwest Engineering Enterprise, Sulphur Springs, Texas), Lawrence Livermore National Laboratory, Livermore, CA, UCRL-15014.

Stearns-Rogers Services, Inc. (1983), Cost Sensitivity Analyses NWTS Repositories in Tuff and Basalt, Denver, CO (Project C-27139).

Stein, W., J. N. Hockman and W. C. O'Neal (1984), Thermal Analysis of NNWSI Conceptual Waste Package Designs, Lawrence Livermore National Laboratory, Livermore, CA, UCID-20291.

Vieth, D. L. (1983), "Nevada Nuclear Waste Storage Investigations Project Overview," Proc. of the 1982 National Waste Terminal Storage Information Meeting, DOE/NWTS-30, 1983, pp 9-10.

Weren, B. H., M. A. Capo, and W. C. O'Neal (1983), Nuclear Criticality Safety Analysis of a Spent Fuel Waste Package in a Tuff Repository, Lawrence Livermore National Laboratory, Livermore, CA, UCRL-15575.

Westinghouse (1983), Advanced Energy Systems Division, Conceptual Waste Package Designs for Disposal of Nuclear Whaste in Tuff, Westinghouse Electric Corporation, Rept. No. ONWI-439. 